\begin{abstract}
UNIVERSIDADE DE SÃO PAULO
FACULDADE DE ECONOMIA, ADMINISTRAÇÃO E CONTABILIDADE DEPARTAMENTO DE CONTABILIDADE E ATUÁRIA

PROGRAMA DE PÓS-GRADUAÇÃO EM CONTROLADORIA E CONTABILIDADE
\end{abstract}

FABIO PEREIRA DA SILVA

\title{
OBSERVÂNCIA TRIBUTÁRIA
}

Integrando paradigmas em busca de mais conformidade fiscal

SÃO PAULO 
Prof. Dr. Marco Antonio Zago

Reitor da Universidade de São Paulo

Prof. Dr. Adalberto Américo Fischmamn

Diretor da Faculdade de Economia, Administração e Contabilidade

Prof. Dr. Gerlando Augusto Sampaio franco de Lima

Chefe do Departamento de Contabilidade e Atuária

Prof. Dr. Andson Braga de Aguiar

Coordenador do Programa de Pós-Graduação em Controladoria e Contabilidade 
FABIO PEREIRA DA SILVA

\section{OBSERVÂNCIA TRIBUTÁRIA}

Integrando paradigmas em busca de mais conformidade fiscal

Dissertação apresentada ao Departamento de Contabilidade e Atuária, da Faculdade de Economia, Administração e Contabilidade, da Universidade de São Paulo, como requisito parcial para a obtenção do título de Mestre em Ciências.

Orientador: Prof. Dr. Reinaldo Guerreiro

Versão Corrigida

(versão original disponível na Faculdade de Economia, Administração e Contabilidade)

SÃO PAULO

2015 
FICHA CATALOGRÁFICA

Elaborada pela Seção de Processamento Técnico do SBD/FEA/USP

\section{Silva, Fábio Pereira da}

Observância tributária: integrando paradigmas em busca de mais conformidade fiscal / Fábio Pereira da Silva. -- São Paulo, 2015.

$185 \mathrm{p}$.

Dissertação (Mestrado) - Universidade de São Paulo, 2015.

Orientador: Reinaldo Guerreiro.

1. Evasão fiscal 2. Observância tributária 3. Slippery slope framework 4. Paradigma do crime 5. Paradigma do serviço 6 . Análise do comportamento I. Universidade de São Paulo. Faculdade de Economia, Administração e Contabilidade. II. Título.

CDD - 364.133 
Autorizo a reprodução e divulgação total ou parcial deste trabalho, por qualquer meio convencional ou eletrônico, para fins de estudo e pesquisa, desde que citada a fonte. 
Nome: Fabio Pereira da Silva

Título: Observância tributária: integrando paradigmas em busca de mais conformidade fiscal

Dissertação apresentada ao Departamento de Contabilidade e Atuária, da Faculdade de Economia, Administração e Contabilidade, da Universidade de São Paulo, como requisito parcial para a obtenção do título de Mestre em Ciências Contábeis.

Aprovado em:

Banca Examinadora

Prof. Dr.

Instituição: Assinatura:

Prof. Dr.

Instituição: Assinatura:

Prof. Dr.

Instituição: Assinatura: 
À minha esposa, Clícia, e ao meu filho, Pedro, que são o início de uma família em que o diálogo, o companheirismo e o amor sempre irão prevalecer. 


\section{AGRADECIMENTOS}

Inicio agradecendo a todos os professores do Departamento de Contabilidade e Atuária, da FEA. Não tenho dúvida de que dele fazem parte os melhores docentes de contabilidade do país, razão pela qual foi um privilégio único estar envolvido nesse ambiente nos últimos dois anos e meio. Sou inteiramente grato, pois percebo um notório avanço no meu conhecimento científico, consequência de vivenciar esta experiência entre os melhores professores.

Contudo, não posso deixar de agradecer especificamente a todos aqueles que, de alguma forma, contribuíram para a realização desta pesquisa, com opiniões, críticas, orientações e comentários. Não foram poucos, é bem verdade. Por respeito, insegurança e autocrítica exagerada, não me furtei de pedir orientação, sempre solicitando opinião sobre a condução desta pesquisa. Por isso, meus especiais agradecimentos aos professores Reinaldo Guerreiro (meu orientador), Nelson Carvalho, Ândson Braga, Gilberto Martins, Gerlando Lima, Edgard Cornacchione, Carlos Alberto Pereira e Gustavo Vettori. Além desses, agradeço ao professor Marcelo Benvenuti, do Departamento de Psicologia da USP, por sua generosidade acadêmica, mormente para com um aluno de área completamente diversa da sua.

Injusto seria deixar de citar os professores Bruno Salotti e Fernando Dal-Ri Murcia, de cujas disciplinas tive a satisfação de participar. Obrigado pela oportunidade, pelas ótimas aulas, pela simpatia e, necessário dizer, pela paciência com minhas brincadeiras. De forma brilhante, conseguiram transformar uma matéria que para mim é de certa forma árida em um aprendizado prazeroso.

Não posso deixar de contar uma história que dá a exata noção da grandeza dos professores do departamento de contabilidade. Durante todo o primeiro ano do mestrado, troquei diversas mensagens com um professor que então se encontrava afastado de suas atividades acadêmicas na Universidade, pois ocupava, naquele momento, o cargo de Project Manager na área educacional da Fundação IFRS, em Londres. Ele chegou ao ponto de dispor de seu precioso 
tempo em pleno domingo para discutir longamente comigo, via skype, a possibilidade de minha candidatura ao "Doutorado Direto". O detalhe dessa história é que ele não me conhecia, nunca tínhamos nos encontrado e ele não sabia mais do que o fato de eu ser aluno do mestrado no departamento. A despeito de não ter qualquer obrigação nesse sentido, ele não se furtou de se dedicar nem mesmo quando o assunto se referia a uma angústia pessoal sobre ser ou não a decisão correta me candidatar ao "Doutorado Direto". Professor Guillermo Braunbeck, nenhuma palavra que eu possa proferir neste espaço estaria à altura de sua generosidade. De todo modo, receba meu singelo agradecimento e meu respeito incondicional.

Especial menção faço ao professor Erick Kirchler, da Universidade de Viena, cuja obra é sem dúvida a maior inspiração desta dissertação. Não bastasse a qualidade de suas pesquisas, o professor Erick foi extremamente solícito para comigo, respondendo meus e-mails e, vejam só, franqueando acesso a todos os seus estudos, inclusive aqueles em desenvolvimento. Fiquei realmente encantado com tamanha simpatia, sendo indispensável o agradecimento.

Encerrando os agradecimentos aos docentes, a gratidão também não cabe em palavras quando me refiro aos meus ex-professores Roberto Sousa Gonzales, Víctor Damato e Paulo Cordeiro de Melo. Além de me aturarem como aluno (quem me deu aula sabe a exata noção do que isso significa), ainda me abriram as portas, possibilitando a coleta de dados sem a qual esta pesquisa não seria possível. Meu muito obrigado aos três, que deve ser estendido ao Fernando Trevisan, que autorizou a coleta.

Agradeço aos meus colegas de mestrado, que me obrigaram a muito esforço para eu poder diminuir a distância entre minha modesta sabedoria e a de todos eles. Termino o mestrado absolutamente impressionado com a capacidade de cada um, certo de que terão carreiras brilhantes pela frente e grato por terem me proporcionado esta oportunidade singular. Espero reencontrá-los em breve e com frequência. 
Meus agradecimentos também vão a toda a equipe da WS Advogados. Não fosse o esforço de cada um deles, suprindo minha ausência no dia a dia das atividades do escritório, e este momento não seria possível. Agradecimento especial aos meus sócios, Rodolfo Weigand e Estácio Aírton, que precisaram se desdobrar durante todo esse período. Não posso esquecer ainda de agradecer ao Alexandre Rossi, que, além da colaboração nas atividades diárias do escritório, teve paciência para ouvir minhas lamentações, aguentar meu stress e até mesmo opinar sobre este estudo. Chamar-Ihe de apenas amigo não faria jus à nossa relação fraternal.

Quero aqui ainda me referir com carinho ao meu antigo sócio Sergio Galvão de Souza Campos, a quem sou grato por ele nunca ter deixado de me estimular nos meus estudos. Foi quem me proporcionou as primeiras oportunidades na carreira jurídica, e a ele serei eternamente grato.

Minha família, como não podia deixar de ser, ocupa uma parte especial nesse processo. Meu agradecimento emocionado à minha irmã, Luciana, que não posso restringir a qualquer questão acadêmica. Refiro-me, agora, a absolutamente tudo. Aos meus pais, os agradecimentos são feitos em meio a lágrimas. Vocês são meus heróis. Tudo isso é consequência do esforço de vocês, e estejam certo de que o netinho que está chegando e outros que virão também terão o mesmo privilégio, pois eu tenho um bom espelho. Amo vocês!

Agradeço ao meu sogro, Milton pelas conversas, críticas, broncas, palavras de sabedoria e trocas de experiência, que sempre ajudaram a me manter de cabeça firme e focada no objetivo.

Por fim, minha esposa, Clícia Giannelli! Agradecer a ela não seria justo. Nem que eu usasse um capítulo todo. Certo seria que o diploma do mestrado viesse em seu nome, tamanho foi seu esforço e dedicação. Esteve ao meu lado em todos os momentos, sem fraquejar. Aguentou pacientemente minha dedicação quase que exclusiva aos livros. Aceitou com bondade minha ausência física e, muitas vezes, psíquica. Como diz a canção, soube me abraçar quando eu estava triste e se afastar quando eu estava louco. Todo o meu amor não é suficiente para lhe 
agradecer. Ela merece o título de mestre tanto ou até mais do que eu, pois sem ela este desafio não seria superado. Muito mais que amor é o que eu sinto por ela!

O mestrado foi uma longa e difícil caminhada. Só quem já passou por isso consegue ter alguma medida daquilo a que estou me referindo. Há momentos em que a gente se desespera, perde a vontade, chora, se estressa, pensa em desistir. A gente continua, porque sabe que ao final valerá a pena. Hoje eu sei que não é bem assim. É muito mais. Não se trata de o final valer a pena. O que valeu a pena foi a caminhada. O que conclui o mestrado em 2015 é diferente daquele Fabio que começou o mestrado no início de 2013. Não há título no mundo que se compare às experiências que vivenciei; ao crescimento pessoal que passei. A todos que participaram desta viagem, meu eterno agradecimento.

Ah... Pedro... papai te ama. Pode vir, que estou pronto! 
Boas pessoas não precisam de leis para obrigá-las a agir responsavelmente, enquanto as pessoas ruins encontrarão um modo de contornar as leis.

Platão 


\section{RESUMO}

Silva, F. P. (2015). Observância tributária: integrando paradigmas em busca de mais conformidade fiscal. Dissertação de Mestrado, Programa de Pós-graduação em Controladoria e Contabilidade, Universidade de São Paulo, São Paulo.

A pesquisa sobre observância tributária floresceu no campo econômico, tendo como estudos seminais as obras de Allingham e Sandmo (1972) e Srinivasan (1973). Esses artigos basearam-se na teoria de Becker (1968) sobre crime e punição, aceitando o paradigma econômico clássico, que parte do pressuposto de que os indivíduos adotam comportamentos racionais. Nas últimas décadas, contudo, muitos pesquisadores notaram que esse paradigma, do qual derivou aquilo que veio a ser chamado pela academia de "paradigma do crime", explicava apenas parcialmente o comportamento do contribuinte. Surge, então, toda uma linha de pesquisa contrapondo esse paradigma racional, partindo da constatação de que o comportamento do contribuinte é muito mais complexo do que inicialmente se supunha, merecendo uma análise multidisciplinar, ou seja, que não se restrinja ao campo econômico, mas que também abarque outras disciplinas. Esse novo paradigma foi denominado pela academia de "paradigma do serviço" que, em linhas gerais, contempla outros fatores envolvidos no ato de pagar tributos, inclusive psicológicos, pressupondo, de tal modo, que o contribuinte não é um indivíduo racional unicamente preocupado em maximizar sua utilidade, devendo ser visto pela administração pública como uma espécie de cliente, e recebendo tratamento adequado e serviços públicos de qualidade em contrapartida ao cumprimento de suas obrigações tributárias. O presente estudo faz uma apreciação dos dois paradigmas, introduzindo nessa avaliação conceitos da ciência denominada Análise do Comportamento, cujos ensinamentos sobre a aprendizagem e o comportamento humano têm o potencial de contribuir de forma significativa para o entendimento do assunto. Testando os pressupostos teóricos apresentados no decorrer do trabalho, foram realizados dois estudos empíricos, tomando-se como base o modelo criado pelo pesquisador e psicólogo Erich Kirchler, denominado Slippery Slope Framework, que confirma estudos anteriores e demonstra que tanto punições quanto recompensas são instrumentos eficazes no combate à evasão fiscal, sugerindo que a integração dos paradigmas "do crime" e "do serviço", bem como a inserção dos princípios da Análise do Comportamento nesta análise é um caminho promissor no combate à evasão fiscal.

Palavras-chave: Evasão fiscal. Observância tributária. Slippery Slope Framework. Paradigma do crime. Paradigma do serviço. Análise do Comportamento. 


\begin{abstract}
Silva, F. P. (2015). Tax compliance: integrating paradigms seeking more tax compliance. Master's Degree Dissertation, Graduate Degree Program in Controllership and Accounting, University of São Paulo, São Paulo.

Research on tax compliance has arisen in the economic field with seminal studies based upon the works of Allingham and Sandmo (1972) and Srinivasan (1973). Such articles were based on Becker's theory (1968) on crime and punishment, accepting the classic economic paradigm, which presupposes that individuals show rational behaviors. Nevertheless, in the past decades, many researchers have noticed that such paradigm, which gave rise to what is referred to, by the academy, as "crime paradigm", explained the behavior of taxpayers solely in part, and an entire line of research opposing such rational paradigm arose, based upon the verification that the behavior of taxpayers is much more complex than what was originally presumed, deserving a multidisciplinary analysis, i.e., not restricted to the economic field, but that, further, encompasses other subjects. Such new paradigm was designated by the academy as "service paradigm" that, in general, contemplates other factors involved in the act of paying taxes, including psychological factors, thus presupposing that taxpayers are not rational individuals solely concerned about maximizing the function thereof, they should be deemed, by the public administration, to be clients, and should receive appropriate treatment and quality public services in return for complying with their tax obligations. This study analyzes two paradigms, introducing in such analysis concepts of the science called Behavior Analysis, the teachings on learning and human behavior of which have potential to significantly contribute to better understanding the subject. Testing the theoretical assumptions presented throughout the study, two empirical analyses were conducted, based upon the model created by researcher and psychologist Erich Kirchler, referred to as Slippery Slope Model, which confirms previous studies and indicates that both punishment and reward are effective tools to fight against tax evasion, suggesting that integrating "crime" and "service" paradigms and inserting concepts of the Behavior Analysis Science in this analysis is highly promising to fight against tax evasion.
\end{abstract}

Key-words: Tax evasion. Tax compliance. Slippery Slope Framework. Crime paradigm. Service paradigm. Behavior Analysis. 


\section{LISTA DE TABELAS}

Tabela 1 - Análise descritiva da variável idade 130

Tabela 2 - Distribuição da amostra quanto às variáveis sexo, escolaridade, grupo e Estado.

Tabela 3- Distribuição das observações em cada etapa de aplicação de filtro de exclusão.

Tabela 4 - Distribuição das respostas às questões Q1 a Q14 no tocante a observância fiscal. 133

Tabela 5 - Manova para observância voluntária. 134

Tabela 6 Manova para observância forçada. .135

Tabela 7 - Análise descritiva das questões para cada variável estudada .135

Tabela 8 - Análise fatorial para observância voluntária. 136

Tabela 9 - $\quad$ Anova para observância voluntária (fator $1+4)^{2}$ 137

Tabela 10 - Média do fator 1 a partir das questões .137

Tabela 11 - Análise fatorial para observância forçada.........................................................138

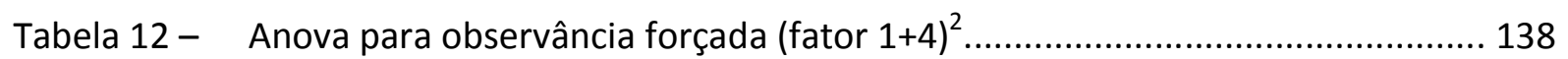

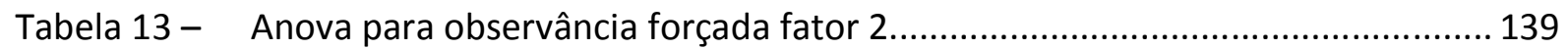

Tabela 14 - Médias dos fatores 1 e 2 obtidos a partir das questões de compliance forçado para as categorias força, confiança e confiança*força.

Tabela 15 - Análise descritiva da variável valor médio de imposto pago (10 períodos) nas categorias confiança, força e confiança*força. 140

Tabela 16 - Anova da variável valor médio de imposto pago como variável dependente quantos aos fatores independentes confiança, força, confiança*força e às variáveis de controle sexo e idade.

Tabela 17 - Comparações múltiplas de Tukey para efeito da interação no valor médio do imposto pago. 141

Tabela 18 - Distribuição da amostra quanto ao grupo de tratamento e sexo. 147

Tabela 19 - Efeito do tratamento para cada grupo. 149 
Tabela 20 - Comparação entre os grupos no momento anterior ao tratamento 150

Tabela 21 - Comparação entre os grupos no momento posterior ao tratamento 151

Tabela 22 - Comparações múltiplas de Tukey para diferenças entre os grupos no momento posterior ao tratamento

Tabela 23- Análise de variância para diferenças entre os grupos no efeito do tratamento. 151

Tabela 24 - Comparações múltiplas de Tukey para diferenças entre os grupos na diferença de pagamento de imposto entre os momentos anterior e posterior (depois antes). 151

Tabela 25- Teste de Kruskal-Wallis para comparação entre os três grupos de tratamento. 152

Tabela 26 - Comparações múltiplas de Dunn para diferenças entre os grupos no momento anterior e posterior (depois-antes). 152

Tabela 27 - Comparações múltiplas de Dunn para diferenças entre os grupos na diferença de pagamento de imposto entre os momentos anterior e posterior (depoisantes). 153 


\section{LISTA DE FIGURAS}

Figura 1 - Ciclo vicioso do aumento do rigor das punições.............................................. 59 


\section{LISTA DE GRÁFICOS}

Gráfico 1 - Slippery Slope Framework do comportamento de observância fiscal..... 105

Gráfico 2 - Curva do comportamento do pagamento de imposto médio ao longo do tempo Grupo Controle...

Gráfico 3 - Curva do comportamento do pagamento de imposto médio ao longo do tempo -

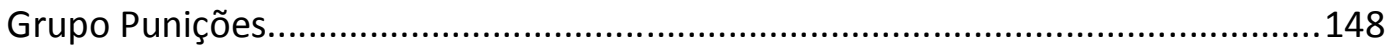

Gráfico 4 - Curva do comportamento do pagamento de imposto médio ao longo do tempo -

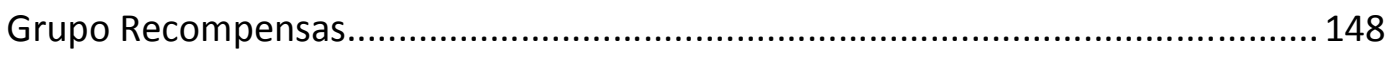

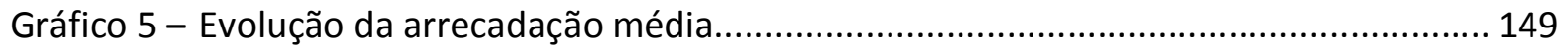




\section{LISTA DE SIGLAS E ABREVIATURAS}

Ancova: Análise de Covariância

Anova: Análise de Variância

FEA: $\quad$ Faculdade de Economia, Administração e Contabilidade

Mancova: Análise de Covariância Multivariada

Manova: Análise de Variância Multivariada

USP: $\quad$ Universidade de São Paulo 



\section{SUMÁRIO}

1 INTRODUÇÃO

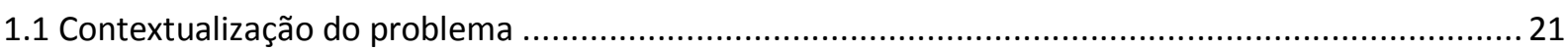

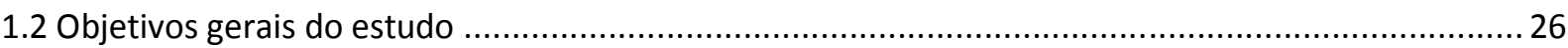

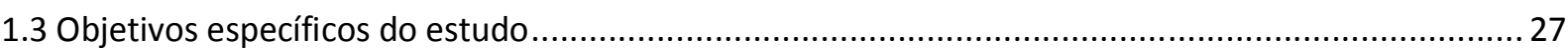

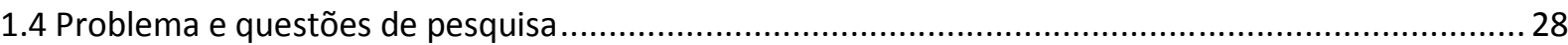

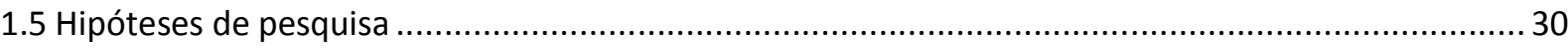

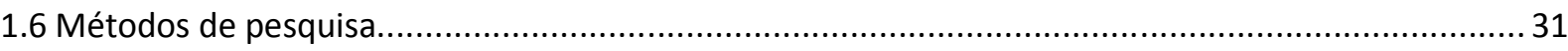

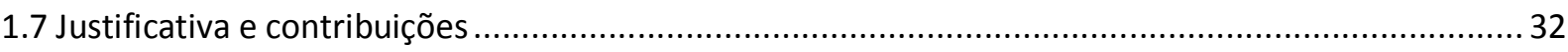

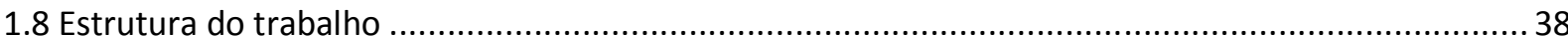

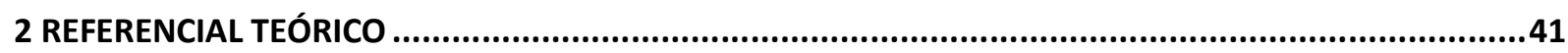

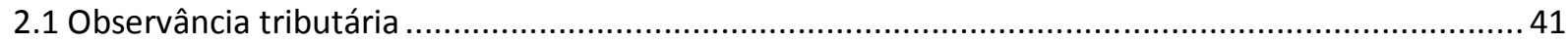

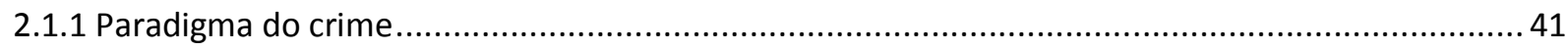

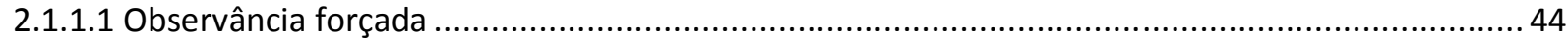

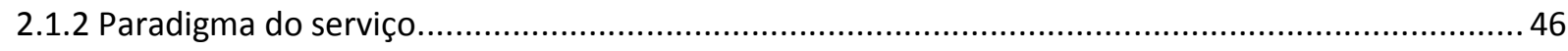

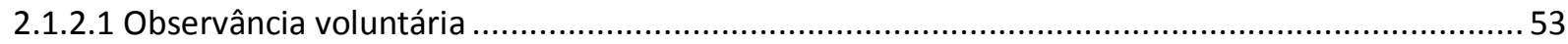

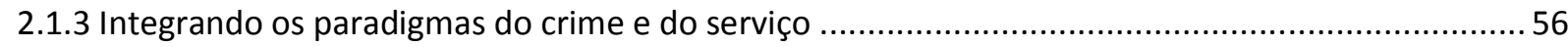

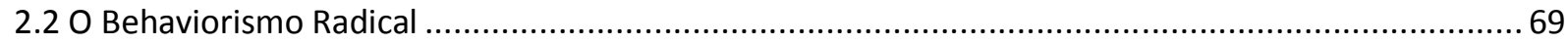

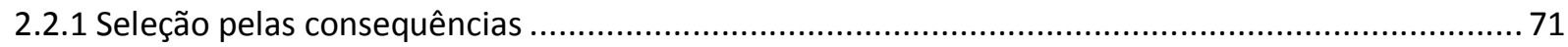

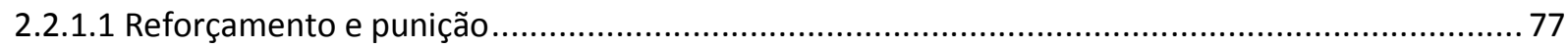

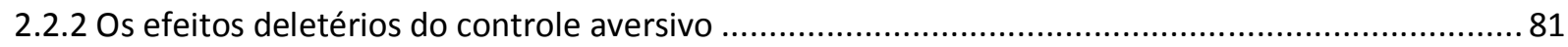

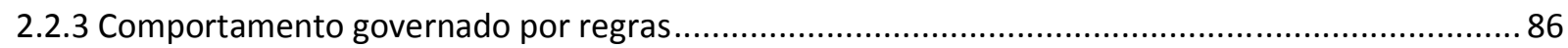

2.30 aprendizado por consequência e os paradigmas do crime e do serviço..........................................90

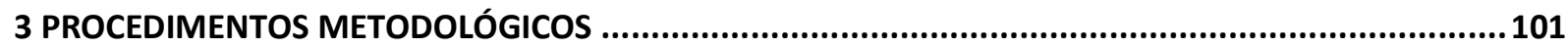

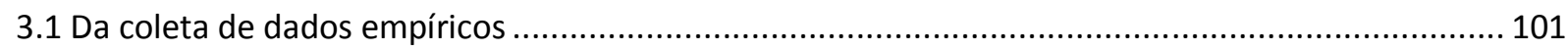

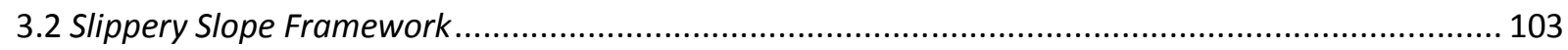

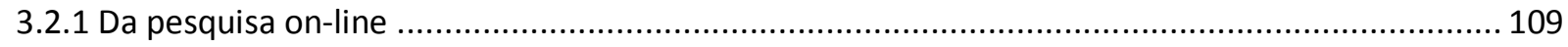

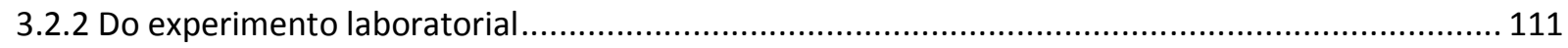

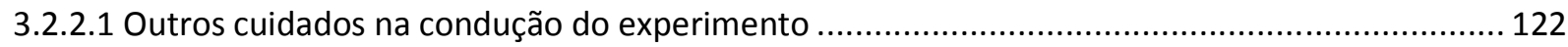

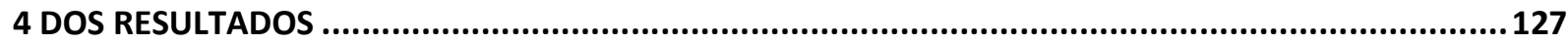

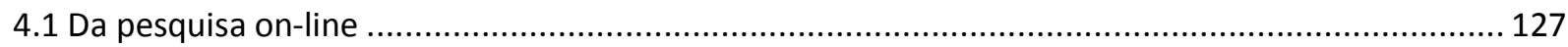




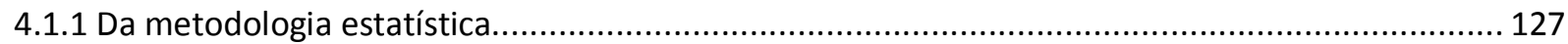

4.1.2 Da apresentação dos resultados ........................................................................ 130

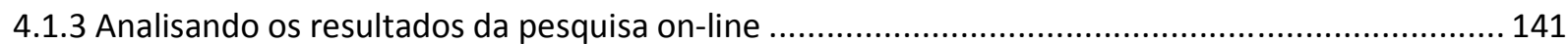

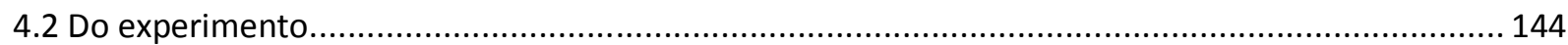

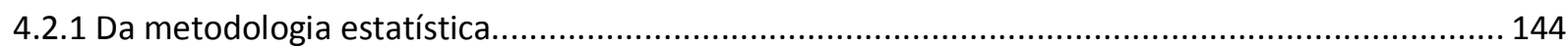

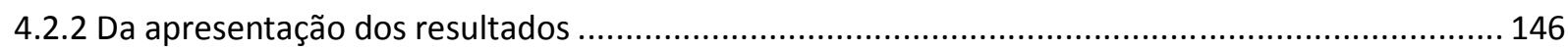

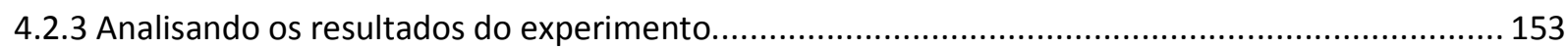

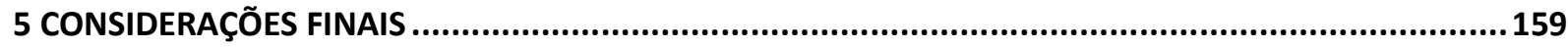

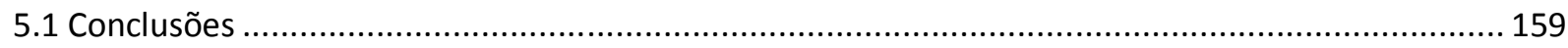

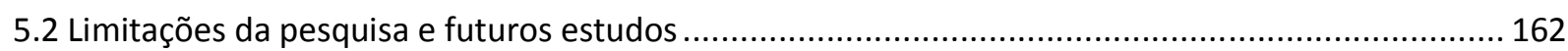

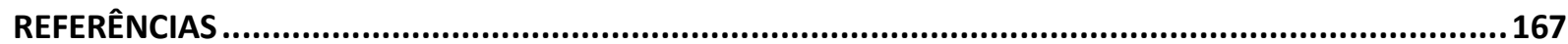

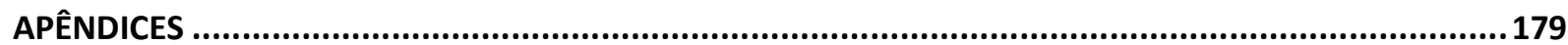




\section{INTRODUÇÃO}

\subsection{Contextualização do problema}

É seguro dizer que apenas em período relativamente recente o estudo de temas relacionados à observância fiscal ${ }^{1}$ passou a ocupar a mente de pesquisadores de maneira significativa, conforme sugerem Alm, McClelland e Shulze (1992b), Kirchler (2007) e Murray (1995). Não por coincidência, a inquietação sobre esse assunto vem evoluindo de forma gradual, na medida em que o peso dos tributos vai, paulatinamente, afetando o dia a dia dos cidadãos.

Nota-se, especialmente, que a adoção por algumas jurisdições de um modelo econômico de bem-estar social, com presença mais significativa do Estado na vida das pessoas, exigiu um padrão de arrecadação tributária mais agressivo, de modo que a observância fiscal passou a preocupar indistintamente todos os setores sociais. A academia, nesse passo, soube absorver essa demanda, ocupando-se do estudo do tema de forma mais expressiva.

Assinale-se, nessa toada, que não apenas a quantidade de pesquisas sobre o assunto apresentou crescimento exponencial, mas, igualmente, os paradigmas adotados nos estudos modificaram-se com o passar dos anos, como Alm (1991) previa ser necessário. Não é despropositado afirmar que essa mudança de paradigmas é causa e, por que não, consequência da aplicação de uma abordagem multidisciplinar que vem sendo notada na condução das pesquisas, em contraposição ao que ocorria antigamente, quando predominava o enfoque econômico clássico.

De início, a maioria dos estudos referentes à prática de sonegação fiscal floresceram no campo econômico e repousavam unicamente em uma suposta racionalidade econômica dos

\footnotetext{
${ }^{1}$ Neste estudo, observância tributária e observância fiscal são expressões empregadas como tradução livre de tax compliance. Ademais, o termo não se refere aos aspectos macroeconômicos fiscais, mas tão somente as questões relacionadas à arrecadação tributária.
} 
indivíduos. No entanto, como dito acima, nas últimas décadas novos paradigmas foram assumidos e o tema se tornou relevante objeto de pesquisa, envolvendo uma abordagem multidisciplinar (Kastlunger, Müehlbacher, Kirchler, \& Mittone, 2011), abarcando não só a economia, mas também a contabilidade, o direito, a política, a sociologia e, em particular, a psicologia (Kirchler, Kogler, \& Müehlbacher, 2014).

A evolução desse paradigma é notável quando se avalia de forma ampla a pesquisa acadêmica sobre observância tributária. Dois artigos científicos seminais são considerados pela academia o "pontapé inicial" de diversos estudos relevantes sobre o tema (Allingham \& Sandmo, 1972; Srinivasan, 1973). Esses estudos basearam-se na teoria de Becker (1968) sobre crime e punição, aceitando integralmente o paradigma econômico clássico, segundo o qual os indivíduos adotam comportamentos racionais, de maneira que, no caso dos contribuintes, a decisão entre o recolhimento e a sonegação dos tributos resulta da avaliação entre o benefício financeiro e o risco de ser auditado e, consequentemente, punido. Desse modo, os autores avaliam que quanto maior for o risco de ser auditado pelas autoridades e a severidade da punição, maior será a tendência de o contribuinte agir honestamente.

Inicialmente, esse paradigma utilitarista foi aceito pela academia sem grandes controvérsias, gerando toda uma linha de pesquisa com base nesses seminais estudos. Durante anos, o que se viu foi a produção de pesquisas empíricas visando testar ou aperfeiçoar os modelos propostos.

Com o desenvolvimento da pesquisa sobre o tema, porém, notou-se que o paradigma econômico racional não explicava ou explicava apenas parcialmente o comportamento do contribuinte. Dentre diversos autores importantes que se aperceberam desse fato, um dos mais influentes é o economista americano James Alm, cuja vasta obra sobre o tema é referência mundial. Em seus estudos, junto com outros autores, esse pesquisador soube resumir com maestria a limitação do paradigma econômico clássico, ao constatar que a probabilidade de ser auditado é mínima, embora grande parte da população mundial cumpra suas obrigações fiscais, 
o que o levou a concluir, sabiamente, que outros fatores envolvem a decisão do contribuinte, e não apenas o desejo de maximizar seu retorno econômico (Alm \& Torgler, 2011; Alm et al., 1992b; Alm et al., 2012b).

A propósito, Alm et al. (2012b) afirmam que se o risco de ser auditado fosse a única razão da decisão de sonegar tributos, então nos locais onde essa probabilidade fosse reduzida os contribuintes não declarariam qualquer renda, optando pelo benefício financeiro individual, o que, na prática, não se confirma.

Os autores, inclusive, citam outras descobertas científicas e reverberam que distintas motivações influenciam a decisão do contribuinte de pagar seus tributos. A noção de culpa, moralidade, vergonha, altruísmo, além de questões que não se restringem apenas ao indivíduo, como normais sociais, justiça, confiança, reciprocidade, moralidade fiscal e patriotismo, afetam a decisão do indivíduo, contrariando o paradigma econômico clássico. De forma semelhante, Alm e Torgler (2011) entendem que o contribuinte não pode ser visto tão-somente como um indivíduo egoísta, racional e interessado apenas no próprio benefício, sendo seu comportamento também influenciado por padrões éticos.

Outra questão relevante que infirma o paradigma da decisão individual e racional do contribuinte é o reconhecimento da existência de outros atores que influenciam a sua disposição para pagar tributos, noção que tem sido deixada a par dos debates sobre o tema, mormente no cenário nacional. A interação desses atores afeta o comportamento do indivíduo e tem grande importância na análise da prática de sonegação fiscal (Leviner, 2008). O modo como cada um deles age no contexto social e como eles interagem afeta a decisão individual referente à obrigação tributária.

Há que se reconhecer, consequentemente, a existência de uma intricada inter-relação dos diversos atores, como é o caso do Governo, autoridades, contadores, advogados e contribuintes, que deve ser considerado quando da análise da prática de sonegação fiscal. É a 
interação desses elementos no ambiente fiscal, em especial a dinâmica entre poder e confiança que os envolvem, que o Estado da Arte da pesquisa sobre o tema revela como novo paradigma de estudo (Alm et al., 2012b; Kirchler, 2007).

Em virtude dessa constatação, Alm et al. (2012b) e Kirchler (2007) citam que o Governo influencia os níveis de sonegação fiscal, através da transparência das leis e do dispêndio escorreito dos valores arrecadados. As autoridades fiscais, ao seu turno, exercem mandato no sentido de garantir a observância fiscal, porém a percepção dos contribuintes acerca da legitimidade do poder emanado dessas autoridades e a confiança que sentem no Governo são fatores que influenciam suas decisões. Os contadores, tais quais os advogados, muitas vezes atuam como elo entre as autoridades e os contribuintes, inclusive com o propósito de avaliar a legislação no sentido de reduzir, legalmente, a carga tributária que recai sobre seus clientes. Por fim, o indivíduo também é afetado pela decisão dos outros contribuintes, provavelmente por uma questão de justiça social, em que cada um colaboraria com sua cota-parte em favor da coletividade. Como consequência, a inter-relação e a interação de todos esses atores afeta os níveis de observância fiscal de determinada região ou país, demonstrando que o tema é muito mais complexo do que inicialmente se supunha.

Em linhas gerais, haveria uma espécie de contrato psicológico envolvendo todos esses atores, em especial entre contribuintes, Governo e autoridades. Alm et al. (2012b) e Kirchler (2007) afirmam que, havendo um clima de confiança nessa interação, os cidadãos estarão mais propensos ou sensíveis ao pagamento de seus tributos, criando-se um ambiente de cooperação recíproca. De outra ponta, o poder exercido pelas autoridades também seria fonte de influência no comportamento escorreito dos contribuintes, bem como pode afetar o nível de confiança, sendo o contrário igualmente verdadeiro.

Portanto, esse paradigma traz à baila a interação dos contribuintes com o Governo e as autoridades, evidenciando que o indivíduo é afetado por essa inter-relação, o que influencia o nível de observância. Segundo Kirchler (2007), disso podem resultar dois diferentes tipos de 
clima fiscal. O primeiro deles seria um ambiente policialesco, no qual o contribuinte é tratado pelas autoridades como um potencial criminoso, sempre disposto a encontrar alternativas para inadimplir suas obrigações tributárias, motivo pelo qual a acadêmia convencionou nomeá-lo como "paradigma do crime", baseado primordialmente em uma suposta racionalidade econômica dos cidadãos, em linha com os estudos de Allingham e Sandmo (1972) e Srinivasan (1973). Para evitar a evasão fiscal, nesse caso, as autoridades focam seus esforços em auditorias e aplicação de sanções.

Em oposição, o autor assinala haver quase que uma relação de clientela entre contribuintes e autoridades, ou seja, um ambiente baseado no serviço, em que o primeiro é tratado como um verdadeiro cliente pelo segundo, contribuindo através do pagamento de tributos e, em troca, recebendo contraprestação em serviços de qualidade e tratamento adequado. Esse intercâmbio profícuo entre ambos os lados cria um clima de cooperação que, como consequência, reduz a inadimplência tributária. O combate à evasão, nessa abordagem, dá-se através do aumento da qualidade dos serviços ofertados, da interação respeitosa das partes e do tratamento equânime dos contribuintes, no qual as autoridades procuram orientálos em direção ao cumprimento das normas, e não apenas puni-los como se criminosos fossem.

Surge, como consequência, um novo paradigma, denominado "paradigma do serviço", que se contrapõe ao paradigma econômico racional clássico. Segundo essa nova abordagem, o comportamento do contribuinte é influenciado por outros fatores que não apenas o desejo de maximização da utilidade individual, envolvendo uma extensa gama de motivações, em especial o clima advindo da interação das partes envolvidas nos assuntos tributários.

Paralelamente a isso, notou-se em diversos países, em especial nos Estados Unidos, um aumento na utilização da política chamada de stick and carrots, cuja tradução literal remete a"porrete e cenoura", que se consubstancia na implementação de políticas fiscais envolvendo sanções e recompensas, com o objetivo de aumentar o nível de conformidade tributária por parte dos contribuintes. $\mathrm{O}$ analista mais atento naturalmente associa essas práticas aos 
ensinamentos do psicólogo americano Burrhus Frederic Skinner, responsável pelo desenvolvimento de toda uma teoria sobre a aprendizagem por consequência, baseados em intensos e pioneiros experimentos.

Curiosamente, contudo, são raros os estudos sobre observância tributária em que Skinner seja citado, o que chamou a atenção de Kirchler (2007), para quem as teorias e lições do festejado psicólogo têm o potencial de contribuir para o entendimento do tema, motivo de sua surpresa com a escassez de menções ao referido estudioso nas pesquisas sobre o assunto.

Diante desse cenário, a presente dissertação propõe a realização de estudo cujo objetivo é avaliar as duas vertentes principais sobre o tema observância fiscal, e que representa, atualmente, o Estado da Arte no campo científico envolvendo esse assunto, procurando-se contrapor os denominados "paradigma do crime" e "paradigma do serviço", levando em conta a interação de Governo, autoridades e contribuintes envolvidos nesse processo. Adicionalmente, o estudo abordará a ciência do comportamento denominada Análise do Comportamento, especialmente os ensinamentos de Skinner, cuja inserção no estudo do tema tem potencial para contribuir para o entendimento mais amplo do assunto.

Através deste estudo, e junto com a análise dos resultados da pesquisa empírica, pretende-se fornecer elementos para o debate sobre as políticas fiscais praticadas no país e colaborar para o entendimento do modo como o contribuinte se comporta, cujo objetivo final deve ser sempre, ainda que indiretamente, aumentar a conformidade fiscal, por meio do desestímulo a condutas evasivas.

\subsection{Objetivos gerais do estudo}

Dada a complexidade do tema abordado no presente estudo, utópico seria pretender esgotá-lo. Não se trata de estudo definitivo, mas apenas uma contribuição que objetiva fornecer alguns elementos ao debate acerca da prática de sonegação fiscal no Brasil e às 
políticas adotadas para combater esse fenômeno social. Impende alertar que muito se discute no país sobre carga tributária e reforma fiscal, porém, pouco se debate sobre o comportamento dos contribuintes em resposta às práticas adotadas pelos governantes. Como consequência, uma gama de políticas fiscais é posta à prova à margem de uma avaliação mais rigorosa sobre suas consequências e influências no comportamento do contribuinte, em especial no longo prazo.

Com base na análise da evolução da pesquisa científica sobre o tema, bem como dos resultados empíricos obtidos neste estudo, objetiva-se aumentar a compreensão dos fatores que envolvem a observância fiscal e como diferentes tipos de abordagens e práticas afetam o comportamento do contribuinte, fornecendo alguns aspectos pertinentes que venham a contribuir para um debate mais abrangente sobre política fiscal. Através da discussão de tema tão complexo, será possível tentar avaliar caminhos alternativos para a redução da sonegação fiscal.

\subsection{Objetivos específicos do estudo}

De modo específico, pretende-se testar e confrontar os resultados obtidos pela aplicação em outros países do framework criado pelo pesquisador Erich Kirchler, da Universidade de Viena, denominado Slippery Slope Framework, objeto de explicação detalhada ao longo do presente estudo. A comparação de resultados é importante para o amadurecimento da pesquisa sobre observância tributária e o entendimento dos fatores que afetam o comportamento do contribuinte, além de aumentar a validade dos achados.

Através da utilização desse framework, é possível avaliar se o grau de confiança dos contribuintes no Governo e a sua percepção do poder de coerção exercido pelas autoridades fiscais afetam o nível de observância fiscal voluntária e forçada, possibilitando uma melhor compreensão e avaliação do "paradigma do crime" e do "paradigma do serviço". Essa análise é fundamental para um sistema tributário que pretenda ser eficiente, especialmente 
considerando-se que a observância voluntária do contribuinte dispensaria os altos investimentos que são necessários para a garantia de uma observância forçada, de modo a proporcionar uma melhor alocação de recursos em favor do sistema.

Na sequência, faz parte da segunda etapa da análise empírica, contida no estudo, a avaliação de como o contribuinte nacional reage aos modelos de política tributária que se baseiam em sanções para aqueles que descumprem a lei e recompensas efetivas e potenciais que possam reforçar positivamente o comportamento daquele que obedece à legislação fiscal, tendo como base os ensinamentos de Skinner e da Análise do Comportamento Humano.

Os resultados de ambas as etapas fornecerão elementos para o entendimento de como o contribuinte brasileiro se comporta quando confrontado com determinado ambiente e situações, que serão objeto de questionário ou simuladas experimentalmente.

\subsection{Problema e questões de pesquisa}

Conforme mencionado em tópico precedente, o comportamento do contribuinte e os fatores que o influenciam são demasiadamente complexos, sendo utópica, e exigindo esforço hercúleo, qualquer pretensão no sentido de compreender integralmente o ato de pagar ou sonegar tributos.

A par dessa constatação, a academia evoluiu consideravelmente no sentido de contribuir para o entendimento do tema, senão de maneira integral, ao menos de forma mais abrangente do que os primórdios da pesquisa possibilitaram através da aplicação tão-somente do paradigma econômico clássico.

Sendo o comportamento do contribuinte envolvido em intensa complexidade, somente através da aplicação de abordagem multifacetada, que busque um entendimento mais amplo 
do assunto, será possível obter resultados que possibilitem a evolução da pesquisa científica sobre observância fiscal.

Inegavelmente, a pesquisa desse tema constitui imenso desafio, já que sua avaliação traz à tona diversas questões intricadas, destacando-se, apenas para exemplificar, as seguintes: Quais principais fatores influenciam o comportamento dos contribuintes? É possível as autoridades controlarem esse comportamento? De que modo, e com que efetividade? Somente através de forte presença das autoridades, o contribuinte obedecerá à lei, ou haverá oportunidades em que isso ocorrerá voluntariamente? As consequências são vetores que propiciam o aprendizado e o aumento da conformidade?

Diante de uma grande variedade de questionamentos sobre o assunto, surgem, naturalmente, muitas respostas de senso comum para justificar a evasão fiscal, em especial no Brasil, como, por exemplo: injustiça fiscal, falta de contraprestação por parte do Governo, alta carga tributária, complexidade da legislação, ausência de educação cívica e desníveis regionais. Ocorre que a busca por fatores individuais que motivam a sonegação fiscal mostra-se claudicante, pois a análise mais detida das pesquisas sobre o tema contradiz o senso comum ou apresenta resultados antagônicos.

De se assinalar ainda que as respostas do senso comum não condizem com a importância do assunto, sendo aconselhável o emprego de método científico em busca de respostas mais rigorosas. Nesse sentido, Cozby (2003) sustenta a utilidade de se testar tais ideias, visto que os resultados podem demonstrar que o mundo real é bem diferente do que o senso comum levaria a supor.

Dessa forma, e em alinhamento com os objetivos gerais e específicos anteriormente traçados, apresentam-se, a seguir, duas questões de pesquisa que se pretende responder ao final do estudo, após análise dos resultados: 
Q1 - De que modo a interação entre contribuintes, autoridades fiscais e Governo afeta o comportamento dos primeiros?

Q2 - Quais as principais consequências da implementação de políticas públicas baseadas em punições e recompensas na busca por mais observância fiscal?

\subsection{Hipóteses de pesquisa}

Seguindo os objetivos delimitados pelo estudo, apresentam-se três hipóteses metodológicas que serão testadas através do uso de métodos estatísticos diversos e que possibilitarão responder as questões de pesquisa acima delineadas.

Para responder a primeira das questões de pesquisa, seguiu-se a linha das derivadas do Slippery Slope Framework (Müehlbacher, Kirchler, \& Schwarzenberger, 2011).

Apresentam-se, assim, como hipóteses, que uma alta confiança dos contribuintes no Governo tem como resultado mais observância fiscal voluntária; e que uma alta percepção do poder das autoridades fiscais, por parte dos contribuintes, tem como resultado mais observância fiscal forçada.

Pretende-se responder a segunda questão de pesquisa testando a hipótese de que a implementação de políticas públicas baseadas em punições e recompensas gera mais conformidade fiscal.

De forma linear, apresentam-se, portanto, as três hipóteses a serem testadas neste estudo:

$\mathbf{H}_{1}$ : Uma alta confiança dos contribuintes no Governo tem como resultado mais observância fiscal voluntária; 
$\mathbf{H}_{\mathbf{2}}$ : Uma alta percepção do poder das autoridades fiscais, por parte dos contribuintes, tem como resultado mais observância fiscal forçada; e

$\mathbf{H}_{3}$ : A implementação de políticas públicas baseadas em punições e recompensas gera mais conformidade fiscal.

\subsection{Métodos de pesquisa}

A fim de se testar as hipóteses apresentadas neste estudo, serão empregados dois métodos de pesquisa distintos.

Inicialmente, a primeira parte do estudo procurará entender como a confiança dos contribuintes no Governo e a percepção do poder das autoridades, por parte dos contribuintes, influenciam a observância fiscal, respondendo a primeira questão de pesquisa e testando as hipóteses correspondentes $\left(\mathrm{H}_{1}\right.$ e $\left.\mathrm{H}_{2}\right)$.

Para tanto, foi desenvolvido um software, disponibilizado através da internet, que reproduziu o modelo denominado Slippery Slope Framework, criado pelo pesquisador Erich Kirchler, da Universidade de Viena. Nele, os participantes são distribuídos randomicamente em diferentes cenários simulados e instados a informar o montante de tributo que desejam pagar, bem como a responderem questionário em escala likert. Apesar da comparação entre grupos randômicos com cenários alternativos, uma vez que nenhuma intervenção é realizada no "ambiente" e não se procura avaliar diretamente causa e efeito, essa primeira parte do estudo não será denominada experimento, mas meramente um questionário visando à comparação de cenários alternativos.

Na segunda parte do estudo, que pretende responder a segunda questão de pesquisa e testar a hipótese $\mathrm{H}_{3}$, será empregado método experimental, com diferentes intervenções no 
cenário pesquisado e avaliação das respectivas consequências, comparando-se, ao final, resultados entre os grupos e dentro dos grupos.

Oportunamente, os dois métodos serão mais bem detalhados, possibilitando ao leitor a compreensão mais específica da forma como os dados foram coletados e analisados.

\subsection{Justificativa e contribuições}

Benjamin Franklin, um dos "pais" da independência dos Estados Unidos, certa vez citou em cartas privadas: "Nossa nova Constituição já está estabelecida e tem aparência que promete permanência, mas neste mundo nada pode ser dito ser certo, exceto a morte e os impostos" ${ }^{2}$.

Sua concepção pode ser reconstruída através da inexorável constatação de Aristóteles de que o homem é um animal social e, como tal, busca a união e a vida em sociedade para saciar suas necessidades naturais, o que traz como decorrência a interdependência dos indivíduos (Marton, 2003). Como conseqüência, há o surgimento de demandas coletivas, sendo imprescindível a arrecadação de tributos para fazer frente a esses desafios, de modo que, conforme citado por Alm e Torgler (2011), a tributação está longe de ser evitada ${ }^{3}$.

Nesse contexto, e extraído o tom dramático do pensamento de Benjamin Franklin, podemos parafrasear Melis (1950, citado por ludícibus, Martins, \& Carvalho, 2005), dizendo que a história dos tributos confunde-se com a própria história da civilização ${ }^{4}$ ! Vale dizer que os tributos acompanham a vida dos seres humanos, sendo, portanto, inevitável, ao menos dentro de uma conjuntura social na forma como conhecemos.

\footnotetext{
${ }^{2}$ Tradução livre de "Our new Constitution is now established, and has an appearance that promises permanency; but in this world nothing can be said to be certain, except death and taxes". Disponível em https://archive.org/stream/writingsofbenjam10franuoft/writingsofbenjam10franuoft djvu.txt. Acesso em 8 de abril de 2015.

${ }^{3}$ Deve se entender o vocábulo "evitada" no sentido de que os tributos são indispensáveis à sociedade.

${ }^{4}$ Melis (1950) refere-se, originalmente, à história da contabilidade.
} 
Mas tão longa é a história dos tributos como é a da sonegação (Kirchler, 2007; Siqueira \& Ramos, 2005, 2006). Em outras palavras, a sonegação, ou o desejo de praticá-la, provavelmente surgiu no exato momento em que se impôs aos cidadãos a obrigação do pagamento de tributos. Confirmando essa concepção, Alm e Torgler (2011) asseveram que os indivíduos não gostam de pagar tributos e, por isso, buscam maneiras de reduzir o montante a ser recolhido. Em linhas semelhantes, Srinivasan (1973) aduz que a sonegação é uma prática muito difundida, ou, como quer Kirchler (2007), um fenômeno universal, presente em todas sociedades, todos os estratos sociais, todas as profissões, todas as indústrias, todas as religiões e, virtualmente, em todos os sistemas econômicos.

Aquilo que, portanto, pode parecer um problema atual, na verdade é tão antigo quanto a própria civilização, sendo que desde a antiguidade os contribuintes se opõem, não só à obrigação de pagamento, mas, igualmente, à prática inquisitorial das autoridades em busca de informações privadas, necessárias para a correta avaliação do montante a ser tributado (Grossfeld, \& Bryce, 1983).

Prova disso é que a menção sobre o dilema entre pagar e não pagar impostos encontrase mesmo na Bíblia (Marton, 2003). Com efeito, em uma das passagens bíblicas mais conhecidas, Jesus, ao ser confrontado sobre a licitude de se pagar impostos ao Imperador Romano, diz: "Dai, pois, a César o que é de César, e a Deus o que é de Deus" 5 .

Consequentemente, e sendo a sonegação uma prática antiga e característica da sociedade, compete aos respectivos governantes e autoridades tributárias lançar mão de mecanismos com o objetivo de combater essa transgressão, inclusive na árdua tarefa de convencer os contribuintes a cumprir suas obrigações voluntariamente, em que nem sempre são bem-sucedidos.

\footnotetext{
${ }^{5}$ Evangelho segundo Mateus (22:21).
} 
Não é despiciendo retratar a importância da arrecadação tributária, especialmente em um contexto atual de um estado do bem-estar social. A coleta de tributos é fonte primária para fazer frente aos gastos governamentais e viabilizar os investimentos públicos necessários ao bem-estar da população. Ademais, a política fiscal serve de instrumento para regulação da economia, redução da desigualdade através de melhor distribuição de renda e até mesmo aumento da propensão ao consumo pela população, como era propagado por John Maynard Keynes, conforme aduz Afonso (2012).

Podemos concluir, nessa linha, que a sonegação fiscal tem o potencial de afetar de forma negativa e de maneira significante o desenvolvimento econômico do país (Siqueira \& Ramos, 2006). Para se ter uma ideia do seu impacto na arrecadação tributária brasileira, em 09 de maio de 2015 estimava-se um total arrecadado em tributos no país em torno de um seiscentos e setenta e oito bilhões de reais ${ }^{6}$, ao passo que, de outra ponta, o total sonegado atingia o montante estimado de 183 bilhões de reais ${ }^{7}$, ou seja, quase $27 \%$ do valor da arrecadação total, com o qual seria possível, apenas a título de ilustração, pagar o Bolsa Família ${ }^{8}$ para toda a população brasileira por um período superior a um ano ${ }^{9}$.

Siqueira e Ramos (2006) também fornecem informações significativas que ilustram ainda melhor esse cenário. Segundo os mencionados autores, as estimativas mais realistas situam o nível de sonegação no país entre $15 \%$ e $40 \%$ do total arrecadado, o que confirma o parâmetro acima citado. Continuam dizendo que na Rússia o nível de sonegação atingia 42,7\% em 1997 e no Chile 26\% em 1995. Pertinente destacar ainda o estudo conduzido pelo Sindicato Nacional dos Procuradores da Fazenda Nacional (Sinprofaz) ${ }^{10}$, que estima em $23,6 \%$ o nível de

\footnotetext{
${ }^{6}$ Conforme estimativa da Associação Comercial de São Paulo, disponível em http://www.impostometro.com.br/. Acesso em 9 de maio de 2015.

${ }^{7}$ Conforme estimativa do Sinprofaz - Sindicato Nacional dos Procuradores da Fazenda Nacional, disponível em http://www.quantocustaobrasil.com.br/. Acesso em 9 de maio de 2015.

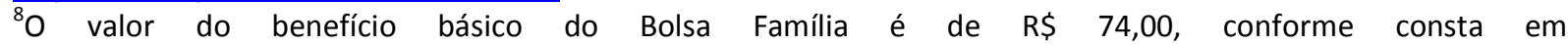
http://www.mds.gov.br/bolsafamilia. Acesso em 9 de maio de 2015.

${ }^{9}$ Considerando uma população de 190.732.694, conforme último Censo, realizado em 2010, disponível em http://www.ibge.gov.br/home/estatistica/populacao/censo2010/default.shtm. Acesso em 9 de maio de 2015.

${ }^{10}$ Disponível em http://www.quantocustaobrasil.com.br/artigos/sonegacao-no-brasil\%E2\%80\%93uma-estimativado-desvio-da-arrecadacao-do-exercicio-de-2014. Acesso em 8 de abril de 2015.
} 
sonegação fiscal no Brasil em 2014. Esses números revelam ser imperativo que as autoridades combatam essa prática, na medida em que o problema compromete os investimentos necessários para o crescimento do país.

Para combater a evasão fiscal, ao seu turno, o Brasil faz uso predominante de mecanismos punitivos, seguindo tendência dominante no que tange a práticas de política pública fiscal (Murphy, 2008). A moderna pesquisa sobre observância fiscal convencionou designar de "paradigma do crime" o emprego dessas ferramentas de coerção, em que o contribuinte é visto como um indivíduo racional, que procura de todas as formas maximizar sua utilidade. Como consequência, parte-se do pressuposto de que a melhor forma de reduzir a sonegação é através do aumento do risco do contribuinte, seja ampliando a probabilidade de ele ser auditado ou através da elevação de multas por sonegação, que no Brasil atingem patamares estratosféricos.

Ocorre que, atualmente, é consenso no meio acadêmico que o comportamento do contribuinte é muito mais complexo do que inicialmente se poderia supor, envolvendo questões que perpassam o desejo racional de aumento do retorno financeiro. De acordo com essa nova visão, são diversos e, muitas vezes desconhecidos, os fatores que influenciam a inobservância fiscal, mas, certamente, a forma como se dá a interação de contribuintes, autoridades e Governo figura entre as que merecem expressiva atenção daqueles que lidam com a problemática.

Assume-se, portanto, que a sonegação fiscal não se refere tão-somente a uma decisão individual e racional do cidadão, ou mesmo um paradigma único, havendo diversos fatores e interações de múltiplos atores que influenciam o comportamento do contribuinte (Kirchler, 2007). Entretanto, é curioso observar que no Brasil essa perspectiva é pouco abordada pela academia, bem como não aparenta compor de forma significativa a agenda de discussão dos governantes. 
Nessa vereda, quando o debate é trazido ao campo doméstico, engana-se quem o simplifique, afirmando que a evasão fiscal no país é fruto da inexistência de contraprestação por parte do Estado em bens e serviços públicos de qualidade. Embora a afirmação não seja completamente equivocada, as razões que influenciam a sonegação são muito mais abrangentes e complexas. Se o motivo indicado fosse de todo verdadeiro, então os países desenvolvidos, que se destacam pela qualidade dos serviços públicos ofertados aos cidadãos, não apresentariam expressivas taxas de evasão fiscal. Entretanto, não é despropositado dizer que, a despeito das particularidades locais, a evasão fiscal é uma prática extensa e comum em quase todos os países (Alm \& Torgler, 2011).

Para ilustrar a afirmação de que o comportamento do contribuinte é pouco debatido no país, vale citar os programas de anistia fiscal (Refis, Refis da Crise, Paes) que favorecem contribuintes que deixaram de cumprir suas obrigações, ao oferecer desconto no valor da dívida e, muitas vezes, amplo e facilitado prazo de pagamento. Não se pretende, neste momento, fazer qualquer juízo de valor sobre tais parcelamentos, que merecem atenção mais detida; mas não se pode deixar de avaliar que se trata de prática tributária com elevado potencial de afetar decisões futuras dos contribuintes, inclusive no sentido de incliná-los ao inadimplemento de suas obrigações, na esperança de serem beneficiados com eventual anistia.

A par disso, aparentemente o Governo visualiza esses programas como mera oportunidade de aumentar a arrecadação tributária de forma imediatista, deixando de lado qualquer análise comportamental e suas consequências em médio e longo prazo.

Portanto, o presente estudo pretende avaliar a prática de sonegação fiscal considerando outros paradigmas, e não apenas o tradicional, que considera o contribuinte um ser racional. Propõe-se um estudo que, sem desconsiderar esse paradigma, também abranja o que se convencionou chamar de "paradigma do serviço", em que o clima envolvendo a interação de contribuintes, autoridades fiscais e Governo constitui vetor que afeta, de forma considerável, os níveis de observância tributária (Kirchler, 2007). Adicionalmente, objetiva-se avaliar se o 
comportamento do contribuinte pode ser influenciado através da utilização de consequências que proporcionem seu aprendizado no sentido de aumentar a conformidade fiscal, nos termos ensinados pela Análise do Comportamento Humano, o que se fará através de simulação experimental, contrapondo políticas públicas baseadas em sanções e recompensas, efetivas ou potenciais.

Torna-se evidente, destarte, que o tema central do presente estudo envolve assunto de interesse social e de grande relevância acadêmica, eis que toda a sociedade é afetada pelas políticas públicas tributárias, direta ou indiretamente, o que por si só justificaria o mérito da pesquisa.

Pretende-se, igualmente, contribuir para o desenvolvimento acadêmico, ao colaborar para o amadurecimento do conhecimento científico sobre a observância fiscal, tratando-se de pesquisa inédita no país, seja pela abrangente abordagem empregada, seja pelo método científico escolhido ou mesmo pelo vasto banco de dados coletados, que possibilita fornecer amplas evidências empíricas sobre o tema. É de ressaltar, por oportuno, que pouco se sabe acerca das tendências sobre observância tributária na América Latina, eis que os estudos concentram-se especialmente nos Estados Unidos, conforme destacou Torgler (2003a).

Ademais, o estudo tem potencial de contribuir para o debate acerca das políticas públicas fiscais empregadas pelo Governo, buscando uma melhora nos níveis de conformidade tributária, seja através da adoção de políticas fiscais alternativas cuja abordagem fuja do tradicional paradigma econômico clássico, bem como do emprego de conceitos da Análise do Comportamento Humano no sentido de influenciar as atitudes dos contribuintes em prol da observância legal.

Embora a proposta pareça demasiadamente ousada, Alm e Torgler (2011) citam que há evidências demonstrando que a cada ano mais os resultados de experimentos na área fiscal têm atraído a atenção da administração pública, de modo que este estudo pode significar um 
avanço nesse sentido. Referendando essa ideia, Baer, Wolf e Risley (1968) afirmam ser permitido presumir que a aplicação dos ensinamentos behavioristas, quando efetiva, pode proporcionar a aprovação social e a adoção que assegure mais bem-estar social. Se no Brasil ainda não atingimos esse patamar, somente a ousadia pode servir de vetor para a mudança desse quadro preocupante.

Afinal, se os tributos são certos como a morte, como dramatizou Benjamin Franklin, é indispensável a busca pelo entendimento mais amplo acerca dos fatores que abrangem o comportamento do contribuinte. Tudo isso justifica a importância deste estudo, tratando-se de tema inquietante e essencial para a academia e para toda a sociedade.

\subsection{Estrutura do trabalho}

Neste capítulo inicial, buscou-se introduzir o tema ao leitor, possibilitando-lhe compreender o contexto em que se insere esta pesquisa, seus objetivos, justificativas, questões de pesquisa, hipóteses e método a ser empregado, situando o estudo de forma macro.

O segundo capítulo apresenta os fundamentos teóricos do estudo, destacando a análise do paradigma econômico clássico, em contraposição à abordagem mais recente, que vem captando a atenção dos pesquisadores, qual seja, o "paradigma do serviço". Na sequência, analisam-se os principais conceitos da Análise do Comportamento, na forma proposta por Skinner, incluindo-se uma avaliação integrativa dos assuntos abordados no capítulo.

No terceiro capítulo, os procedimentos metodológicos, brevemente citados neste introito, são detalhados, possibilitando ao leitor uma ampla visão sobre a coleta de dados e os instrumentos aplicados.

No quarto capítulo, as hipóteses são testadas e os resultados são apresentados e analisados, respondendo-se as questões de pesquisas correspondentes. 
O quinto e derradeiro capítulo apresenta as considerações finais, incluindo aspectos relacionados a limitações de pesquisa e sugestões para futuros estudos. 


\section{REFERENCIAL TEÓRICO}

As bases teóricas do presente estudo são, essencialmente, a literatura científica sobre observância fiscal e os ensinamentos da Análise do Comportamento, especialmente na forma desenvolvida por Skinner.

Na primeira parte, a literatura sobre observância fiscal é visitada de maneira ampla, demonstrando-se a evolução acadêmica na pesquisa do tema, com abordagem dos paradigmas "do crime" e "do serviço", incluindo os recentes estudos que demonstram o Estado da Arte dessas pesquisas.

Na sequência, é abordada parte dos ensinamentos da Análise do Comportamento, discutindo-se de que forma ela pode ser empregada na busca de mais conformidade fiscal, propondo-se uma integração com os conceitos tratados na primeira etapa da análise teórica.

\subsection{Observância tributária}

\subsubsection{Paradigma do crime}

Uma das explicações basilares para a observância fiscal centra-se numa suposta racionalidade econômica dos indivíduos, em que a ameaça de detecção e punição é o principal fator de influência nas decisões sobre o pagamento ou sonegação de tributos. Segundo essa visão, o contribuinte se comporta como se estivesse participando de um jogo, no qual a aposta envolve a avaliação da utilidade esperada em razão dos benefícios advindos de eventual evasão fiscal exitosa e as incertezas de detenção e punição, de modo que o pagamento de tributos dáse em razão do receio de ser auditado e punido (Alm \& Torgler, 2011; Alm et al., 1992b; Leviner, 2008). 
Allingham e Sandmo (1972) são considerados os precursores desse paradigma, tendo publicado o seminal estudo "Income Tax Evasion: A Theoretical Analysis", baseado na famosa obra de Becker (1968) sobre crime e punição. Naquele artigo, os autores veem o contribuinte enredado em um dilema envolvendo o benefício econômico da prática de evasão fiscal e o risco de ser descoberto e, consequentemente, punido. Segundo os autores, a decisão do indivíduo envolve duas alternativas: declarar o montante real de sua renda ou optar pela declaração irreal, dependendo da probabilidade de ser investigado. Sendo essa probabilidade reduzida, o contribuinte irá optar por maximizar sua utilidade econômica, declarando apenas parte ou nenhuma renda.

O paradigma econômico clássico pressupõe, portanto, que a determinação de pagar tributos é uma decisão sob incerteza (Müehlbacher et al., 2011). Segundo Allingham e Sandmo (1972), a dúvida funda-se na constatação de que a omissão ou equívoco na declaração da renda não provoca a reação automática das autoridades fiscais e a imposição de penalidades. Dessa forma, conforme relata Kirchler (2007), o contribuinte se comporta como em um jogo, no qual as incertezas o fazem deparar-se com os seguintes dilemas: a) obedecer à lei e ter a certeza do montante de riqueza sacrificado; b) desobedecer à lei, obtendo, em caso de êxito, um ganho; ou c) desobedecer à lei e amargar uma perda acentuada em razão da deteç̧ão e punição.

Desse modo, Murphy (2008) resume o paradigma econômico aduzindo que os indivíduos avaliam as oportunidades e riscos, desobedecendo à lei quando concluem que a probabilidade de serem detectados e punidos é pequena em comparação com o lucro obtido em razão do ato. Trata-se de decisão eminentemente racional e utilitarista.

Essencial ressaltar, contudo, que considerar a real probabilidade de ser fiscalizado como fator de decisão pode não ser adequado, na medida em que a percepção de risco tende a ser mais relevante para o comportamento do contribuinte (Bobek \& Hatfield, 2003). Isso porque essa percepção varia entre os indivíduos, de modo que determinado contribuinte pode superavaliar a probabilidade de ser detectado e punido, o que forneceria uma explicação 
adicional para a observância tributária (Alm et al., 1992b; Feld \& Frey, 2007; Gemmell \& Ratto, 2012). De acordo com Alm e Torgler (2011) e Alm et al. (1992b), os resultados empíricos proporcionam fortes evidências de que parte dos indivíduos superdimensiona a real possibilidade de ser punida, como demonstraram Erard e Feinstein (1994), o que resulta em elevada observância fiscal, quando esse risco é, na verdade, reduzido, infirmando o paradigma racional.

Consequentemente, seria mais apropriado avaliar a percepção de risco do contribuinte do que a real probabilidade de detecção e punição, na medida em que a decisão individual se baseia em percepções próprias, muitas vezes destoantes da realidade.

De todo modo, assumindo os pressupostos do paradigma econômico clássico de racionalidade do contribuinte, como bem averbado por Allingham e Sandmo (1972), o Governo então disporia, como ferramentas para o combate da sonegação fiscal, da alíquota do tributo, do peso da punição e dos gastos com a realização de auditorias. A alíquota do tributo afeta os níveis de observância, ao interferir na utilidade econômica da decisão do contribuinte. O peso da punição, por sua vez, aumenta o risco dos contribuintes, tais quais os investimentos com auditorias, que aumentam a probabilidade de auditagem.

Considerando que, segundo Alm, Kirchler e Müehlbacher (2012a), a alíquota do tributo gera efeitos ambíguos na observância tributária, restariam, então, apenas duas ferramentas efetivas para se reprimir a adoção de condutas ilegais por parte dos contribuintes: frequentes auditorias e sanções rígidas (Alm \& Torgler, 2011; Leviner, 2008). Segundo Leviner (2008), essas duas ferramentas de coerção são substitutas uma da outra, embora nada impeça que sejam utilizadas conjuntamente. Aduz o autor, que embora seja esperada uma redução na arrecadação tributária quando diminuida a probabilidade de o contribuinte ser fiscalizado, essa perda pode ser compensada através do aumento da severidade da punição por sonegação, podendo o Governo escolher qual das duas práticas Ihe é mais conveniente. Conclui, contudo, asseverando que o "mundo real" é muito mais complexo do que sugere esta análise. 
Devido a essa ênfase no aumento da probabilidade de o contribuinte ser auditado e, caso tenha transgredido a lei, punido, que do paradigma econômico clássico deriva o "paradigma do crime", cujo nome advém, justamente, da visão das autoridades de que o contribuinte é um potencial criminoso que precisa ser dissuadido de desobedecer a lei (Alm \& Torgler, 2011), bem como da tentativa incessante, por parte dessas autoridades, de encontrálos e puni-los, o que cria um ambiente de "polícia e ladrão", conforme dá conta Kirchler (2007).

Válido ressaltar que esse modelo já foi objeto de avaliação no Brasil, onde se destaca o estudo conduzido por Siqueira e Ramos (2006), que propuseram um modelo extensivo ao proposto por Allingham e Sandmo (1972). Esse modelo sugere que um aumento na probabilidade de detecção da infração e na imposição de penalidades reduz a evasão fiscal; que um aumento na alíquota marginal do imposto também reduz a evasão, embora os autores alertem que há pesquisas indicando o contrário, como dito acima; que um aumento na eficiência de detecção da malha reduz a sonegação, de modo que investimentos na eficiência das auditorias realizadas pela Secretária da Receita Federal podem gerar resultados significativos.

Em conclusão, os modelos que repousam numa suposta racionalidade dos indivíduos têm como mote o controle do contribuinte por meio de métodos de coerção, baseado proeminentemente na deteç̧ão e punição dos transgressores da lei. Quando o emprego desses métodos é efetivo, a observância do contribuinte é derivada do exercício do poder coercitivo das autoridades, o que se convencionou chamar de "observância forçada" (Kirchler, 2007).

\subsubsection{Observância forçada}

Conforme visto no tópico precedente, o "paradigma do crime" pressupõe a racionalidade do contribuinte. Como consequência, no momento de decidir pelo cumprimento de suas obrigações fiscais, o indivíduo contrabalanceia riscos e benefícios. Tem-se em tese, 
pois, que, caso o Poder Público tenha êxito em aumentar o risco, o contribuinte tenderá a pagar integralmente seus tributos. Decorrência lógica desse raciocínio é que o Governo pode encorajar a observância fiscal, aumentando fiscalizações ou a severidade das punições, podendo ainda utilizar ambas as ferramentas de modo concomitante, o que Alm e Torgler (2011) chamam de insight plausível. O comportamento do contribuinte, nesse caso, dá-se em razão da coerção exercida pelo Poder Público, ou seja, é um ato forçado, e não voluntário.

Temos, assim, que a observância forçada está atrelada diretamente ao poder de coerção exercido pelas autoridades fiscais. Russell (1961) define poder como o potencial de influenciar um terceiro a fazer algo que, em princípio, ele não faria. Alm et al. (2012b), ao seu turno, assinalam que há diversos tipos de poder, como é o caso do poder coercitivo, por exemplo, em razão de lei prevendo punição, e do poder de influência em razão de recompensas.

Quando se trata do poder exercido na abordagem do "paradigma do crime", está-se diante, exatamente, do poder coercitivo, ou seja, a influência exercida pelo Estado se dá com o estabelecimento de leis determinando comportamentos e o uso da força para punir aqueles que as transgredirem. A observância desse tipo de poder é chamada de observância forçada, haja vista que não se dá voluntariamente, mas sim em resposta a pressão exercida pelas autoridades (Kirchler, 2007). Esse contexto coercitivo tem como consequência a criação de um ambiente onde prevalece o conflito entre autoridades e contribuintes (Kirchler, 2007). Os primeiros procuram a todo custo aumentar a percepção dos contribuintes acerca dos riscos envolvidos na prática de sonegação fiscal. Esse controle aversivo do comportamento acarreta práticas de contracontrole por parte dos contribuintes, sempre buscando a manutenção de uma distância segura das autoridades. A cooperação é relegada a segundo plano, ao contrário do que ocorre no "paradigma do serviço", sendo a observância decorrente do poder de coerção das autoridades, e não de ato voluntário do contribuinte. 


\subsubsection{Paradigma do serviço}

Atualmente é bem assentada a opinião de que o paradigma econômico clássico é limitado (Alm, 1991; Alm et al., 1992b; Alm et al., 2012a, 2012b; Bobek \& Hatfield, 2003; Bosco \& Mittone, 1997; Dalmácio, Berger, Dallapicula \& Alencar, 2009; Feld \& Frey, 2007; Kirchler et al., 2014; Lisi, 2012a; Posner, 2000; Siqueira \& Ramos, 2005, 2006). Essa limitação decorre do reconhecimento de que os seres humanos não agem unicamente visando seus próprios interesses e a maximização da utilidade de suas decisões, havendo diversos exemplos cotidianos demonstrando que consciência e sentimentos morais também desempenham um papel importante nas escolhas dos indivíduos (Frank, 1987).

Weigel, Hessing e Elffers (1987) criticam os modelos tradicionais de evasão fiscal que assumem que todos os contribuintes irão declarar valores de renda inferiores e serão dissuadidos apenas quando a probabilidade de deteç̧ão e a severidade das punições forem altas. Isso porque, segundo os autores, certas situações e ambientes instigam o contribuinte à prática de atos evasivos e certos tipos de personalidade são particularmente inclinados a esse comportamento. Concluem afirmando que seria insensato desconsiderar outras motivações na pesquisa sobre observância fiscal.

Alm e Torgler (2011) bordam oportunas considerações sobre o tema, afirmando que nem sempre o indivíduo se comporta de maneira egoísta, racional e preocupado apenas com seus próprios interesses, como retratado pelo paradigma racional. Segundo os autores, muitos outros fatores afetam o comportamento do contribuinte, em especial aqueles que se fundamentam na ética, sendo impossível compreender de modo integral a observância fiscal sem considerar dimensões dessa natureza. Concluem dizendo que as evidências empíricas comprovam que o paradigma racional é limitado, haja vista que a probabilidade de ser fiscalizado é mínima e, contrariamente ao que se poderia supor, a maioria dos indivíduos cumpre suas obrigações fiscais, opinião reproduzida por Alm et al. (2012b) e Posner (2000). 
Alm et al. (2012b), também nessa linha de pensamento, afirmam que os resultados de pesquisas empíricas sugerem a relevância de outras motivações que perpassam a noção de racionalidade do contribuinte, como é o caso de sentimento de culpa, moralidade e altruísmo. Segundo os autores, as pesquisas demonstram que as motivações são afetadas por normas sociais, justiça, equidade, confiança, reciprocidade, moral tributária e, até mesmo, patriotismo. Concluem averbando que o paradigma racional negligencia muitos elementos essenciais envolvidos no ato de obedecer à lei tributária, na medida em que se funda em uma única motivação utilitarista, desconsiderando outros fatores e atores que interagem com os contribuintes e, igualmente, influenciam seus comportamentos.

Segundo essa compreensão, portanto, são inúmeros os fatores que influenciam o comportamento do contribuinte que não apenas o desejo de obter vantagem financeira imediata e explicam por que muitas pessoas obedecem à lei (Alm \& Torgler, 2006). Injustiça (Alm \& Torgler, 2011; Alm et al., 2012a; Skinner \& Slemrod, 1985; Weigel et al., 1987), oportunidade de sonegar (Alm et al., 2012a; Kirchler, 2007; Weigel et al., 1987), aceitação da prática de sonegação pela sociedade (Alm \& Torgler, 2011; Alm et al., 2012; Skinner, 1974/2006; Weigel et al., 1987), moralidade tributária (Alm \& Torgler, 2006; Frey \& Torgler, 2007; Halla, 2012; Kirchler, 1997), , falta de transparência na aplicação dos recursos públicos (Marton, 2003), segregação mental do tributo devido (Müehlbacher \& Kirchler, 2013), ética (Reckers, Sanders, \& Roark, 1994), desigualdade fiscal (Spicer \& Becker, 1980) são apenas alguns exemplos das motivações que levam o contribuinte a cumprir ou descumprir suas obrigações fiscais, e que só comprovam o quão limitado é o "paradigma do crime".

Até mesmo a idade do contribuinte pode influenciar a observância tributária, já que, segundo revelam as pesquisas empíricas, quanto mais velho for o indivíduo, menor será a sua inclinação para a prática de atos evasivos, como demonstraram Kirchler (1997b, 1999), Müehlbacher e Kirchler (2013), Müehlbacher et al. (2011), Orviska e Hudson (2002) e Slemrod (1985). 
É despropositado, porém, criticar os precursores do paradigma racional por conta de suas limitações. Becker (1968), que inspirou os estudos iniciais sobre observância tributária, ressalva que considerar que um indivíduo cometerá um crime se os benefícios do ato forem superiores aos seus custos é um pressuposto assumido, sobre o qual, inclusive, afirma não haver pretendido discorrer. Isso ocorre devido à dificuldade de introduzir a honestidade dos indivíduos como variável em modelos econômicos (Skinner \& Slemrod, 1985), pressupondo-se sua racionalidade para fins de validade do modelo.

Os próprios autores de um dos seminais artigos sobre o tema (Allingham \& Sandmo, 1972) observam que a evasão fiscal pode tomar muitas formas, sendo improvável uma análise completa do problema. Aduziram que esse paradigma é uma "teoria muito simples", sujeita as críticas, por dar pouca atenção a fatores não pecuniários. Vale dizer que eles não negam que a observância fiscal é tema bem mais complexo que uma análise apressada do paradigma por eles estudado poderia supor, mas, sim, assumem o pressuposto de que, naquele momento, permitia uma análise mais objetiva do assunto.

Mesmo escólio é o de Srinivasan (1973), para quem há contribuintes que declaram sua renda real meramente por princípios, ao passo que outros somente seguem esse caminho se o retorno esperado é aquele considerado ótimo do ponto de vista individual; ou seja, agem racionalmente. Reconhece, consequentemente, que o paradigma racional é limitado, declarando, inclusive, que o comportamento do contribuinte não necessariamente é tão simples quanto o assumido pelo estudo.

Resumindo toda essa análise, Alm et al. (1992b) afirmam que embora evidente que o risco de deteç̧ão e punição afeta a observância fiscal, é igualmente claro que esse não é o único fator de influência do comportamento do contribuinte. A conclusão dos autores baseia-se na constatação de que o paradigma clássico implica reconhecer que, sendo racional, o contribuinte não cumpriria suas obrigações tributárias, devido à pequena probabilidade de serem fiscalizados e punidos. No entanto, alertam que o nível de observância fiscal é 
relativamente alto quando comparado com o que seria esperado em razão do paradigma econômico clássico, o que implica reconhecer sua limitação. Conclusão semelhante é a de Alm e Torgler (2011), para quem há outras razões que impulsionam o contribuinte para o pagamento dos tributos.

Alm et al. (1992b) citam, ainda, que os resultados de pesquisas experimentais sugerem que os indivíduos cumprem suas obrigações tributárias porque reconhecem que isso é imprescindível para garantir a oferta de serviços públicos. Segundo os autores, portanto, um aumento na contraprestação recebida pelos contribuintes aumenta o nível de observância fiscal, fazendo com que a evasão seja reduzida, ainda que a probabilidade de punição também o seja. Isso se deve à tendência do contribuinte de procurar contrabalancear uma suposta diferença entre sua contribuição em favor da comunidade e aquilo que recebe em contrapartida de serviços públicos do Estado (Kirchler, 1997).

Alm et al. (1992b), inclusive, demonstram empiricamente, através de experimento, que há uma correlação positiva entre a observância fiscal de cada indivíduo em determinado período e o montante de serviços públicos recebidos em etapas prévias. Relatam que parte dos indivíduos cumprem suas obrigações tributárias porque valorizam os serviços públicos por eles financiados, o que demonstra que, além da probabilidade de detecção e punição, há outros fatores que afetam a ação do cidadão. Por fim, os resultados revelam que mesmo em condições experimentais, em que o risco de auditoria é elevado, os participantes optaram por descumprir suas obrigações, o que mais uma vez demonstra a limitação do paradigma econômico clássico.

Outra questão que ganha relevância nesse paradigma é a constatação de que há outros atores que interagem no processo de pagamento de tributos (Alm et al., 2012a). Segundo Alm et al. (2012b), os tributos não são pagos através de ato individual, havendo interação do contribuinte, por exemplo, com contadores e agentes fiscais, além de a arrecadação ser gasta por agentes públicos que representam os cidadãos. Nesse sentido, o "paradigma do serviço" também considera que o pagamento de tributos é um ato complexo, que envolve uma série de 
interações, sendo necessário considerar na análise da observância fiscal não apenas um contribuinte racional e egoísta, mas, sim, um cidadão que interage com outros atores, especialmente agentes fiscais e políticos, que influenciam seu comportamento de maneira decisiva (Kirchler, 2007).

Alm et al. (2012a, 2012b) chamam a atenção para o papel decisivo do Governo nesse processo, na medida em que é responsável pelas características do sistema tributário imposto ao contribuinte. Adicionalmente, alertam os autores que o modo como se dá a comunicação, por parte dos agentes políticos, das decisões sobre tributos, e como a arrecadação é alocada são fatores relevantes. Por fim, afirmam que as autoridades fiscais, que agem por mandato do Governo, constituem outra categoria de atores cujos atos são fontes de influência do comportamento dos contribuintes, já que ofertam serviços, implementam controles e impõem sanções.

Feld e Frey (2007) lembram, ainda, que o dispêndio escorreito dos valores arrecadados com tributos tem grande importância, na medida em que o desperdício de dinheiro público corrói a confiança e, consequentemente, afeta a observância fiscal, tanto que McGee, Ho e Li (2008) demonstraram, por meio de estudo empírico, ser a corrupção o mais forte argumento que justifica a prática de evasão fiscal.

Nessa vereda, Alm e Torgler (2011) afirmam que segundo sugerem alguns estudos científicos, parte dos cidadãos não obedece à legislação fiscal se não concordar com a maneira como o Governo gasta os valores arrecadados, avaliando que a alocação dos recursos gerados pelos tributos é injusta e irresponsável. Citam, como exemplo, estudo conduzido pelos próprios autores em outra oportunidade (Alm e Torgler, 2006). Bahl e Bird (2008) e Bird, MartinezVazquez e Torgler (2008) também alertam que a corrupção desempenha papel significativo nessa discussão, sendo necessário um esforço por parte dos governos, para se tornarem mais legítimos e responsivos, favorecendo a observância tributária. 
Pesquisa realizada por Dalmácio et al. (2009) segue a mesma linha, ao demonstrar que uma má gestão do sistema tributário e o sentimento de injustiça em relação ao Governo são os fatores que mais influenciam a tendência do contribuinte de considerar aceitável a sonegação fiscal. É como se o contribuinte encontrasse na má gestão do dinheiro público uma justificativa para a prática evasiva. Skinner e Slemrod (1985) alertam que a evasão fiscal é mais presente entre os contribuintes cuja percepção é de injustiça em razão dos altos impostos pagos. Em linha semelhante, Frey e Torgler (2007) oferecem evidências de que os contribuintes são mais propensos a contribuir quando estão satisfeitos com o Governo e a condução das políticas públicas.

Isso ocorre porque no "paradigma do serviço" pressupõe-se que a confiança do contribuinte no Governo exerce grande influência no nível de observância fiscal, conforme defende, por exemplo, Kirchler (2007), bem como demonstram empiricamente Hammar, Jagers e Nordblom (2009). Torgler (2003b) também verificaram empiricamente que o nível de confiança tem um efeito positivo significativo na moralidade tributária dos cidadãos, com a consequente elevação do nível de observância.

Desse modo, esse paradigma surge da constatação da limitação do paradigma econômico, e centra-se, primordialmente, no reconhecimento de que o contribuinte se assemelha a um cliente que paga seus tributos e, como contrapartida, exige tratamento adequado e o recebimento de serviços públicos de qualidade (Alm \& Torgler, 2011; Kirchler, 2007), daí derivando a alcunha "paradigma do serviço" ${ }^{11}$.

\footnotetext{
${ }^{11}$ Importante destacar que Alm e Torgler (2011) propõem a existência, na verdade, de três paradigmas: paradigma do crime; paradigma do serviço e paradigma da confiança. Esta tríplice divisão, contudo, não se mostra totalmente clara, na medida em que a maioria dos pesquisadores que tratam do tema afirmam que o paradigma do serviço consiste em tratar o contribuinte como uma espécie de cliente, o que fortaleceria a confiança e a cooperação. Kirchler (1999), inclusive, utiliza as expressões, em tradução livre, “abordagem de polícia e ladrão" e "abordagem do cliente e serviço", sendo a primeira baseada no poder das autoridades e a segunda na confiança no Governo. Diante desta ênfase na confiança pode haver certa confusão na divisão tríplice proposta por Alm e Torgler (2011), optando-se, assim, apenas pela dicotomia "paradigma do crime" e "paradigma do serviço".
} 
Feld e Frey $(2002,2007)$ sustentam a existência de uma verdadeira relação contratual entre contribuinte e o Estado, um lado com a obrigação de entregar parte de seus recursos e o outro com o dever de oferecer serviços públicos como contraprestação. Os autores complementam afirmando que o modo como o contribuinte é tratado afeta sua postura, fazendo analogia com o cliente que se dispõe a pagar um preço maior por um produto em razão do tratamento superior que é oferecido por determinado estabelecimento comercial. Hartner, Rechberger, Kirchler e Schabmann (2008) e Kirchler (2007) chamam isso de justiça procedimental, ou seja, tratamento adequado empregado pelas autoridades, incluindo respeito, dignidade e educação.

Deixa o cidadão, assim, de ser tratado como um criminoso racional que apenas busca o melhor caminho para desobedecer às leis e maximizar sua utilidade, que fundamenta o "paradigma do crime", passando a ser visto como um verdadeiro cliente da administração pública, estabelecendo-se uma relação de respeito, que gera confiança e um clima de cooperação entre esses atores sociais (Kirchler, 2007).

Em tempo ressaltar que, conforme alerta Kirchler (2007), esse clima cooperativo não depende unicamente da qualidade dos serviços recebidos. Segundo o autor, é imperativa a existência de leis simples e claras, plenamente compreensíveis pelos contribuintes; que haja orientação adequada sobre as regras fiscais; uma distribuição equânime da carga tributária, possibilitando a percepção de que o sistema pratica justiça redistributiva; garantia de procedimentos administrativos apropriados e eficiente comunicação de normas sociais; promovendo a colaboração concomitantemente com o aprimoramento da moralidade tributária. Todos esses fatores, unidos, incluindo o fornecimento de serviços públicos de qualidade, favorecem a observância fiscal, aumentando a arrecadação tributária.

Halla (2012) também reconhece a importância de normas sociais que envolvam considerações morais acerca da obrigação tributária. Não se trata aqui do pagamento de tributos em cumprimento a normas legais, mas, sim, da observância às normas implícitas que 
vigoram na sociedade em relação à obrigação moral de cada um contribuir com sua quotaparte para o bem coletivo. $\mathrm{O}$ autor traz evidências de que a moralidade tributária afeta o comportamento do contribuinte, sendo demonstrado que nem sempre o cumprimento das obrigações se dá em razão de lei e sua expectativa de punição. Alm (1991), ao seu turno, também enfatiza a importância das normais sociais, esclarecendo que as evidências demonstram que aqueles que creem que os demais membros da sociedade sonegam são mais inclinados a agir da mesma forma, o que é confirmado pelo estudo experimental conduzido por Alm, McClelland e Schulze (1999)

Em suma, o "paradigma do serviço" contrapõe-se ao "paradigma do crime". O papel das autoridades e dos contribuintes é totalmente antagônico: no primeiro, as autoridades agem no sentido de orientar, fortalecer a cooperação e a confiança, obtendo a observância voluntária dos contribuintes, que são tratados como uma espécie de cliente, que colaboram através do recolhimento de tributos e recebem, em contrapartida, tratamento adequado e serviços de qualidade; no segundo, ao seu turno, as autoridades agem como policiais, sempre alertas para detectar transgressores da lei tributária e aplicar as severas sanções daí decorrentes, na medida em que se pressupõe que contribuinte age racionalmente tentando aumentar seu benefício econômico individual, safando-se do rigor da lei. O "paradigma do serviço", portanto, fortalece a observância voluntária, ao contrário do "paradigma do crime", que visa à observância forçada.

\subsubsection{Observância voluntária}

Como visto acima, o fato de tratar o contribuinte como um "cliente" da administração pública, considerando que ele contribui para a arrecadação orçamentária e, como contrapartida, merece receber serviços de qualidade e ser tratado com respeito e dignidade, afeta positivamente o nível de observância tributária. Ao agir dessa forma, as autoridades criam um clima de cooperação entre os atores sociais, emergindo, como consequência, uma 
observância fiscal voluntária, e não forçada em razão da coerção exercida pelo Estado (Kirchler, 2007).

Tal efeito decorre do fato de que os contribuintes que acreditam na administração tributária, especialmente em razão do esforço das autoridades para serem justas e respeitosas, são mais propensos a obedecer à legislação fiscal do que aqueles que têm percepções negativas nesse sentido, especialmente considerando que as pessoas tendem a adotar o mesmo tratamento que recebem de terceiros, em razão da regra de reciprocidade (Leviner, 2008).

Ao contrário do que se poderia supor, segundo Alm et al. (2012b), os contribuintes reconhecem que os valores dos tributos são utilizados para o bem comum e compreendem a necessidade de financiamento da atividade pública. De se esperar, portanto, que a observância fiscal seria uma atitude natural. Contudo, conforme alertam os autores, eles podem discordar ou duvidar da eficiência da alocação desses recursos por parte dos agentes políticos, bem como suspeitar que outros indivíduos deixam de arcar com sua quota-parte, criando uma sensação de injustiça. Em razão dessa constatação, concluem que a forma como se dá a interação dos atores sociais, especialmente contribuintes, Governo e autoridades, pode ajudar a criar um clima cooperativo, que dependerá, primordialmente, da existência de um elevado nível de confiança no Governo e nas autoridades.

Essa interação dos atores envolvidos no processo de observância tributária é vista por Alm et al. (2012b) como uma espécie de contrato psicológico envolvendo contribuintes, Governo e autoridades fiscais. Isso implica que os contribuintes confiarão seus recursos ao Governo na esperança de que sejam eles investidos de forma eficiente. Os autores alertam, contudo, que caso essa confiança seja quebrada, causando desapontamento aos contribuintes, esse contrato psicológico é violado, de modo que eles tenderão a deixar de cooperar voluntariamente. 
Kirchler (2007) é, igualmente, do mesmo parecer, afirmando que a observância voluntária depende primordialmente da confiança dos contribuintes no Estado e nas autoridades públicas, sendo influenciada especialmente pela percepção de justiça e das normas sociais, o que, por sua vez, robustece a cooperação e a observância voluntária. Essa cooperação verifica-se quando os agentes públicos também se mostram dispostos a colaborar com os contribuintes, oferecendo ajuda de forma positiva, sempre buscando um diálogo aberto, a fim de evitar o conflito tributário (Leviner, 2008)

A observância voluntária, logo, está diretamente relacionada com o nível de confiança da sociedade no Governo e nas autoridades públicas. Nas palavras de Kirchler (2007), a abordagem praticada pelas autoridades tem importância crucial para o estabelecimento de uma relação de confiança e observância fiscal voluntária. Ao serem tratados como clientes, os contribuintes dispõem-se a cooperar, especialmente ao perceberem que as leis e os procedimentos fiscais são justos.

O "paradigma do serviço", como se depreende, tem como mote uma interação respeitosa dos atores envolvidos no sistema tributário, procurando fortalecer a confiança no Governo e nas autoridades e privilegiando a cooperação e a observância fiscal voluntária, em detrimento da observância forçada, em contraposição aos pressupostos do "paradigma do crime".

A observância voluntária é considerada superior à observância forçada, na medida em que esta exige altos investimentos por parte das autoridades (Skinner \& Slemrod, 1985), haja vista depender, em grande medida, da probabilidade de o contribuinte ser auditado e punido, o que impõe frequentes e eficientes auditorias fiscais. Ainda que se opte pelo aumento do rigor da sanção, em detrimento do aumento da probabilidade de detecção, alguns efeitos indesejados, como o aumento da sensação de injustiça, deterioram a confiança do contribuinte no sistema tributário, afetando a observância voluntária e, consequentemente, os níveis de arrecadação fiscal. 


\subsubsection{Integrando os paradigmas do crime e do serviço}

Foi abordado anteriormente que o "paradigma do crime" utiliza estratégias visando à observância da lei de forma forçada, ao passo que o "paradigma do serviço" fundamenta-se em caminho oposto, incentivando a observância voluntária.

O "paradigma do crime" pressupõe, portanto, a racionalidade do contribuinte, de modo que a observância da lei não pode ser dada como certa, necessitando de investimentos públicos e particulares para garantir seu cumprimento (Becker, 1968). Dentre as ferramentas à disposição das autoridades para garantir o sucesso dessa empreitada, destacam-se a severidade da punição e o aumento da probabilidade de detecção, sendo que esta última é considerada dispendiosa (Kirchler, 2007; Kirchler et al., 2014), canalizando aqueles investimentos.

Em consequência, surge um sério problema de alocação de recursos. Aumentar a probabilidade de deteç̧ão gera mais receitas, porém exige altos investimentos por parte do Poder Público (Skinner \& Slemrod, 1985; Raskolnikov, 2006). Para evitá-los, é natural que o Governo opte pelo aumento das multas fiscais, compensando a falta de investimento em auditorias (Becker, 1968; Kirchler, Müehlbacher, Kastlunger, \& Wahl, 2010; Raskolnikov, 2006), o que resulta em penas draconianas (Siqueira \& Ramos, 2005), como parece ser o caso do Brasil, onde algumas penalidades atingem $225 \%$ do valor sonegado ${ }^{12}$. Becker (1968) dá conta de que essa abordagem preferencial à severidade da punição, em contraponto com o aumento da probabilidade de detecção, já era adotada pelos países anglo-saxões nos séculos XVII e XIX, sendo que, na época de seu estudo, a mesma prática era mantida por países comunistas e subdesenvolvidos, panorama que parece não ter se alterado.

\footnotetext{
${ }^{12}$ Recentemente o Supremo Tribunal Federal decidiu que as multas por sonegação fiscal não podem superar $100 \%$ do valor sonegado, conforme notícia divulgada no Jornal Valor Econômico de 26/01/2015.
} 
Essa abordagem, embora do ponto de vista econômico possa parecer apropriada, não suporta uma análise mais rigorosa. Beccaria (1764/2012) já aduzia que a probabilidade de deteç̧ão é mais decisiva do que o peso da punição, com o que concordam autores mais recentes, como, por exemplo, Leviner (2008). Efetivamente, de nada adianta a punição ser extremamente drástica, se a probabilidade de detecção for mínima, o que, aliás, é asseverado também por Weigel et al. (1987), ao afirmarem que o medo da punição é função da certeza da detecção e da severidade do castigo, de modo que a inibição da prática delituosa depende da perspectiva de o crime ser descoberto, porquanto, não havendo probabilidade de deteç̧ão, não há possibilidade de punição. Friedland, Maital e Rubenberg (1978), porém, contradizem essa concepção através de pesquisa empírica, já que, em condições experimentais, verificaram resultados concluindo que multas elevadas geram efeito mais significativo na observância fiscal do que a realização de auditorias frequentes. Há que se destacar, porém, que a magnitude da multa não se mostrou estatisticamente significante em análise de regressão e correlação, bem como o fato de a quantidade de participantes do experimento ser reduzida (15), o que deixa dúvida acerca da validade dos achados.

A par dessa divergência, Skinner (1974/2006) oferece-nos excepcional exemplo defendendo a importância da fiscalização para fins de cumprimento de regras por parte dos cidadãos. Segundo o autor, um motorista que não pare em um sinal vermelho não corre apenas o risco de causar um acidente, como também de ser punido pela infração de trânsito. Apenas por indução de consequências, como é o caso da punição, o motorista pode se comportar no sentido de cumprir a regra que determina a parada do veículo. Contudo, o autor relata que havendo um policial visível ao motorista, será ainda mais provável seu comportamento no sentido de obedecer à norma, na medida em que isso o alerta para a probabilidade da punição. De nada adiantaria, todavia, a punição pela transgressão da lei de trânsito ser excessiva, se a probabilidade de ser imposta fosse reduzida. Similarmente, a presença de agentes de fiscalização tem efeito no nível de observância fiscal, pois o receio de ser punido reforça a indução do contribuinte acerca da consequência de ser punido, aumentando a probabilidade de ele se abster de praticar a conduta ilegal. 
Ainda nessa toada, o aumento exagerado da punição acarreta sérios efeitos deletérios. Uma punição excessiva gera mais resistência, litígios fiscais e custos para a administração tributária (Raskolnikov, 2006). Ademais, desgasta a confiança no Governo, levando os contribuintes a adotar atitudes negativas em face das autoridades (Alm et al., 2012a), o que prejudica a observância voluntária, que, como visto anteriormente, é fundamental para o aumento da arrecadação tributária (Kirchler, 2007). Tanto pior em ambientes em que a probabilidade de detecção é reduzida, já que o contribuinte "agraciado" com uma auditoria e a consequente punição sente-se extremamente injustiçado, prejudicando, ainda mais, sua confiança no Governo, especialmente se a sanção for excessiva.

Leviner (2008) é absolutamente enfático sobre o tema, ao afirmar que impor penas extremamente severas para poucos indivíduos é arbitrário, draconiano e muito discriminatório, notadamente porque muitos praticam a sonegação, porém apenas poucos são detectados e punidos. Aduzem os autores que o manejo de punição de forma extrema prejudica o Estado Democrático de Direito, com alto risco de causar um amplo conflito entre cidadãos e Governo. Entendimento semelhante têm Skinner e Slemrod (1985), ao dizer que um sistema em que poucos contribuintes são punidos severamente causa um sentimento generalizado de injustiça, na medida em que fere a equidade que deve prevalecer entre os cidadãos.

Por outro lado, o contribuinte que não cumpre suas obrigações e não é punido muito provavelmente irá repetir esse comportamento no futuro, haja vista que, em seu julgamento, o risco de ser punido é mínimo, tudo em razão de suas experiências passadas (Weigel et al., 1987).

Seguindo essa linha de pensamento, e aceitando um dos pressupostos do "paradigma do serviço", segundo o qual a confiança é vetor de observância fiscal voluntária, tem-se então um círculo perversamente vicioso, em que o Governo, dada a reduzida cooperação dos contribuintes, resolve robustecer a observância forçada, e, devido ao fato de o aumento da 
probabilidade de deteç̧ão originar custos demasiados, opta por impor penas graves àqueles poucos que são flagrados transgredindo a lei. A imposição de penas drásticas para escassos contribuintes, por sua vez, causa um desgaste ainda maior na observância voluntária, obrigando o Governo a impor, ainda mais, a observância forçada. Esse processo circular é ilustrado pela Figura 1.

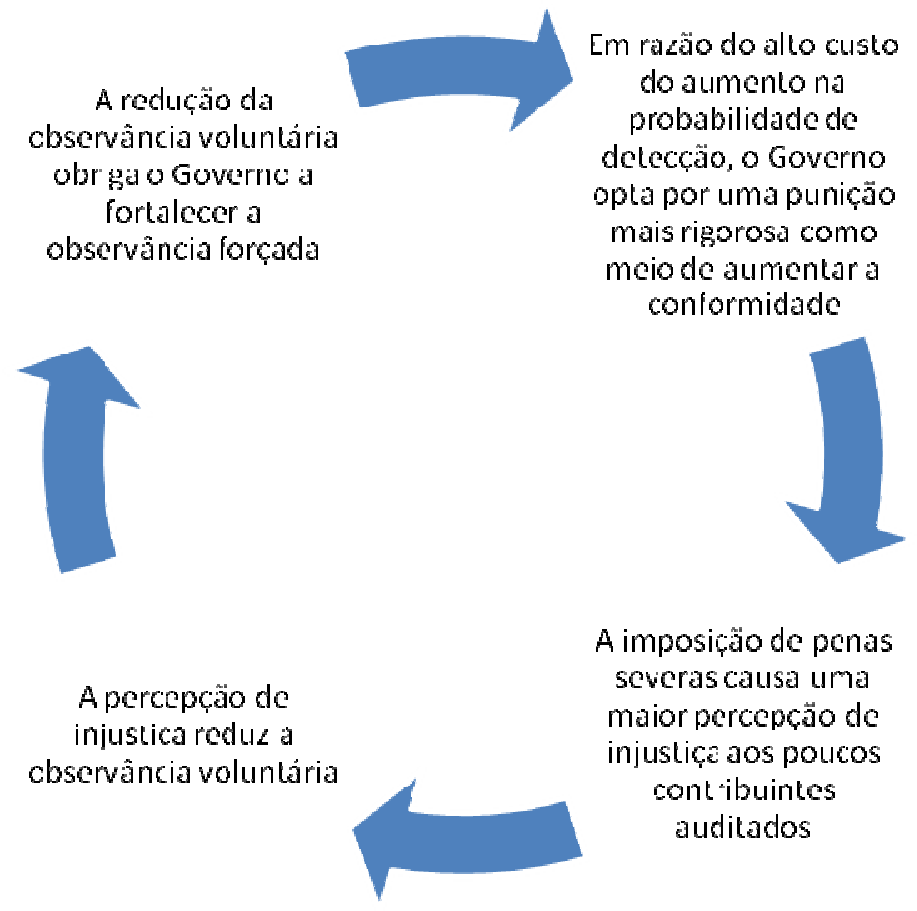

Figura 1 - Ciclo vicioso do aumento do rigor das punições

Fonte: Elaborada pelo autor.

Segundo Alm et al. (2012b), verifica-se um ciclo em que prevalece a alta desconfiança por parte do contribuinte. O resultado desse círculo vicioso é um sistema insustentável, com o aumento de contencioso fiscal e altos níveis de evasão, como parece ser o caso do Brasil.

Há que se levar em conta, ainda, que nem sempre o contribuinte adota atitudes visando, conscientemente, sonegar tributos (Leviner, 2008). Há casos em que o indivíduo se equivoca na interpretação da lei, especialmente devido à grande complexidade da legislação tributária. Nesses casos, a imposição de penas severas torna-se particularmente perturbadora 
(Leviner, 2008), renovando o sentimento de injustiça do contribuinte e prejudicando ainda mais a observância voluntária. Braithwaite (2011) acrescenta que a punição e o tratamento desrespeitoso daqueles que agiram de acordo com a lei afeta a moral tributária do contribuinte, o que dificulta a percepção de legitimidade das autoridades.

Feita essa análise, é natural concluir que a melhor opção para combater a evasão fiscal é o aumento da probabilidade de deteç̧ão, e não do peso da punição, reverberando aquilo que há muito foi percebido por Beccaria (1764/2012) e Skinner (1974/2006). Minimamente, conforme defende Leviner (2008), a abordagem sugerida é o aumento da probabilidade de detecção e a severidade da punição como estratégias complementares, ao invés de se optar por substituições extremas.

Ocorre que, conforme mencionado, o aumento da probabilidade de deteç̧ão acarreta altos custos, de modo que esses investimentos certamente impõem árduas escolhas ao Governo, que, para aumentar a arrecadação, deve investir elevadas quantias que poderiam ser aplicadas em outras áreas estratégicas, como saúde e educação, representando claro dilema de trade-off. Como resultado, as políticas públicas visando ao combate à sonegação fiscal ou qualquer outra conduta ilegal, inserem-se em um problema ainda mais abrangente, que é a dificuldade de alocação ótima de recursos públicos, como oportunamente mencionou Becker (1968).

O combate à sonegação fiscal é tema tão complexo, que, mesmo superada a dificuldade de financiamento dos recursos necessários para o aumento da probabilidade de deteç̧ão, surgem outros problemas na implementação dessa política. É que o aumento da presença de fiscais na vida dos cidadãos também apresenta graves efeitos colaterais. Müehlbacher et al. (2011) alertam que embora os controles rígidos e punições possam promover a observância forçada, acarretam atitudes negativas por parte dos contribuintes. Interessante notar que Skinner (1974/2006) já havia se apercebido disso ao afirmar que o controle realizado pelo Governo de maneira aversiva faz com que os cidadãos adotem práticas de contracontrole, 
procurando esquivar-se desse poder. Segundo o autor, o sofrimento causado pelo controle causa amargura nos indivíduos, afetando sua eficiência. Em tese, portanto, o excesso de poder e controle pode gerar uma reação de contracontrole para evitá-lo, tema que será mais debatido oportunamente.

Sintetizando, embora haja certo consenso de que aumentar a probabilidade de deteç̧ão constitui política superior ao simples aumento da severidade da punição, aquela prática também tem o potencial de acarretar efeitos perversos em termos de conformidade fiscal, especialmente aquela dita voluntária, o que revela os diversos pontos negativos do "paradigma do crime".

Por outro lado, a abordagem do "paradigma do serviço", em que o clima de confiança entre contribuintes e autoridades cria um ambiente cooperativo que afeta positivamente a arrecadação tributária, pode ser uma alternativa eficiente para o combate da sonegação fiscal. Em um Estado policialesco, por exemplo, o foco são os contribuintes que adotam decisões racionais, ou seja, procuram maximizar seu lucro. Em um Estado orientado para o serviço e bem-estar, o foco é a cooperação entre os atores sociais, criando-se um clima de confiança que afeta positivamente a observância fiscal voluntária, sem a necessidade de altos investimentos para o aumento da probabilidade de deteç̧ão e sem os efeitos deletérios das sanções (Kirchler, 2007).

Realmente, a premissa de que o contribuinte obedece à legislação fiscal quando é tratado adequadamente e quando reconhece que o pagamento de tributos gera contraprestação por parte do Estado através de serviços públicos de qualidade é bem aceita pela comunidade científica (Alm \& Torgler, 2011; Kirchler, 2007), haja vista que essa abordagem reforça a confiança e, como consequência, a observância voluntária. Daí, é natural concluir que o Governo poderia controlar de modo eficaz o nível de observância fiscal, adotando políticas mais consistentes com o "paradigma do serviço". 
Posner (2000) inclusive assinala que em locais em que o Governo é pouco aprovado, a observância fiscal será reduzida. Contudo, o autor alerta que modificar esse quadro por um custo razoável talvez não seja possível sem primeiro ou simultaneamente reformar o Governo. Dito de outra forma, nem sempre isso é viável em curto e médio prazo, na medida em que também exige investimentos e, igualmente, acarreta alto custo, o que, consequentemente, gera novos desafios de escolhas.

Tem-se, portanto, um dilema ainda mais complexo. Isso porque havendo um alto clima de confiança entre autoridades e cidadãos, verifica-se um alto nível de observância voluntária, que não gera demasiado custo ao Governo, pois o nível de conformidade é elevado independentemente do investimento na implementação de auditorias e na aplicação de punições. Há que se considerar, contudo, que para se atingir esse clima de confiança é preciso que o contribuinte seja tratado como um "cliente", recebendo contraprestação em serviços públicos de qualidade, como pressupõe o "paradigma do serviço", o que exige tempo e, igualmente, altos investimentos governamentais.

Deve-se ter em mente, ademais, que cada indivíduo tem suas próprias concepções acerca do cumprimento de suas obrigações tributárias, havendo uma notável diversidade de comportamentos (Alm \& Torgler, 2011). O "paradigma do crime" tende a ver o contribuinte como único, sempre motivado pelo benefício econômico individual, o que, segundo Alm et al. (2012a, 2012b), é um equívoco, eis ser evidente que, em se tratando de observância fiscal, não estamos diante de um grupo homogêneo. Dessa forma, os fatores que influenciam a atitude dos contribuintes são diversos, indo desde o comportamento utilitarista racional, até mesmo o pagamento por simples altruísmo, ética, moral, dentre outros fatores, sendo múltiplas as motivações do indivíduo (Alm \& Torgler, 2011; Leviner, 2008). Em razão disso, inclusive, Alm (2012) reconhece que os comportamentos dos contribuintes são variados, de modo que não podem ser capturados por uma única metodologia. 
Braithwaite $(1995,2003,2009,2011)$ dá uma exata noção do quão equivocado é adotar uma estratégia homogênea para todos os cidadãos. Segundo a autora, as posturas motivacionais de cada indivíduo diferem, sendo que em seus estudos identificou cinco delas, sendo duas positivas (compromisso e sujeição) e três negativas (resistência, distanciamento e disposição para o jogo $)^{13}$.

A autora explica o que caracteriza cada uma dessas posturas motivacionais. Compromisso reflete a confiança do contribuinte no sistema fiscal e o sentimento moral de colaborar de boa-vontade com sua quota-parte no interesse da coletividade. Trata-se da crença de que o sistema deve ser suportado por todos. Sujeição reflete a aquiescência ao poder da administração fiscal como a autoridade legítima, bem como a percepção de que se trata de um poder benévolo, desde que o indivíduo aja de forma apropriada. Essas duas posturas são consideradas positivas, favorecendo a observância fiscal, na medida em que há um alinhamento do contribuinte com o interesse das autoridades.

Na outra ponta, estão as três posturas motivacionais negativas, chamadas pela autora de posturas de desafio, que prejudicam a observância fiscal, já que o contribuinte demonstra sua discordância de agir da maneira desejada pelas autoridades. A resistência caracteriza-se pelas dúvidas dos contribuintes sobre as reais intenções da administração fiscal no sentido de se comportar de forma cooperativa, gerando nos indivíduos a percepção de que devem adotar uma postura cuidadosa ou até mesmo hostil, para se contrapor à coerção imposta pelas autoridades. $O$ distanciamento se relaciona com a resistência, mas nesse caso há uma sensação de desencanto generalizado com as autoridades, levando os contribuintes a não cooperar nem sequer demonstrar preocupação com a observância fiscal. Na disposição para o jogo, o contribuinte adota uma postura combativa, parecendo refletir o prazer de desafiar a autoridade fiscal, avaliando brechas e modos de reduzir o montante a ser pago em impostos.

\footnotetext{
${ }^{13}$ Tradução livre de commitment, capitulation, resistance, disengagement, game playing, respectivamente.
} 
Considerando-se, portanto, as cinco diferentes atitudes e crenças dos contribuintes reveladas acima, as respostas das autoridades deveriam ser adaptadas de acordo com as diferentes categorias e características dos contribuintes (Kirchler, 2007). Braithwaite (2009) defende que as autoridades devem ser rigorosas ao lidar com sonegadores contumazes, ao passo que diante de indivíduos que adotem uma postura motivacional positiva, a ação deve ser no sentido de educar, assistir e oferecer suporte, entendimento endossado por Müehlbacher et al. (2011). Assim, é fundamental que as autoridades adaptem suas respostas para atingir um contingente mais abrangente de contribuintes (Lemoine \& Roland-Lévy, 2012), cujas motivações em face das autoridades administrativas variam, de modo que parte da sociedade reconhece a necessidade e as vantagens dos tributos, porém esse senso de comunidade não é partilhado por todos (Alm et al., 2012a).

Leviner (2008) igualmente trata do tema ao sustentar que compete aos agentes públicos oferecer cooperação aos contribuintes, visando reduzir ou evitar sensações de ressentimento, antagonismo e desconfiança. Afirma que essa atitude promove uma conexão entre contribuintes e agentes públicos, o que eventualmente evoca observância voluntária. Todavia, adverte que, quando tais práticas não são suficientes para se obter a observância voluntária, os agentes públicos devem ser firmes, porém justos, o que demonstra que as ferramentas do "paradigma do crime", apesar de seus efeitos deletérios, não podem ser descartadas. Em outras palavras, o autor diz que a questão não é se as autoridades tributárias deveriam punir ou anistiar os contribuintes, mas sim como isso deveria ser posto em prática de uma forma que previna resistência e fortaleça a cooperação.

Opinião equivalente é a de Alm et al. (2012a), sustentando que para alguns a punição pode não ser necessária, porém tratar as "ovelhas negras" com aquilo que chamaram de "cenoura doce" não é eficiente. Desse modo, diferentes estratégias devem ser postas em prática, possibilitando que as autoridades lidem com diversas espécies de comportamento dos contribuintes (Alm et al., 2012b). 
Mais a mais, corporifica-se, pois, a ideia de que, se por um lado as autoridades tributárias devem fortalecer a cooperação junto aos contribuintes, no sentido de aumentar a observância voluntária, por outro, devem ser firmes com os sonegadores contumazes, conforme defende Leviner (2008), atingindo, assim, a maior quantidade de indivíduos, cujas posturas em relação à tributação variam enormemente, podendo a sonegação decorrer da máfé ou até mesmo de interpretação errônea da lei, para citar apenas dois exemplos. Inclusive, como aduz o autor, essa postura se faz necessária para encorajar os que obedecem à legislação fiscal, demonstrando que essa é a atitude correta.

A propósito, Geest e Dari-Mattiacci (2013) bordam oportunas considerações afirmando que a utilização exclusiva de punições frequentemente resulta no castigo de contribuintes que não estão capacitados para cumprir a lei. Weigel et al. (1987) registram que também há sonegação em razão de equívocos de memória, erros de cálculo ou mesmo devido a insuficiente conhecimento da legislação fiscal. De outra ponta, segundo os autores, há aqueles que adotam ações deliberadamente voltadas para fraudar o fisco. Tratar ambos os tipos de contribuintes de maneira igualitária não apareta ser isonômico (Skinner \& Slemrod, 1985), sendo que a diferenciação da consequência a ser experimentada por cada um deles pode ser um caminho promissor. Desconsiderar essa distinção tem sérios efeitos adversos, haja vista que o contribuinte que cometeu apenas um equívoco de interpretação, quando tratado como um criminoso, nos moldes do "paradigma do crime", sente-se ainda mais injustiçado e, a partir de então, mais propenso a não colaborar com o fisco, reduzindo a observância voluntária.

Há que se reconhecer, contudo, que na maioria dos casos envolvendo questões tributárias é demasiadamente complexa a distinção entre o contribuinte de má-fé e o de boa-fé (Skinner \& Slemrod, 1985), podendo ser utópico tratar os contribuintes de forma diferenciada (Posner, 2000). Nem sempre é possível concluir se determinado contribuinte deixou de pagar seus tributos em razão de má interpretação da lei ou de forma deliberada, novamente apenas exemplificando. 
Essa dificuldade, todavia, não pode ser justificativa para leniência por parte do Poder Público. Há que serem estudados mecanismos para, ao menos, reduzir o problema, como, por exemplo, aplicação de punições distintas conforme a gravidade e a intenção evasiva (Feld \& Frey, 2007), bem como imposição de multas gradativas conforme o contribuinte reitere as práticas sonegatórias, eis que seguro admitir que a repetição do comportamento é, ao menos, indício de má-fé.

Nessa linha de raciocínio, Ahmed (2005) defende que a aplicação de penalidades deveria ser posta em prática somente depois de as autoridades buscarem a observância fiscal através de práticas educativas e persuasivas. A autora cita, nesse sentido, o Ato Compliance Model $^{14}$, modelo de observância do Governo australiano, que pressupõe o pleno conhecimento por parte da comunidade de que a desobservância tributária resulta em respostas por parte das autoridades, e que essas respostas serão mais duras do que aquelas previamente aplicadas.

Ademais, a adoção de punições gradativas, conjuntamente com o oferecimento de recompensas para aqueles que agem de maneira escorreita, serve de aprendizado em razão das consequências que cada contribuinte, individualmente, recebe por conta de seu comportamento. Isso torna plausível, em certo grau, distinguir as consequências de cada um.

Há evidências de que tais iniciativas são bem aceitas pela população em geral, conforme informa Devos (2008). Em estudo realizado na Austrália, o autor concluiu que os resultados são consistentes com a literatura do "stick and carrots", demonstrando que há preferência por uma abordagem mais positiva e educativa, em contraposição àquela exclusivamente punitiva.

Dessa forma, seja pelos dilemas de escolha acima discutidos, seja em razão da constatação de que os contribuintes não formam um grupo singular e homogêneo (Alm et al., 2012a), emerge como caminho promissor a integração dos paradigmas "do crime" e "do

\footnotetext{
${ }^{14} \mathrm{O}$ Ato Compliance Model pode ser consultado em https://www.ato.gov.au/About-ATO/About-us/How-we-dothings/Compliance-model/. Acessado em 29 de março de 2015.
} 
serviço". O referencial teórico sustenta a tese de que através da adoção das ferramentas mais propícias de cada um e alocação de recursos mais eficiente é possível aumentar a observância fiscal. Conforme a confiança dos contribuintes for gradativamente aumentando, e, consequentemente, a observância fiscal voluntária, seria possível ir reduzindo o manejo das ferramentas do "paradigma do crime", sem que isso afetasse o nível de arrecadação tributária, haja vista que a observância voluntária compensaria a observância forçada.

Nessa linha, como bem averbado por Alm e Torgler (2011), a adoção de estratégias considerando o "paradigma do crime" pode ser um bom ponto de partida para o controle da evasão fiscal, porém, paulatinamente, há necessidade de adoção de outras estratégias, mais alinhadas com o "paradigma do serviço". Alm, Sanchez e Juan (1995), da mesma forma, afirmam que detecções e punições são estratégias iniciais razoáveis, porém defendem ser necessária uma abordagem multifacetada, que enfatize o enforcement, sem deixar de lado outras estratégias, inclusive o uso de recompensas.

Corroborando este entendimento Leviner (2008) assinala que a análise do paradigma econômico serve de estratégia inicial para a compreensão do comportamento do contribuinte, porém isso pode levar a um sistema excessivamente punitivo, que pode ser contraproducente, devendo serem considerados outros fatores que não apenas o desejo do contribuinte de aumentar sua utilidade, balanceando as estratégias de combate à evasão fiscal. Kastlunger, Lozza, Kirchler e Schabmann (2013) compartilham a mesma opinião.

Em virtude dessas considerações teóricas, a integração dos paradigmas "do crime" e "do serviço" aparenta ser uma alternativa válida para se atingir a maioria dos indivíduos e possibilitar que as autoridades adotem diversas estratégias de combate à evasão fiscal, considerando as características heterogêneas dos contribuintes e os custos envolvidos no incentivo à observância voluntária e à observância forçada. Trata-se, portanto, de estratégias que se complementam, sendo as ferramentas de coerção postas em prática quando não se verificar a observância voluntária (Leviner, 2008). Conforme defende Lederman (2003), na 
medida em que os comportamentos dos contribuintes são heterogêneos, alguns responderão melhor às estratégias de coerção, enquanto outros serão mais sensíveis a apelos normativos.

Em epítome, considerando-se os apontamentos teóricos aqui abordados, pode ser um equívoco deixar de fazer uso de estratégias decorrentes do "paradigma do crime", inobstante seus efeitos deletérios. Iniciativas no sentido de aumentar o cerco aos contribuintes através de auditorias, ferramenta típica do "paradigma do crime", demonstram bons resultados, como é o caso verificado nos EUA (Leviner, 2008). No Brasil, igualmente, a Secretaria da Receita Federal reconhece que a melhora da fiscalização gerou aumento da arrecadação tributária ${ }^{15}$. No entanto, conforme asseveram Alm e Torgler (2011), as fiscalizações e punições devem estar presentes, sendo, porém, necessária a utilização de outras ferramentas, como o fornecimento de melhores serviços aos contribuintes, como propaga o "paradigma do serviço". Dito de outra forma, trata-se de balancear as políticas tributárias lançando mão das ferramentas disponíveis de ambos os paradigmas, já que, individualmente, ambos aparentam ser limitados, especialmente considerando a complexidade do ambiente econômico atual, que impossibilita qualquer receita uniforme de política tributária (Siqueira \& Ramos, 2005).

Ao agir dessa forma, o Governo poderia evitar custos na coerção dos contribuintes, já que parte deles obedeceria voluntariamente à lei, de modo que os recursos seriam mais eficientemente alocados se direcionados para os indivíduos mais propensos a sonegar (Leviner, 2008).

Sintetizando essa análise, parece inadequado avaliar de maneira maniqueísta o paradigma do "crime" ou o do "serviço". Isso porque não há uma estratégia única e dominante que garanta sucesso no controle da observância fiscal (Alm et al., 2012a). Mostra-se mais promissora, conforme revela o Estado da Arte da pesquisa sobre observância fiscal, a integração dos dois paradigmas, possibilitando ao Estado o manejo das suas diversas ferramentas conforme o contexto social apresentado. Todo esse referencial teórico sugere que,

\footnotetext{
${ }^{15}$ Disponível em http://www.receita.fazenda.gov.br/Memoria/irpf/historia/hist1940a1943.asp. Acesso em 19 de abril de 2014.
} 
em certas circunstâncias, as ferramentas do "paradigma do crime" serão mais adequadas, enquanto em outras oportunidades as estratégias que levem em conta fatores psicológicos, como é o caso do "paradigma do serviço", mostrar-se-ão mais eficientes.

Não se trata, portanto, de saber qual paradigma é mais eficiente, mas, sim, quando e como utilizar cada uma das ferramentas propostas por eles em busca de mais observância fiscal, sendo ingênuo acreditar numa solução exclusiva para o problema da sonegação (Sayeg, 2003). Para tanto, mostra-se imprescindível a aplicação dos princípios da Análise do Comportamento, o que é proposto na sequência.

\subsection{O Behaviorismo Radical}

No presente estudo, o comportamento do contribuinte também será avaliado pela ótica do Behaviorismo Radical, em especial baseado na obra de Skinner, considerado seu precursor e maior expoente (Borges \& Medeiros, 2007). Segundo o próprio Skinner (1974/2006), o Behaviorismo Radical era, na verdade, a filosofia da ciência do comportamento humano.

Essa filosofia foi denominada Behaviorismo Radical por se ocupar de questões relacionadas ao comportamento. $\mathrm{O}$ adjetivo "radical", por sua vez, é incorporado para qualificar essa filosofia, conforme esclarece Baum (2011) ao dizer que o que torna o Behaviorismo Radical "radical" é a consideração de que a ciência behaviorista pode ser uma ciência natural. Carvalho (2002), melhor explicando, relata que Skinner incorpora em sua filosofia fenômenos que são subjetivos, sem, contudo, valer-se de conceitos e explicações mentalistas ou sensações que somente o indivíduo poderia relatar, procurando tratar a ciência do comportamento como natural.

Segundo apontam Moreira e Hanna (2012), o behaviorismo teve início a partir da obra de John Broadus Watson publicada em 1913, intitulada "A Psicologia como um behaviorista a vê". Afirmam os autores que o trabalho de Watson continha críticas à linha de pesquisa 
experimental que procurava demonstrar a Psicologia como ciência natural, em especial devido à dificuldade de replicação de resultados de experimentos com humanos quando usada a introspecção experimental.

Baum (2006) dá conta de que Watson censurava o uso da introspecção presente nas pesquisas experimentais, em que a diferença entre os resultados era atribuída à dificuldade dos participantes de realizar observações precisas de seus estados mentais, ou seja, as pesquisas eram muito dependentes do indivíduo observado, sendo que qualquer falha na reprodução dos dados era imputada ao observador, e não às condições experimentais. Watson sugeria, como contraponto, que a Psicologia deveria ter como mote a previsão e controle do comportamento e que a pesquisa experimental deveria se ocupar da conduta observável, em que a manipulação do ambiente seria seguida de avaliação dos efeitos nos indivíduos (Hübner \& Moreira, 2012). O autor negava a utilização de termos tradicionais relacionados à consciência e mente, evitandose o subjetivismo, de modo que o mote dos estudos da ciência do comportamento seriam apenas aqueles objetivamente observáveis (Baum, 2006).

Inspirado nas ideias de Watson, Skinner desenvolve o ramo da Psicologia denominada Análise do Comportamento, com base na Filosofia do Behaviorismo Radical. A proposta de Skinner, segundo Moreira e Hanna (2012), é que eventos psicológicos privados, como é o caso do pensamento e consciência, sejam reconhecidos como parte do objeto de estudo do comportamento, sendo avaliados com o mesmo rigor científico que ocorre com os eventos públicos. Nas palavras de Baum (2006, p. 44, 46), no Behaviorismo Radical não há distinção "entres os mundos subjetivo e objetivo" no que se refere a suas dimensões. Ambos são entendidos como físicos, não sendo fenômenos de naturezas diferentes. Isto é, o Behaviorismo Radical rejeita o "dualismo de mundo interno e externo".

Skinner, ainda, cunhou o termo "condicionamento operante", ou seja, aquele em que o comportamento produz consequências no ambiente e é por elas afetado, propiciando a aprendizagem do organismo (Borges \& Medeiros, 2007). Segundo Sidman (1989/2009), a 
consequência tem o poder de controlar o comportamento na medida em que determina a probabilidade de agirmos da mesma forma novamente. Trata-se de verdadeira correlação entre eventos, na qual um estímulo do ambiente altera a probabilidade de que um organismo emita determinada resposta (Goulart, Delage, Rico, \& Brino, 2012).

Em assim sendo, as consequências no ambiente passariam a influenciar o comportamento futuro. Conforme ensinam Borges e Medeiros (2007), as consequências determinam, em algum grau, a frequência comportamentos, ou se eles voltarão a se repetir.

Com base nesses conceitos é que, segundo Sidman (1989/2009), a ciência do comportamento procura descobrir o que faz com que certas atitudes humanas sejam mais ou menos frequentes.

São essas as premissas básicas do Behaviorismo Radical, filosofia que embasa a ciência do comportamento, e que tem como mote não apelar para estados mentais e subjetivos como justificativas ou causas de determinado comportamento. Esses estados "internos" são, na verdade, parte do comportamento a ser explicado.

\subsubsection{Seleção pelas consequências}

Moreira e Hanna (2012) afirmam que, com o passar dos anos, Skinner reformulou parte de suas concepções sobre o Behaviorismo Radical, em especial adotando um arquétipo explicativo da teoria, baseada mais no modelo das ciências biológicas do que nas físicas. Os autores assinalam que, influenciado por Darwin e sua teoria da evolução das espécies por seleção natural, Skinner sustentava que o comportamento deriva de um modelo de seleção por consequência.

Darwin (1859) estabeleceu os importantes processos básicos de variação e seleção. 0 primeiro deriva da constatação de que cada espécime é única, variando em certo grau quando 
comparada com as demais. Adaptados ao ambiente em que vivem, todos esses seres têm condições de sobrevivência, e suas características se mantêm inalteradas.

Contudo, quando há uma alteração ambiental, entra em operação o que o autor definiu como seleção. Os seres capazes de se adaptar às novas condições, em razão de suas características particulares, têm mais probabilidade de sobrevivência, sendo, portanto, selecionados pelo ambiente. Dado que sobrevivem aqueles com determinadas características, as quais são melhor adaptadas ao novo ambiente, são estes que irão reproduzir-se. Dessa forma, conforme leciona Baum (2006), grande parte da composição genética de um indivíduo é herdada após ter sido selecionada ao longo das gerações, o que ocorre em virtude de o comportamento escolhido ter contribuído para adaptação e reprodução da espécie em condições de mudanças ambientais. Conforme mencionam Moreira e Hanna (2012, p. 5), "dizer que o ambiente selecionou uma característica é o mesmo que dizer que ela se tornou mais frequente".

Esse seria, para Skinner (2007), o primeiro nível de seleção por consequência. É ele o responsável pela seleção de espécies e explicação para diversos comportamentos (Moreira \& Hanna, 2012). Assim, determinada característica poderia ser mais adequada a um determinado ambiente em adaptação, servindo de suporte para sua sobrevivência. Exemplificando, Moreira e Hanna (2012) citam o caso de lobos que têm mais agilidade e que, em razão disso, têm mais fácil acesso à presa, o que garante a sua sobrevivência em detrimento daqueles mais lentos. Diz-se, nesse caso, que o ambiente selecionou a característica agilidade.

O segundo tipo de seleção por consequência refere-se ao condicionamento operante. Nesse nível, o comportamento é influenciado por suas consequências, que modificam a probabilidade de ele se repetir no futuro em um contexto semelhante (Baum, 2006; Skinner, 1953/2003). Isso decorre da lei do efeito, segundo a qual, quanto mais o comportamento é reforçado, maior é a sua tendência de se repetir, e quanto mais ele é punido, maior é a tendência de não voltar a ocorrer (Baum, 2006). Por isso que, conforme ensinam Goulart et al. 
(2012), a consequência para determinada resposta, que faz com que respostas dessa classe aconteçam com maior frequência, no futuro, é denominada consequência reforçadora. Quando, por outro lado, a consequência faz com que a classe de respostas se enfraqueça, e aconteça com menor frequência no futuro, a consequência é denominada punitiva.

Logo, os comportamentos são selecionados por suas consequências. Segundo Baum (2006), as atitudes bem-sucedidas são reforçadas, enquanto as atitudes malsucedidas são punidas. Isso faz com que o comportamento bem-sucedido seja selecionado por suas consequências, eis que o reforço aumenta a probabilidade de repetição da ação, ao contrário do que ocorre com a punição. Dito de outra forma, o comportamento bem-sucedido foi selecionado em detrimento do comportamento malsucedido.

Há que se destacar a importância do contexto envolvido nessa análise. A Análise do Comportamento tem como modelo de avaliação, no paradigma operante, a tríplice contingência ${ }^{16}$, representada por um estímulo antecedente envolvendo um determinado contexto, uma resposta comportamental e o estímulo consequente (Moreira \& Hanna, 2012). Quando esse estímulo consequente é um reforço, a probabilidade de o comportamento se repetir, no mesmo contexto, é maior. Quando se trata de um estímulo punitivo, como já dito, dá-se o contrário.

Também há que se destacar a existência de uma linha tênue que diferencia o primeiro do segundo nível de seleção por consequência. Skinner (1974/2006) relata que algo é reforçador porque é agradável aos sentidos, ao passo que pela teoria da evolução o reforço está ligado ao seu valor de sobrevivência, e não às sensações correlatas. Moreira e Hanna (2012) complementam, explicando que a seleção natural tem como consequências mudanças nas espécies, as quais são selecionadas em longos períodos, ao passo que o condicionamento

\footnotetext{
${ }^{16} \mathrm{Na}$ análise do comportamento, o termo "contingência" é usado para designar uma relação de dependência entre enventos (Moreira \& Hanna, 2012). Quando é dito, por exemplo, que uma resposta é seguida por determinada consequência, que altera sua probabilidade futura de ocorrência, significa que esta resposta e esta consequência estão em uma relação de contingência.
} 
operante se refere mais ao nível particular, relacionando-se com eventos ocorridos durante a vida de cada indivíduo.

O condicionamento operante seria, então, o responsável pelo comportamento individual. A opção pelo termo "operante" se deve ao fato de que o comportamento opera sobre o ambiente gerando determinadas consequências (Skinner, 1953/2003). Há ainda que se esclarecer que no condicionamento operante o ambiente é referido não como o universo do qual participa o organismo, mas tão-somente como um conjunto de eventos que exercem influência no seu comportamento (Moreira \& Hanna, 2012).

É sobremodo importante assinalar que o condicionamento operante decorre de uma intrincada rede de interações com o ambiente e outros seres, da mesma espécie ou de outra, influenciando a probabilidade de esse mesmo comportamento se repetir no futuro. Quando há o fortalecimento de determinado operante, a ocorrência de determinada resposta se torna mais provável (Skinner, 1953/2003). Imaginemos, por exemplo, um cão que ao se aproximar de um estranho receba um afago, enquanto outro, da mesma raça, seja maltratado. A probabilidade do comportamento de se aproximar de um estranho será diferente em ambos os casos. O animal que recebeu uma resposta amável mais provavelmente repetirá seu comportamento no futuro. Já o segundo cão demonstrará mais reticência ao ver um estranho. Trata-se de típico exemplo de aprendizado por consequência que afetou o comportamento particular, provocando mudança de atitude. A mudança da frequência em que aqueles cães se aproximam de um estranho, segundo Skinner (1953/2003), constitui o processo de condicionamento operante. É por isso que, segundo Moreira e Hanna (2012), cada interação com o meio ambiente afeta a maneira de agir, convertendo-se em um processo extremamente dinâmico. Do mesmo modo reflete Baum (2006) ao dizer que todo comportamento é fruto de uma intensa história de reforços no passado.

Sintetizando essa ideia, Skinner (1974/2006) afirma ser o condicionamento operante um processo simples, por meio do qual a consequência de um comportamento altera a 
probabilidade de ele voltar a ocorrer. Skinner (1953/2003) ensina, em outra oportunidade, que no condicionamento operante as variáveis não eliciam ${ }^{17}$ determinado comportamento, mas, sim, tornam sua ocorrência mais provável em condições semelhantes no futuro. É dinâmico, contudo, porque o comportamento do organismo é influenciado por incontáveis interações, que, por sua vez, modificam a sua probabilidade de voltar a ocorrer, dependendo de suas consequências.

Skinner (1953/2003) favorece a compreensão do condicionamento operante quando afirma que não se diz que o homem se comporta em razão das consequências que decorrem de um comportamento, mas, sim, que ele se comporta por causa das consequências decorrentes de uma conduta semelhante no passado. Vale dizer que o comportamento não é posto em prática a fim de se obter certa consequência. Não é voltado para o futuro. No âmbito do condicionamento operante, o comportamento se dá em razão de consequências dantes verificadas, dando-se, assim, o processo de aprendizagem.

Skinner (1976/2006) esclarece, ainda, que o comportamento não é um ato reflexo em respostas a certas contingências. O condicionamento operante apenas aumenta a probabilidade de aquele comportamento ocorrer novamente, em razão de a resposta ter sido reforçada. $\mathrm{O}$ autor exemplifica afirmando que a probabilidade de uma pessoa atender a um aviso ou seguir um conselho dependerá do que ocorreu em circunstâncias semelhantes no passado. Se, por exemplo, alguns estudantes são avisados pelo professor da necessidade de estudar para uma prova, pois ela terá um grau de dificuldade elevado, a probabilidade de eles seguirem o conselho variará individualmente, dependendo do que aconteceu com cada um em circunstâncias semelhantes no passado.

Fica evidente, portanto, que a atribuição de importância a certo evento depende de contingências passadas em que episódios semelhantes foram relevantes para o indivíduo (Skinner, 1974/2006). Para ilustrar com um exemplo sobre observância fiscal, um contribuinte

\footnotetext{
${ }^{17}$ Eliviar significa uma resposta automática em razão de um estímulo.
} 
pode dar pouca importância à sonegação fiscal, se no passado atos semelhantes não acarretaram consequências punidoras. Isso sugere que a punição de atos evasivos pode ser importante no combate à sonegação fiscal, por acarretar uma consequência "desagradável" que o contribuinte, possivelmente, procurará evitar no futuro.

Skinner (1953/2003, 1981/2007) sustenta ainda que a compreensão do comportamento humano não se encerra na análise do primeiro e do segundo nível de seleção por consequência. O autor dá conta da existência de um terceiro nível, qual seja, o nível de seleção cultural.

De acordo com Skinner (1974/2006), as contingências culturais se caracterizam como reforços mantidos por um grupo ou sociedade, na medida em que certas práticas criam consequências para seus membros, reforçando de alguma forma o comportamento. Trata-se de uma visão diversa do que comumente se conhece de cultura, no sentido de um conjunto de costumes, maneiras, valores e ideias. Para Skinner (1974/2006), a cultura representa um conjunto de contingências de reforços mantidos por determinado grupo que formam um padrão de comportamento local, entendimento semelhante ao de Baum (2006). Melo, Garcia, Rose e Faleiros (2012) complementam essa definição ao afirmar que a cultura são os costumes de um grupo de indivíduos.

A seleção cultural completa os três níveis de seleção por consequência abordados por Skinner aos quais o homem está sujeito: seleção natural (nível filogenético), seleção por condicionamento operante (nível ontogenético) e seleção cultural (Moreira \& Hanna, 2012).

A despeito de tratar dos três níveis de seleção por consequência, a Análise do Comportamento concentra seus esforços no entendimento mais detalhado do segundo nível de selação: o condicionamento operante. Para melhor compreensão do que Skinner chamou de ontogênese (condicionamento operante), é indispensável o entendimento dos conceitos: reforçamento e punição. 


\subsubsection{Reforçamento e punição}

O segundo nível de seleção por consequência - seleção por condicionamento operante - revela que os comportamentos podem ser influenciados, ainda que com efeitos diversos, por reforços e punições.

Denominam-se reforços as consequências que aumentam a probabilidade de um comportamento se repetir no futuro (Borges \& Medeiros, 2007). Somente pode-se dizer que determinada consequência é reforço quando ela propiciar um aumento da probabilidade de ocorrência do comportamento. Portanto, conforme afirma Sidman (1989/2009), a definição de reforço é funcional, ou seja, um ato é reforçador se ele torna mais provável a repetição do comportamento reforçado em circunstâncias análogas.

Nesta linha, um mesmo estímulo apresentado como consequência poderá ser um reforço ou uma punição, dependendo do indivíduo e do contexto envolvido. Desse modo, por exemplo, chocolate por ser algo extremamente reforçador para determinada pessoa, mas ser uma consequência aversiva para outra. Além disso, conforme esclarece Baum (2006), algo não será reforçador durante todo o tempo, como, no caso do exemplo, uma pessoa saturada por ter comido muito chocolate, ocasião em que esse alimento não mais se mostra reforçador. 0 autor diz que, inclusive, o alimento pode ser punidor, caso o indivíduo tenha exagerado na dose. Portanto, a análise deve ser funcional, isto é, não se pode dizer se determinada consequência é ou não é um reforço: somente se houver um aumento da probabilidade de ocorrência do mesmo comportamento no futuro, estar-se-á diante de um reforço. Assim, dependendo do contexto, determinada consequência poderá exercer função reforçadora ou punitiva (Goulart et al., 2012).

O reforço, por sua vez, é chamado de positivo quando a modificação produzida no ambiente se refere a adição de um estímulo, como ocorre, por exemplo quando se oferece um doce a uma criança que se comporta adequadamente (Borges \& Medeiros, 2007). 
Por outro lado, há casos em que um estímulo é excluído do ambiente. Esse tipo de reforço, embora também aumente a frequência da ocorrência de determinado comportamento, é chamado de reforço negativo, justamente em razão da retirada e não adição de um estímulo do ambiente (Borges \& Medeiros, 2007). Trata-se, nesse caso, de um estímulo aversivo presente no ambiente, e que, ao ser eliminado como consequência de determinado comportamento, reforçara a resposta que o removeu.

Melhor esclarecendo essa distinção, Sidman (1989/2009) ensina que o reforçamento positivo é aquele em que o comportamento é seguido pela adição de algo novo no ambiente, ao passo que no reforçamento negativo o comportamento tem como consequência a subtração ou eliminação de um estímulo aversivo. $O$ autor resume afirmando que se obtém algo quando se é reforçado positivamente e se esquiva quando reforçado negativamente. Um ou outro, contudo, é denominado reforçador porque aumenta a probabilidade de emissão daquele comportamento.

Sidman (1989/2009) arremata qualquer dúvida ao afirmar que a distinção fundamental entre reforço positivo e reforço negativo é o fato de que no reforçamento negativo o indivíduo experimenta uma sensação de alívio, ou seja, que algo desagradável foi interrompido. Por sua vez, no reforçamento positivo a sensação não é de alívio, mas, sim, de satisfação.

Ao seu turno, há consequências que reduzem a probabilidade de ocorrência de um comportamento, que são chamadas de consequências aversivas ou punidoras. Sidman (1989/2009) aduz que a punição refere-se a "contrapartes simétricas de reforçamento positivo e negativo" (p. 59). Em outras palavras, o autor assinala que a punição acarreta a retirada ou interrupção de um reforçador positivo ou a produção de algo que seria um reforçador negativo, sendo ambos os casos contingências aversivas. 
A punição é igualmente diferenciada entre positiva e negativa. A distinção se assemelha àquela do reforço positivo e negativo, residindo no fato de que na punição positiva um estímulo aversivo é acrescentado, ao passo que na punição negativa um estímulo reforçador é retirado do ambiente (Borges \& Medeiros, 2007).

A punição, quando administrada por outro ser humano, em geral tem por objetivo a eliminação de comportamentos considerados inadequados e indesejáveis, baseando-se no princípio de que ela reduz a probabilidade de o comportamento ser repetido (Skinner, 1983). Borges e Medeiros (2007) são mais categóricos, expressamente aduzindo que a punição, seja ela positiva ou negativa, diminui a probabilidade de o comportamento ocorrer ou, como quer Skinner (1953/2003), ao menos destina-se a acabar com ele. Sidman (1989/2009), contudo, discorda dessa análise. Para o autor, a punição não se relaciona com a redução da probabilidade de repetição do comportamento punido, mas simplesmente com a perda de reforçador positivo ou o ganho de negativos. A redução da probabilidade do comportamento usualmente ocorre, mas, segundo o autor, não há a certeza de que essa será a consequência de uma punição.

Apesar da controvérsia, segundo Borges e Medeiros (2007), o controle aversivo também se refere à modificação de probabilidade de ocorrência do comportamento no futuro; todavia, através do reforço negativo há um aumento; e com a punição há redução da probabilidade de sua repetição.

De todo modo, a punição une-se ao reforço negativo, sendo ambos considerados controles aversivos do comportamento (Borges \& Medeiros, 2007).

Nesse passo, o tipo de controle propiciado pelos reforços negativos e punições é denominado aversivo porque o indivíduo se comporta com o fito de que um estímulo desagradável seja retirado do ambiente (reforço negativo) ou nem sequer venha a ocorrer (punição), conforme palavras de Borges e Medeiros (2007). Skinner (1953/2003) aduz que um 
estímulo somente é considerado aversivo quando sua retirada do ambiente reforça o comportamento do organismo. A contrario sensu, se o estímulo é adicionado ao ambiente e acarreta diminuição da probabilidade de o comportamento se repetir, também é possível dizer tratar-se de um estímulo aversivo, dessa feita uma punição.

Tais controles aversivos - reforço negativo e punição - são frequentemente confundidos. Skinner (1974/2006), porém, esclarece que o reforço negativo é uma espécie de punição por não se agir, ou seja, ele é utilizado para gerar um comportamento, ao passo que a punição visa interromper um comportamento.

Borges e Medeiros (2007) trazem diversos exemplos de reforço negativo que facilitam a compreensão do conceito e a distinção da punição. Citam o caso do indivíduo que coloca óculos de sol para reduzir a luminosidade que causa desconforto à retina. Outro exemplo é a ingestão de analgésico visando cessar uma dor de cabeça. Em ambos os casos, a consequência do alívio (retirada de um estímulo aversivo do ambiente) reforça o comportamento, ou seja, aumenta a probabilidade de no futuro o indivíduo utilizar os óculos de sol ou ingerir o remédio quando se deparar com contingencias semelhantes.

Ao seu turno, a punição é facilmente exemplificada. O pai que aplica um castigo ao filho pelo fato de este dizer um palavrão ou o professor que dá uma nota baixa ao aluno que foi pego "colando" na prova são exemplos de punição, em que um estímulo aversivo foi introduzido no ambiente e tem como desígnio reduzir a probabilidade de esses comportamentos se repetirem no futuro.

Sintetizando, tanto o reforçamento positivo quanto o reforçamento negativo e as punições são instrumentos que influenciam o comportamento do indivíduo, cada um ao seu modo. Ocorre, todavia, que o controle aversivo (reforço negativo e punições) acarreta efeitos colaterais indesejados, desaconselhando o seu uso. 


\subsubsection{Os efeitos deletérios do controle aversivo}

No estágio atual da Análise do Comportamento, é bem assentada a opinião de que o controle aversivo, seja por meio de reforçamento negativo ou mesmo pelo emprego de punições, produz efeitos deletérios que fazem com que o reforçamento positivo seja considerado uma ferramenta de aprendizagem mais adequada e vantajosa.

Dentre os efeitos colaterais do controle aversivo verificados com frequência, estão as respostas emocionais eliciadas pelo indivíduo, como é o caso de tremores, taquicardia, choro, medo e temor (Borges \& Medeiros, 2007). ${ }^{18}$

Além desses efeitos emocionais, as práticas aversivas têm como consequência dois comportamentos de contra-controle, efeitos esses que, em geral, são indesejáveis para o agente controlador: esquiva e fuga (Sidman, 1989/2009). As respostas de contracontrole surgem porque a coerção impede que as pessoas se sintam livres ${ }^{19}$, o que é um desejo natural dos seres humanos (Baum, 2006).

Buscando essa sensação de liberdade, o indivíduo emprega a esquiva, que é um comportamento que tem por objetivo impedir ou protelar o contato com o estímulo aversivo (Borges \& Medeiros, 2007). Se o estímulo aversivo já se fizer presente, surge o comportamento de fuga, cujo intuito é retirar ou atenuar esse estímulo do ambiente.

Facilitando essa compreensão, Sidman (1989/2009) relata objetivamente a distinção entre fuga e esquiva. Segundo o autor, na fuga, um evento aversivo acontece antes que

\footnotetext{
${ }^{18}$ Sidman (1989/2009) relata que o controle aversivo acarreta ainda supressão, rigidez, incapacitação, além de sentimentos de violência, agressão, opressão, depressão, ódio, entre outros. (p. 232).

${ }^{19}$ Braithwaite (2011) desenvolve uma ideia semelhante. A autora afirma que a resposta contra qualquer ameaça à liberdade é se opor a ela, tornando-se resistente a esforços de persuasão empregados, por exemplo, pelas autoridades. A autora chama essa postura motivacional de resistência (em tradução livre). De todo modo, a autora adiciona que a liberdade é novamente obtida mantendo-se distância das autoridades, o que nada mais é do que se esquivar do controle aversivo. Kirchler (1997b, 1999) tem entendimento análogo, revelando que a literatura sobre observância fiscal se relaciona intrinsicamente com a Análise do Comportamento, ainda que essa relação não seja normalmente mencionada nos estudos.
} 
possamos escapar. Fugindo, nos livramos de uma situação desagradável. Ao seu turno, na esquiva agimos com antecedência, evitando que algo ruim ocorra e seja necessário fugir.

Uma exemplificação que esclarece essa distinção entre fuga e esquiva é o caso do indivíduo que se submete a uma cirurgia de redução de estômago para emagrecer, procurando retirar do ambiente uma série de estímulos aversivos, dentre os quais problemas de saúde, reprovação social e capacidade física inadequada. De outra ponta, temos aquele que se submete a rigorosa dieta e atividades físicas, evitando ganhar peso e ser submetido àqueles mesmos controles aversivos. No primeiro caso, estamos diante de um comportamento de fuga, na medida em que os estímulos aversivos já estão presentes no ambiente; no segundo, estamos diante de uma esquiva, em que tais estímulos estão sendo evitados.

Na distinção entre fuga e esquiva, também é possível fazer uma analogia ilustrativa com o comportamento do contribuinte nos casos de elisão e evasão fiscal. Na elisão fiscal o contribuinte procura evitar que o fato gerador do tributo ocorra, de modo que não nasça a obrigação tributária. No caso da evasão, ao seu turno, o fato gerador já ocorreu, sendo que o contribuinte visa fugir da obrigação do pagamento do tributo devido. Considerando-se que Borges e Medeiros (2007) afirmam que a esquiva consiste em uma prevenção, ao passo que a fuga seria uma remediação, não é despropositado relacionar elisão fiscal com esquiva e evasão fiscal com fuga. Borges e Medeiros (2007), inclusive, lembram que "prevenir é melhor que remediar" (p. 67) o que também no caso de eventos tributários é verdadeiro; ou seja, a elisão é uma alternativa melhor do que a evasão.

Esse raciocínio favorece que se entenda por que a elisão fiscal é uma prática cada dia mais adotada no Brasil. Segundo Borges e Medeiros (2007), o comportamento de fuga é o primeiro a ser aprendido. Ensinam os autores que não há como explicar um comportamento que ocorre sob o controle de algo que ainda não está acontecendo, exceto se forem avaliados eventos pretéritos. Assim, quando o organismo é apresentado a determinado estímulo aversivo, tende a emitir resposta cujo objetivo é retirá-lo do ambiente; ou seja, adota um 
comportamento de fuga. A esquiva somente irá se tornar um repertório do comportamento do organismo após ele ter passado por uma situação na qual o estímulo aversivo interferiu em seu ambiente, fazendo com que tenda a evitar esse estímulo, por meio da esquiva.

Em outras palavras, o comportamento de fuga é aprendido primeiro, e, com a experiência, o organismo passa a adotar comportamentos de esquiva, na linha do "prevenir é melhor do que remediar". O exemplo oferecido por Borges e Medeiros (2007) possibilita o perfeito entendimento do assunto: o sol forte provoca queimaduras na pele, tornando-se um estímulo aversivo que aumenta a probabilidade de no futuro o indivíduo se comportar de maneira a evitar as queimaduras, utilizando protetor solar, por exemplo. Dizem os autores que foi necessário fugir das queimaduras no passado, utilizando loção analgésica, por exemplo, para aprender que o sol é um estímulo aversivo, e prevenir as queimaduras é a melhor opção ${ }^{20}$. É possível teorizar, portanto, sobre o porquê de a elisão fiscal ser um comportamento cada dia mais comum. Provavelmente, um dos fatores que influenciam esse comportamento foi o contato prévio com estímulos aversivos em razão da prática de sonegação fiscal; ou seja, muita punição gera mais prática de contracontrole, no caso, a esquiva.

Além da fuga e da esquiva, outro efeito deletério do controle aversivo é o fato de que ele acaba por influenciar não apenas o comportamento diretamente punido, mas também aqueles que ocorrem temporariamente próximo à punição (Borges \& Medeiros, 2007).

Sobre o tema, Sidman (1989/2009) relata que o controle aversivo faz com que sejam cessados outros comportamentos que não aquele desejado por quem exerce a coerção, citando o exemplo de um rato que, na caixa experimental, ao pressionar a barra, cessa o recebimento de um choque. Contudo, ao se afastar da barra para investigar um som, o rato acaba por ficar exposto ao choque por mais tempo. Isso faz com que o comportamento de investigar o som seja afetado, embora essa não fosse a intenção do agente que aplicou o estímulo aversivo.

\footnotetext{
${ }^{20}$ É bom que se diga que esse aprendizado não necessariamente ocorre em razão de se ter sofrido queimaduras no passado. O ser humano tem capacidade de aprender por meio de regras, conforme é visto no tópico 2.2.3.
} 
Nesse sentido, Skinner (1953/2003) alerta que um comportamento frequentemente punido pode evocar comportamentos incompatíveis e indesejados. É o caso do contribuinte punido por emitir uma nota fiscal contendo erro material, e que, devido à punição, em vez de adotar mais diligência no cumprimento dessa obrigação acessória, passa a não emitir mais o respectivo documento. Dito de outra forma, a punição, ao contrário do reforço, não serve para estimular um comportamento desejado, mas, sim, para interromper aquele indesejável, porém pode, como consequência, evocar um comportamento disforme e não previsto. Assim, como esclarece Matos (1981), o controle aversivo não suprime, realmente, o comportamento indesejado, mas, sim, tem como efeito a produção de outras respostas que acabam competindo com a resposta punida, cuja função é remover ou atenuar o evento aversivo

Voltando novamente ao tema observância fiscal, pode-se citar o comportamento de um contribuinte que faz uma consulta à Secretaria da Receita Federal visando eliminar uma dúvida tributária, e que, em razão desse comportamento, é punido justamente por não seguir a orientação do órgão fiscal. Como conseqüência, esse indivíduo tenderá a evitar a prática de realização de consulta, ou seja, emitirá respostas diversas para evitar a punição, como, por exemplo, consultar uma empresa de consultoria tributária em vez da Secretaria da Receita Federal. Embora a intenção do órgão tributário fosse punir a sonegação, sua atitude acabou por afetar o comportamento de consulta. Isso pode se tornar ainda mais grave quando a punição foi ou lhe parece injusta, quando tenderá a deixar de praticar aqueles outros comportamentos justamente por não terem sido suficientes para impedir a punição.

Os efeitos podem ser ainda mais graves do que o exemplo acima relatado. Sidman (1989/2009) narra que o controle exercido através de reforçamento negativo torna o próprio ambiente coercitivo, fazendo com que o sujeito procure escapar do próprio ambiente, independentemente da aplicação do reforçamento. Não é absurdo dizer que um empresário, por exemplo, vítima de um excessivo controle coercitivo por parte da fiscalização tributária, pode decidir-se por encerrar seus negócios, fugindo desse ambiente. 
Apesar de todos esses efeitos deletérios, Skinner (1953/2003) afirma ser necessário reconhecer que o controle aversivo é muito presente na sociedade moderna. Isso ocorre porque ele é mais simples de ser colocado em prática do que o reforçamento positivo, especialmente em razão de, conforme aduz Skinner (1953/2003), produzir um efeito imediato, embora o autor ressalve que esse efeito não é duradouro. Do mesmo modo é o escólio de Borges e Medeiros (2007), para quem o controle aversivo tem consequência imediata, especialmente porque a eficácia não depende de privação, além de haver mais facilidade no arranjo das contingências. Os autores aduzem ainda que o controle aversivo é uma forma legítima e eficiente de aumentar ou diminuir a probabilidade de determinado comportamento ser posto em prática. Não deixam de, contudo, alertar que o controle aversivo gera as consequências acima discutidas, de modo que acabam por torná-lo uma prática desaconselhada por muitos profissionais.

Sidman (1989/2009) arremata afirmando que o controle aversivo através da punição produz sérios efeitos colaterais na interrupção do comportamento, que, embora ilusório, é imediato, e isso tem mais influência na conduta daquele que busca o controle.

Baum (2011) dá conta de que a polêmica sobre o emprego do controle aversivo vem de longe, alertando que algumas pesquisas empíricas divergem sobre a eficiência da punição no condicionamento de um comportamento.

Oportuno ressaltar que o próprio Skinner (1974/2006) nem sequer considerava a punição uma ferramenta de aprendizado, dizendo não ser ela tão efetiva como o reforçamento positivo, pois o indivíduo tem certa inclinação para manter a conduta punível ou mesmo se omitir, não sendo empregada a fim de criar um comportamento, ao passo que no reforço busca-se que ele adote determinada conduta.

Skinner (1983) afirma, ainda, que os comportamentos punidos tendem a se repetir tão logo sejam removidas as contingências punitivas. Kirchler (2007) adota posição semelhante ao 
afirmar que através da punição o comportamento é suprimido, e não extinto, de modo que tão logo cesse o castigo, reaparece o comportamento indesejável. Isso impõe que o comportamento indesejado seja sempre punido, sob pena de voltar a se repetir, o que é chamado de recuperação de resposta (Borges \& Medeiros, 2007). Dizendo de outro modo, segundo a concepção de Skinner (1974/2006), a punição não representaria um processo de efetiva aprendizagem, pois o organismo de fato não aprenderia o comportamento apropriado, mas, sim, não se comportaria adequadamente única e exclusivamente para evitar a punição.

Por todos os fatores discutidos, Skinner (1953/2003) é enfático em proferir que o reforço positivo é superior aos estímulos aversivos, na medida em que essa última prática gera ansiedades pertubadoras, incluindo uma tendência de fuga e a esquiva.

Em resumo, muito embora a punição e o reforço negativo sejam práticas que influenciam o comportamento, e que, consequentemente, podem ser empregados no sentido de fortalecer a observância tributária do contribuinte, é preciso se levar em conta seus efeitos deletérios, que podem, inclusive, gerar um resultado contrário ao inicialmente desejado, demonstrando ser imprescindível um conhecimento mais abrangente dos princípios da Análise do Comportamento, para o adequado emprego dessas técnicas.

\subsubsection{Comportamento governado por regras}

Matos (2001) relata que embora em animais o comportamento geralmente seja modelado por contingências naturais, no caso dos seres humanos há também sensibilidade ao comportamento verbal, podendo-se agir de acordo com regras.

Sidman (1989/2009), inclusive, é enfático ao dizer que podemos aprender por meio de regras em substituição às contingências. Nesse sentido, exemplifica afirmando que uma criança não precisa ser atropelada para aprender que não deve correr na rua, bastando um aviso para mantê-la na calçada. 
Segundo Goulart et al. (2012, p. 33), "regras são descrições verbais de contingências", explicação semelhante à oferecida por Matos (2001). Funcionam como estímulos que, potencialmente, evocam respostas no sentido desejado pelo emissor da regra. Essas respostas, de acordo com Goulart et al. (2012), são chamadas de comportamentos governados por regras.

Baum (2006) oferece definição análoga, dizendo que o comportamento governado por regras é aquele regido pelo controle do estímulo regra, sendo esse um estímulo discriminativo verbal que descreve uma contingência, e que governa o comportamento tal como os demais estímulos não verbais, de modo que o indivíduo pode se comportar exclusivamente em razão da regra, independentemente do contato com as contingências.

Goulart et al. (2012) assinala, também, que as regras têm o potencial de criar novos comportamentos, sem que o indivíduo precise ter contato com suas consequências. De acordo com os autores, as regras facilitam a aquisição de novos repertórios comportamentais, de forma mais veloz, ainda que o indivíduo não sofra naturalmente a consequência de seu ato.

Portanto, quando uma lei descreve o ato de sonegar e prevê uma pena para o caso de um indivíduo o praticar, está narrando uma consequência no intuito de influenciar o comportamento; ou seja, a descrição da contingência pode servir para convencer o indivíduo a não praticar o crime justamente visando não sofrer a consequência prevista na lei.

Hübner, Bortoli, Almeida e Cruvível (2012) e Matos (2001) aduzem que a sociedade utiliza as regras como estratégia para obter o comportamento considerado adequado, de modo a compensar a distância entre as consequências aversivas ou reforços positivos e o comportamento. As regras são, portanto, úteis para a vida em sociedade (Matos, 2001). Isso ocorre, reitere-se, porque elas têm o potencial de induzir o comportamento sem que o indivíduo tenha que sofrer as consequências naturais de seus atos. 
Baum (2006) explica, também, que o comportamento controlado por regras estabelece uma relação dupla, sendo de longo prazo, quando justifica a regra, e de curto prazo, quando encoraja o comportamento. Para exemplificar, pode-se citar o caso da prática de exercício físico, em que uma regra estabelece que ao se exercitar, a pessoa pode atingir um nível adequado de resistência física. Essa consequência é um reforço de longo prazo, razão pela qual, para melhor eficiência, um falante pode fornecer reforço imediato ao indivíduo, dizendo coisas como "bom", "certo" e "é por aí" (Baum, 2006).

Skinner (1974/2006), inclusive, reconhece a importância da lei na normatização de condutas, afirmando que as contingências tornam-se mais poderosas quando codificadas, pois indicam para os cidadãos as consequências de determinados atos, de modo que lhes permitem concluir que obedecendo à lei evitarão a punição. Não sendo a lei clara, todavia, perde-se o efeito condicionante. Por isso que o autor ressalva ser fundamental para o aprendizado do indivíduo que ele compreenda as contingências e os efeitos de seus comportamentos. Além disso, devem crer que o ato em prática vai levar a um resultado descrito pela regra.

Caso contrário, a orientação não terá efeito, pois o indivíduo não terá noção exata de qual consequência advirá de determinado ato, o que lhe dificultará a adoção do procedimento correto. Resultado disso, novamente exemplificando dentro do tema deste estudo, será a criação de uma percepção de injustiça fiscal por parte dos contribuintes, o que influencia os níveis de evasão fiscal, como vimos antes. A complexidade das regras, além disso, ocasiona procedimentos equivocados, muitas vezes não decorrentes de um comportamento evasivo consciente, mas, sim, em razão da dificuldade de correta interpretação da norma. Nesses casos, a punição tem um efeito ainda mais adverso, pois em vez de facilitar o aprendizado do contribuinte em razão da consequência desagradável, acaba por gerar uma percepção de injustiça fiscal, reduzindo a observância fiscal voluntária.

A despeito do fato de as regras serem efetivas, Skinner (1974/2006) afirma que há diferença entre praticar o bem porque seu resultado é reforçado e praticar o bem porque a lei 
assim o exige. Segundo o autor, no primeiro caso a pessoa sente-se bem-disposta, ao passo que no segundo o sentimento é de medo de punição, raciocínio que é coerente com os paradigmas do "serviço" e do "crime", respectivamente, conforme visto em capítulo anterior.

O autor esclarece, ainda, que não é aptidão natural do ser humano atender a conselhos ou prestar atenção em avisos (Skinner, 1974/2006). Dessa forma, os estímulos representados por conselhos e avisos dependem de um longo lapso temporal de aprendizado. Dentro dessa compreensão, não é ocioso afiançar que o reforço do comportamento em razão de um estímulo consequente é mais eficaz no controle do comportamento do que uma mera previsão normativa, pois, nesse caso, a regra tem contornos de conselho ou aviso sobre a conduta desejada pelo Governo.

Isso não significa, todavia, que uma lei, por si só, não tenha efeito condicionante. Segundo Skinner (1974/2006), a lei traz um efeito semelhante ao condicionamento por reforço, através da indução; ou seja, revela a consequência do ato, e o indivíduo procura se comportar da maneira indicada para evitá-la. O contato com o reforço, contudo, é mais eficiente para o aprendizado. Imagine, para ilustrar, que uma criança seja advertida que andar descalça em um piso escorregadio pode ter como resultado um tombo. Embora a criança possa inferir a dor que sentirá em caso de queda, a probabilidade de atender ao aviso será tanto maior caso já tenha sofrido o tombo em circunstâncias semelhantes. Esse é o sentido da advertência de Skinner (1974/2006), ao afirmar que a compreensão obtida é usualmente reforçadora quando se passa do comportamento dirigido por regras para aquele modelado pelas contingências.

Nesse sentido, a eficiência de uma regra ao estabelecer um comportamento individual igualmente dependerá das experiências de vida do sujeito (Goulart et al., 2012), o que leva à conclusão de que havendo uma regra que preveja punições contra a sonegação fiscal, sua observância será influenciada conforme os indivíduos, no passado, tenham ou não sofrido as consequências previstas pela norma. 
De todo modo, as regras desempenham papel fundamental na sociedade, ao estabelecerem os comportamentos indesejados e as consequências caso o indivíduo opte por praticá-los. Embora o condicionamento do comportamento seja muito mais efetivo quando o sujeito tem contato com a consequência, as regras mostram-se eficientes na influência sobre os indivíduos, especialmente quando já tiveram experiências que confirmam a consequência das regras.

Tem-se que, conectando-se esses ensinamentos teóricos, as regras também influenciam o comportamento do indivíduo, sendo fundamentais para o controle dos indivíduos em sociedade, embora evidente, porém, que em geral elas envolvem elementos de controle aversivo, quando poderiam, igualmente, prever recompensas, evitando os comportamentos de contracontrole que também estão presentes quando tratamos de regras.

\subsection{0 aprendizado por consequência e os paradigmas do crime e do serviço}

Nesta etapa do estudo torna-se possível estabelecer algumas conclusões, com base nos fundamentos teóricos até aqui abordados. Sinteticamente, a literatura reconhece que o risco de ser auditado e punido é fator de influência do comportamento do contribuinte, em linha com o que leciona o paradigma econômico clássico, que pressupõe a racionalidade do indivíduo, do qual deriva o "paradigma do crime". Essa abordagem, porém, é limitada, sendo que o "paradigma do serviço" demonstra que há muitos outros fatores que afetam o desejo do cidadão de sonegar, como antes mencionado.

Os paradigmas "do crime" e "do serviço", portanto, pressupõem dois tipos de abordagem destoantes por parte das autoridades. No primeiro caso, há uma busca pelo aumento da percepção de risco do contribuinte, recrudescendo a fiscalização e/ou aumentando a severidade das punições, gerando como consequência uma maior observância fiscal forçada. Por outro lado, é possível incentivar a observância voluntária, pressuposto do "paradigma do serviço", especialmente criando-se um clima cooperativo com base na confiança entre 
autoridades e contribuintes. A adoção de ambas as abordagens de forma concomitante, teoricamente é a maneira mais efetiva de combater a evasão fiscal, por proporcionar uma melhor alocação de recursos e atingir grande parte dos indivíduos cujas motivações para pagar tributos variam grandemente, como abordado no tópico 2.1.3.

Da mesma maneira, a Análise do Comportamento demonstra que o comportamento dos indivíduos pode ser influenciado conforme sejam as consequências de seus atos, o que pode ser poderosa ferramenta de incentivo à observância fiscal, o que, aliás, foi notado por Kirchler (2007) e Leviner (2008), ao aduzirem que o comportamento do contribuinte depende de suas experiências fiscais passadas.

Em linhas gerais, inclusive, não é impróprio fazer uma analogia entre os paradigmas "do crime" e "do serviço" e os conceitos da Análise do Comportamento. No "paradigma do crime" busca-se a redução da inadimplência fiscal especialmente através do exercício de forte controle aversivo. Por sua vez, o "paradigma do serviço" tem por objetivo fortalecer uma atitude positiva por parte das autoridades fiscais, aumentando a confiança dos contribuintes no Governo, o que não necessariamente envolve, ou até mesmo é desaconselhado, o uso de práticas aversivas. Para tanto, é necessário que as autoridades demonstrem respeito e gratidão aos contribuintes honestos, o que pode ser feito, por exemplo, oferecendo recompensas aos que cumprem a lei (Kastlunger et al., 2011). Nesse sentido, Torgler (2003a), inclusive, afirma que as recompensas poderiam ser mais eficazes do que as punições, para eliminar comportamentos indesejados ou para motivar o contribuinte a cumprir suas obrigações, o que está em linha com os princípios da Análise do Comportamento.

Conectando-se essas conclusões, é possível teorizar que o Governo pode influenciar a observância forçada e a observância voluntária, por meio da manipulação de consequências que incentive o aprendizado do contribuinte em busca de mais conformidade fiscal, utilizando não apenas punições, mas também recompensas, como, inclusive, afirmam Alm e Torgler 
(2011), muito embora não haja evidências empíricas robustas da efetividade de seu uso, conforme alertam Feld e Frey (2007) e Kastlunger et al. (2011).

Nessa linha, Skinner (1974/2006) sustenta ser possível influenciar o comportamento dos indivíduos modificando o mundo em que vivem. Em outra célebre passagem, o autor afirma que "os homens agem sobre o mundo, modificando-o, e, por sua vez, são modificados pelas consequências de sua ação" (Skinner, 1978, p. 15). Essa influência dá-se em razão do aprendizado pelas consequências, no qual determinando comportamento se torna mais ou menos provável, de acordo com os reforços ou punições recebidas, embora diga o autor que, infelizmente, os mais usados sejam os controles do tipo aversivo, citando particularmente as práticas governamentais, conforme antes abordado.

Skinner (1974/2006) continua dissertando sobre esse raciocínio ao afirmar ser possível rearranjar as contingências positivas e negativas com a intenção de criar interesses, incutir nos indivíduos certos propósitos ou mesmo despertar a consciência.

Do mesmo modo pode fazer o Governo, ou seja, através da engenharia comportamental proporcionar o aprendizado para que objetivos sociais sejam atingidos, sendo essa, segundo Skinner (1974/2006), uma ferramenta poderosa. Não se trata aqui de defender o controle via restrição de liberdade. $\mathrm{O}$ sentido pejorativo da palavra cede espaço para o aprendizado por consequência, através do qual certo comportamento é mais ou menos provável em razão de reforços e punições no sentido de encorajá-los ou dissuadi-los. O Governo pode, por exemplo, incentivar os contribuintes a cumprir as normas tributárias oferecendo prêmios ou ameaçando puni-los, desde que assim o faça adequadamente, sempre ressalvando os efeitos deletérios do controle aversivo.

Interessante notar que a própria Secretaria da Receita Federal cita, em página dedicada a contar a história do imposto de renda no Brasil ${ }^{21}$, um exemplo de aprendizado do

\footnotetext{
${ }^{21}$ (http://www.receita.fazenda.gov.br/Memoria/irpf/historia/hist1997a2006.asp. Acesso em 19 de abril de 2014.
} 
contribuinte através de consequências. Segundo o relato, em alguns exercícios o prazo de entrega da declaração do tributo era prorrogado, e, com isso, parte dos contribuintes já contava com o adiamento e postergavam a entrega da obrigação acessória. Esse procedimento somente foi interrompido em 1996, quanto então foi notado um robusto aumento do contingente de cidadãos que passaram a cumprir o prazo legal. Esse relato ilustra que a própria autoridade fiscal reconhece que adotava prática que afetava o comportamento do indivíduo, que, por saber das prorrogações nos anos anteriores, não cumpria o prazo de entrega da declaração, e que, a partir do momento em que esse prazo deixou de ser dilatado e o contribuinte retardatário passou a ser punido, os índices de atraso reduziram-se substancialmente.

Dessa forma, considerado o referencial teórico até aqui discutido, com o adequado conhecimento dos princípios da Análise do Comportamento, e integrando os paradigmas "do crime" e "do serviço", o Governo poderia obter mais observância tributária. Destaque-se que a sugestão de utilizar a Análise do Comportamento, em especial o comportamento operante, não é original. Kirchler (2007) afirma que o comportamento relativo à observância tributária segue as regras descritas pela teoria do condicionamento operante, embora o autor tenha alertado, surpreso, que desconhece sua aplicação em relação ao tema, o que é proposto no presente estudo.

Contudo, aparentemente as autoridades da administração pública, mormente no caso brasileiro, parecem ignorar essa possibilidade, e muitas vezes, inclusive, acabam por fornecer sinais contraditórios aos contribuintes. Um exemplo que ilustra bastante essa ineficiência ao tentar influenciar o comportamento do contribuinte para que não mais pratique atos de desobservância fiscal são as anistias e os parcelamentos de débitos fiscais oferecidos de tempos em tempos, estratégia que vem sendo há muito adotada por diversos países (Skinner \& Slemrod, 1985). Nesses casos, há uma legislação orientando e exigindo que o tributo seja recolhido em determinados percentual e prazo. Entretanto, o contribuinte desobedece ao aviso, inadimplindo suas obrigações. Embora seja inicialmente punido, futuramente acaba por 
ser agraciado com um parcelamento fiscal, com redução de multas e juros e um longo período para pagamento. A modificação da consequência original prevista em lei prejudica o aprendizado do contribuinte, especialmente porque ele recebe sinais controversos da autoridade pública, ou seja, embora a prática seja passível de punição, é posteriormente perdoada, o que pode erodir a ética do contribuinte, conforme alertam Alm e Torgler (2011).

Skinner e Slemrod (1985) afirmam que essa estratégia tem se revelado eficiente no sentido de arrecadar tributos inadimplidos sem a necessidade de dispêndio de muitos recursos. Alertam, contudo, que ao adotar frequentemente as anistias e parcelamentos o Governo embute nos contribuintes a percepção de que é preferível não pagar os tributos até a próxima oportunidade. Opinião análoga é de Marton (2003), que, inclusive, defende que uma política pública de combate à sonegação fiscal exige, dentre outras providências, que tais práticas sejam abandonadas, por representarem verdadeira afronta aos contribuintes que cumprem suas obrigações fiscais.

Outro não é o entendimento de Posner (2000), que, não obstante reconhecer que há um dissenso sobre os efeitos das anistias, entende ser plausível que delas resultam o aumento da receita no curto prazo, mas também diminui a observância fiscal pela redução na percepção de risco dos contribuintes. $\mathrm{O}$ autor adiciona aduzindo que as anistias são associadas a governos instáveis, que optam pela transferência de receita de futuros governos para o atual, gerando desconfiança por parte dos contribuintes.

Há que se ressaltar, adicionalmente, que o resultado desses programas pode ser ainda mais danoso do ponto de vista do aprendizado do contribuinte. O Governo acaba por premiar o comportamento sonegador, fortalecendo essa prática, ou seja, aumenta a probabilidade de o contribuinte vir a sonegar no futuro. Ainda mais grave, aumenta a sensação de injustiça fiscal, pois aqueles contribuintes que cumpriram com suas obrigações sentem-se desestimulados a manter a atitude correta (Hasseldine, 1998). É o que Skinner (1974/2006) chama de sociedade doente, por haver um conjunto de contingências que produz comportamentos díspares e 
conflitivos: a lei determina que o contribuinte pague seus tributos em dia e, posteriormente, outra regra permite o parcelamento da dívida e oferece descontos que retiram ou suavizam a punição, gerando conduta oposta.

Nesse contexto, não é despropositado imaginar as consequências da divulgação desses programas de benefícios fiscais. Potencialmente, esses "parcelamentos" têm o poder de incutir no contribuinte honesto a sensação de que o comportamento adequado é o oposto, ou seja, a sonegação pode Ihe trazer benefícios em razão da leniência do Governo Federal. Por sua vez, os contribuintes sonegadores podem se sentir laureados justamente pela prática de atos desaprovados pela legislação fiscal. Em outras palavras, ao implementar tais programas de parcelamento fiscal, o Governo beneficia quem agiu em desconformidade com a lei, podendo ocasionar um efeito negativo na observância fiscal, conforme demonstraram empiricamente Alm, McKee e Beck (1990), embora esses autores alertem que esse impacto pode ser compensado se houver mais empenho de enforcement por parte das autoridades logo após a adoção da anistia.

Portanto, em primeiro lugar mostra-se acertada a integração dos paradigmas "do crime" e "do serviço", conforme já abordado. Ademais, revela-se imprescindível às autoridades o conhecimento dos princípios da Análise do Comportamento, que podem propiciar um melhor manejo das ferramentas disponíveis para o combate da sonegação fiscal, tanto do "paradigma do crime", quanto do "paradigma do serviço". A questão acima citada, envolvendo as anistias fiscais, é apenas um exemplo da inexistência de uma avaliação mais profícua das consequências que a prática de determinada política fiscal pode acarretar no comportamento do contribuinte.

Nessa linha, Skinner (1953/2003) defende uma reavaliação das práticas governamentais, focadas quase que exclusivamente em punições. Segundo o autor, é possível utilizar bônus e subsídios como reforço positivo, induzindo o cidadão a se comportar legalmente, em vez de apenas desencorajá-lo a agir ilegalmente. 
Curioso notar, porém, que o próprio Skinner (1953/2003), ferrenho opositor do uso de punições no controle de comportamentos, cita, exemplificadamente, o procedimento de recompensar os motoristas que obedecem aos sinais de trânsito. Embora afirme que a iniciativa obteve sucesso, ressalva ser óbvio que "essa não é uma técnica adequada para todos os motoristas". Vale dizer que em alguns casos o manejo de reforços positivos pode não ser suficiente para atingir todos os cidadãos.

Sobre o uso de práticas aversivas, Baum (2006) é enfático ao dizer que aqueles que defendem que a coerção é ineficaz estão errados, na medida em que, caso treinados de forma devida, os seres humanos são bastante sensíveis às ameaças de consequências aversivas. A questão, segundo o autor, não está na eficácia imediata, mas, sim, nas consequências de longo prazo, citando especificadamente o ressentimento, o ódio e a agressão. Por isso que defende que quanto mais o comportamento for modelado por reforços positivos, mais as pessoas sentir-se-ão livres e felizes, o que não significa dizer, contudo, que as punições devem ser totalmente descartadas, mormente no contexto social atual.

Aliás, dissertando sobre questões tributárias, Kirchler (2007) alerta que, mesmo em ambientes onde há uma alta moralidade tributária, desde que apropriada, a punição pode ser necessária, já que a evasão fiscal afeta a cooperação e é vista como grande ofensa à sociedade. O autor diz que há evidências de que os indivíduos se mostram favoráveis à punição como forma de manter elevado o padrão de cooperação na sociedade.

Ocorre que, como observou Sidman (1989/2009), as agências responsáveis pela aplicação da lei somente prestam atenção no comportamento quando ele é passível de punição. $\mathrm{O}$ autor relata, ainda, que a utilização de reforçamento positivo como ferramenta de política pública é algo raro, deixando claro em sua análise o quanto isso é prejudicial à sociedade. Por outro lado, revela a realidade do mundo em que vivemos, afirmando que somente alguém ingênuo esperaria que as pessoas seguissem princípios e se comportassem honesta e eticamente sem serem obrigadas a tanto, pois vivemos em um ambiente coercitivo, 
sendo que seria surpreendente o oferecimento da "cenoura" não seguida pela aplicação do "porrete".

No entanto, há a constatação da mudança desse cenário, ainda que parcial e localizada, conforme relevam Geest e Dari-Mattiacci (2013), ao dizer que os sistemas legais tradicionalmente são baseados em punições (porrete), embora identifique uma tendência atual no emprego mais frequente de incentivos (cenoura). É o caso, por exemplo, do Programa Nota Fiscal Paulista do Governo do Estado de São Paulo, que oferece créditos e sorteios aos contribuintes.

Dentro dessa compreensão, a utilização dos reforços positivos pode ser uma alternativa eficaz no combate à sonegação fiscal (Alm et al., 1995; Falkinger \& Walther, 1991; Feld, Frey, \& Torgler, 2006). Favorece o aprendizado, aumenta a confiança, cria um clima cooperativo e impede práticas de contracontrole por parte dos contribuintes. Por outro lado, haverá situações em que a punição seria inevitável, porém a Análise do Comportamento muito pode contribuir para minimizar os efeitos colaterais do controle aversivo.

Para citar um exemplo de utilização de reforço positivo em políticas públicas, Baum (2006) relata a iniciativa de algumas comunidades em que os motoristas são gratificados, em vez de serem punidos quando transgridem as normas de trânsito. $O$ autor afirma que as pessoas sentir-se-iam diferentes caso recebessem dos agentes de trânsito recompensas por respeitarem os limites de velocidade, ainda que isso ocorresse apenas em algumas oportunidades. Arremata dizendo que esse tipo de prática pouparia verbas públicas, pois a quantidade de guardas poderia ser reduzida, seria gasto menos tempo com disputas judiciais e as pessoas ficariam mais predispostas a obedecer à lei. Essa concepção está plenamente de acordo com o "paradigma do serviço", ou seja, acarreta observância voluntária, e não forçada, demonstrando que a Análise do Comportamento e os paradigmas discutidos estão perfeitamente integrados, sendo que a ciência pode indicar os melhores caminhos para a utilização de cada uma das ferramentas que cada paradigma pressupõe. 
Vale dizer, caminhando para o encerramento deste debate, que a análise do comportamento oferece ferramentas para que o comportamento do contribuinte seja influenciado, e não apenas com a adoção de mecanismos de controle aversivo presentes no "paradigma do crime". Sidman (1989/2009) aduz com propriedade que a Análise do Comportamento "contém um corpo de princípios e dados que podem prover alguma objetividade para decidir punir ou não" (p. 20). O "paradigma do serviço" revela outras formas de aumentar a observância fiscal que não apenas através de punições, e a Análise do Comportamento tem o potencial de favorecer a busca desse objetivo.

É como Sidman (1989/2009) bem relatou ao afirmar que "uma análise comportamental não pode, em si mesma, tomar as decisões necessárias, mas pode mostrar quais as consequências prováveis de qualquer decisão" (p. 163).

Ambas as bases teóricas abordadas no presente estudo, portanto, em tese poderiam ser integradas, não apenas para possibilitar um arsenal mais amplo de ferramentas disponíveis para o combate à evasão fiscal, mas também para propiciar um entendimento mais abrangente e um manejo mais adequado dessas alternativas.

O sucesso dessa iniciativa depende de uma correta compreensão do que está envolvido no comportamento de pagar tributo. Efetivamente, o contribuinte tem duas alternativas: pagar ou não pagar seus tributos. Ao pagar, o indivíduo está sendo punido, já que é retirado do ambiente algo que lhe é extremamente reforçador, no caso o dinheiro. Em condições normais, porém, ele receberá reforços positivos, através da oferta de serviços públicos. Não ocorrendo essa conseqüência, o comportamento do contribuinte não será reforçado. Suponha-se agora que essa consequência venha a se verificar. Ainda assim, estaremos diante de um reforço de longo prazo, ao passo que ao não pagar seus tributos o indivíduo está diante de um reforço de curto prazo (manutenção do seu dinheiro), o que Ihe deixa inclinado a escolher essa opção, haja 
vista que o reforço é mais garantido e imediato. Baum (2006), exemplificando com o comportamento de um fumante, trata esse dilema como armadilha de reforço.

Por isso que, para melhor convencimento do contribuinte, há necessidade de substituição do reforço imediato (dinheiro) por outros, como aprovação social, recompensas, tratamento adequado por parte das autoridades, dentre outros que minimizem o efeito da perda do reforçador imediato, conforme analogamente parece defender Baum (2006).

Feld e Frey (2007), inclusive, citam exemplos específicos de recompensas, como entradas gratuitas em museus, exibições e outras atividades culturais, ou o oferecimento de $50 \%$ de desconto em transporte público. A punição também é utilizada para contrabalancear esse dilema do indivíduo: é possível que ao não pagar o tributo o contribuinte arque com um custo ainda maior, ou seja, o reforçador (dinheiro) seja perdido no futuro com um adicional.

Há que se destacar, contudo, que o oferecimento de recompensas, em especial materiais, como é o caso de dinheiro, pode ter consequências negativas indiretas, conforme alertam Feld e Frey (2007), afirmando que elas criam a expectativa de que recompensas futuras serão fornecidas, de tal forma que o comportamento desejado somente é posto em prática se as recompensas estiverem presentes, o que pode criar um sério problema de alocação de recursos. É por isso que o estudo de Smith e Stalans (1991) é primoroso, na medida em que sustenta que incentivos verbais também podem representar uma motivação que favoreça a observância de normas, inclusive tributárias.

Dada essa complexidade, não é ocioso ressaltar ser imprescindível que o tema seja entendido em sentido amplo, envolvendo todos os princípios da Análise do Comportamento. A partir dessa compreensão e da integração dos paradigmas "do crime" e "do serviço", é possível que os níveis de observância fiscal sejam afetados positivamente, inserindo nesse contexto a utilização de práticas não aversivas, como, por exemplo, o oferecimento de recompensa aos 
100

contribuintes, inclusive verbais, embora não se possa descartar o emprego de punições, sempre levando-se em conta seus efeitos colaterais. 


\section{PROCEDIMENTOS METODOLÓGICOS}

A proposta metodológica desta dissertação fundamenta-se, inicialmente, no levantamento de dados primários (documentação direta) e secundários (documentação indireta), através da realização de questionário on-line e experimento, bem como análise de documentos, livros, artigos científicos, periódicos, dentre outras fontes citadas no decorrer do estudo.

No que tange à documentação indireta, fez-se uso de ampla quantidade de artigos científicos que abordam, ainda que parcialmente, o tema objeto desta dissertação, desde a publicação dos seminais artigos de Allingham e Sandmo (1972) e Srinivasan (1973), até estudos recém-publicados e que demonstram o Estado da Arte da pesquisa sobre observância fiscal. Por se tratar de tema pouco explorado no Brasil, a literatura consultada compreendeu, em sua essência, pesquisas realizadas em outros países.

Além disso, o estudo contemplou pesquisa envolvendo a Análise do Comportamento, porém, nesse caso, por se tratar de teoria bastante consolidada, optou-se pelo foco na obra do próprio Skinner, sem, contudo, sonegar a consulta a outras fontes.

No tocante à coleta de dados, o estudo foi dividido em duas etapas, na pretensão de responder as questões de pesquisas e testar suas respectivas hipóteses. Na primeira etapa foi empregado um questionário on-line com comparação de cenários, e, na segunda, optou-se pelo método experimental.

\subsection{Da coleta de dados empíricos}

A coleta de dados foi dividida em duas etapas, sendo a primeira através da aplicação de um questionário, ou seja, uma pesquisa on-line realizada por meio da internet, e a segunda por meio da aplicação de um experimento em condições laboratoriais. Em ambos os casos foi 
utilizado software especialmente desenvolvido para os objetivos da pesquisa, o qual será detalhado adiante. Algumas "fotografias" contidas nos Apêndices A e B ilustram referido software. Os Apêndices C e D trazem a descrição detalhada de cada cenário da pesquisa e do experimento.

Em ambas as etapas utilizou-se como base o modelo criado por Kirchler (2007), denominado Slippery Slope Framework, que se baseia em um clima de interação dos cidadãos de determinado país com as autoridades locais. Essa interação tem como "mola mestra" a confiança dos indivíduos no Governo e a percepção do poder exercido pelas autoridades, representado pela capacidade de coerção e controle do comportamento dos contribuintes em relação ao cumprimento de suas obrigações tributárias. Essa interação acaba por influenciar os níveis de observância fiscal, voluntária e forçada.

Na primeira etapa foi replicada parte do estudo realizado por Wahl, Kastlunger e Kirchler (2010), com redução da quantidade de períodos de pagamento de impostos, de vinte para dez, e, por óbvio, adaptação ao vernáculo. Essa fase teve por objetivo avaliar de que modo a interação entre contribuintes, autoridades fiscais e Governo afeta o comportamento dos primeiros, respondendo, assim, a primeira questão de pesquisa, proposta no tópico 1.4, e testando suas respectivas hipóteses $\left(\mathrm{H}_{1}\right.$ e $\left.\mathrm{H}_{2}\right)$, conforme consta do tópico 1.5 deste estudo.

Pelo fato de coleta de dados ter sido realizada através de pesquisa on-line, sem manipulação de variáveis e sem adoção de técnicas de controle, com exceção da randomização dos participantes, optou-se por não caracterizá-la como método experimental. Preferiu-se denominá-la, meramente, de questionário, aplicada eletronicamente, a fim de se poder comparar diferentes cenários simulados, captando a reação dos participantes de acordo com as características específicas de cada grupo.

Na segunda etapa optou-se pela realização de experimento controlado em condições laboratoriais. Alm e Torgler (2011) reconhecem a dificuldade de realização de pesquisas sobre 
evasão fiscal, dada a inexistência ou existência incompleta, ou mesmo enviesada, de dados. Citam que a utilização de experimento ajuda a melhor testar hipóteses e simular situações reais de evasão fiscal, o que justifica o método escolhido. Essa fase teve por objetivo avaliar quais as principais consequências da implementação de políticas públicas baseadas em punições e recompensas na busca por mais observância fiscal, respondendo, assim, a segunda questão de pesquisa, proposta no tópico 1.4 , e testando sua respectiva hipótese $\left(\mathrm{H}_{3}\right)$, conforme consta do tópico 1.5 deste estudo.

Conveniente observar que se procurou realizar uma replicação praticamente exata e outra conceitual do modelo Slippery Slope Framework. Sobre isso, Cozby (2003) avalia que as replicações conceituais têm o potencial de ser mais relevantes, já que colaboram para aumento de nosso conhecimento em temas relacionados ao comportamento humano. Portanto, ao se propor uma replicação conceitual através do experimento, busca-se não apenas responder a questão de pesquisa, mas, também, através dela, aumentar o conhecimento sobre o fenômeno sonegação fiscal.

\subsection{Slippery Slope Framework}

O modelo concebido por Kirchler (2007) e operacionalizado em pesquisa conduzida por Wahl et al. (2010) integram a perspectiva econômica e a psicológica em um único framework (Alm et al., 2012a). O modelo reconhece a existência de uma inter-relação de autoridades com contribuintes. A forma como se dá essa interação afeta o nível de observância fiscal, seja através da cooperação entre esses atores ou em razão do exercício do poder por parte das autoridades (Kirchler, 2007).

Dessa forma, o foco do Slippery Slope Framework não é unicamente a coerção em busca de observância, mas, igualmente, moldar a interação dos atores sociais visando promover confiança mútua e cooperação (Alm et al., 2012b). O instrumento possibilita a avaliação da interação desses atores sociais, não focando apenas na suposta racionalidade econômica do 
contribuinte, mas considerando, igualmente, a relação de poder legal imposta pelas autoridades no sentido de enforcement da lei, bem como a confiança dos cidadãos no Governo. Pressupõe, portanto, a existência de uma interação que promove a confiança dos contribuintes ou a percepção do poder das autoridades, o que afeta os níveis de observância voluntária e forçada, respectivamente (Kirchler et al., 2014).

Kirchler (2007) sustenta que os contribuintes reagem de acordo com a abordagem utilizada pelas autoridades fiscais, de modo que um eventual clima de "caça entre polícia e ladrão" deteriora a possibilidade de cooperação voluntária dos pagadores de tributos. Por outro lado, quando há confiança nas autoridades fiscais e o sistema tributário é caracterizado pelo respeito aos contribuintes, transparência dos procedimentos e justiça fiscal, há mais aderência a uma cooperação voluntária da sociedade, reduzindo a sonegação fiscal.

Vale dizer que, em um ambiente onde os cidadãos não confiam no Governo e a relação entre autoridades fiscais e contribuintes é conflituosa e não cooperativa, a consequência será a inexistência ou o reduzido nível de observância voluntária. Nesse contexto, fiscalizações e aplicação de multas aumentam a observância fiscal forçada, porém não criam, no longo prazo, um ambiente de voluntariedade por parte dos contribuintes.

Alm et al. (2012b) produz lição semelhante, ao afirmar que a observância voluntária depende basicamente da confiança dos cidadãos no Governo, especialmente considerando-se a percepção daqueles em relação a justiça e norma social. Braithwaite (2011) complementa essa ideia afirmando que o maior desafio das autoridades é o efeito que a desilusão com o Governo causa nos cidadãos, no sentido de reduzir a cooperação com o sistema tributário. De outro lado, caso o contribuinte não coopere voluntariamente, ainda restará o poder das autoridades influenciando a observância forçada, dependendo de sua capacidade de exercer coerção no sentido de impor a lei. 
O modelo pressupõe, portanto, que o nível de observância fiscal resultará da interação de confiança e poder, o que acarretará observância voluntária ou forçada, como sugere o Gráfico 1.

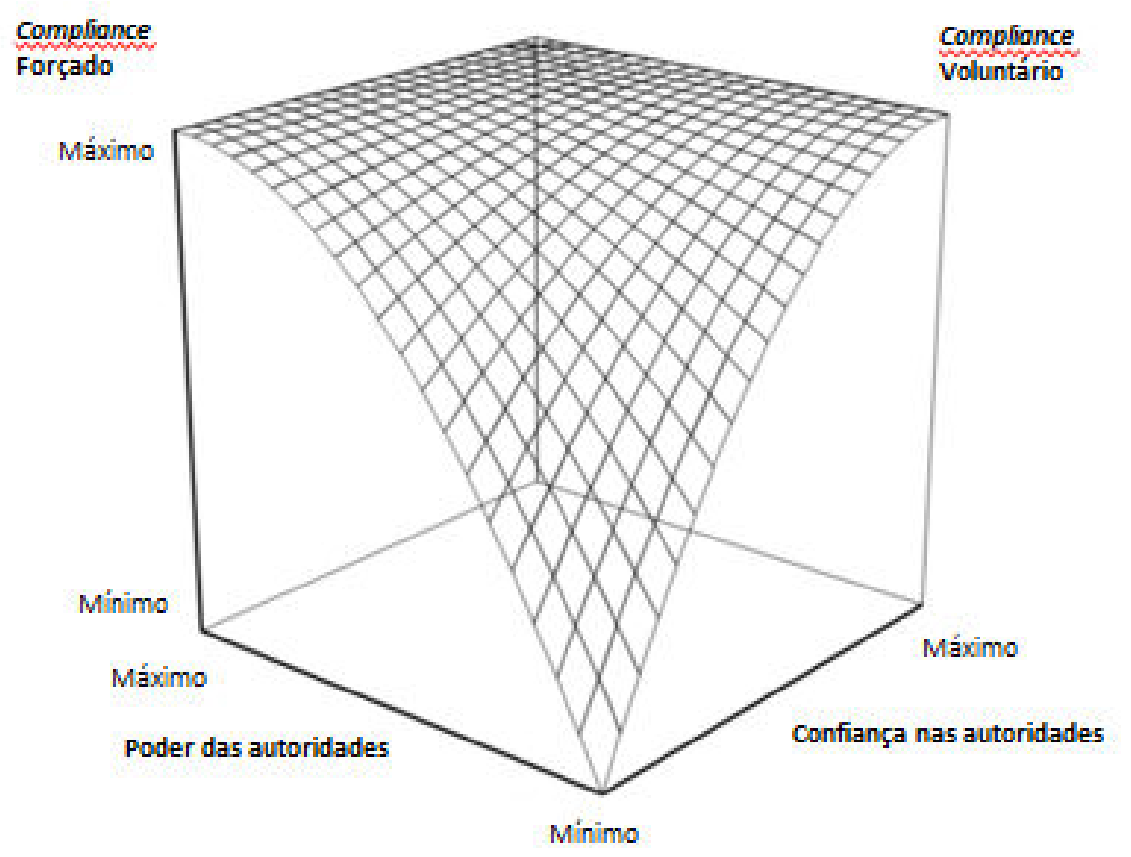

Gráfico 1 - Slippery Slope Framework do comportamento de observância fiscal Fonte: Kirchler (2007).

Kirchler (2007) sintetiza explicando que o Slippery Slope Framework se baseia em dois tipos de abordagem. O primeiro deles, por sua vez, baseia-se no "paradigma do crime", em que é assumido um clima de desconfiança e falta de cooperação entre autoridades e contribuintes, sendo a observância resultado do poder daquelas em impingir o pagamento forçado por partes dos últimos. O segundo se lastreia no "paradigma do serviço", em que o cliente é tratado pelas autoridades como uma espécie de cliente da administração pública, beneficiando-se dos serviços que the são ofertados em razão de sua contribuição para o sistema. Nesse caso, pressupõe-se a existência de um clima de cooperação e interação respeitosa de autoridades e 
contribuintes, favorecendo a confiança. Como conseqüência, a observância fiscal resulta da cooperação voluntária dos contribuintes.

Kastlunger et al. (2013) complementam essa explanação articulando que o framework demonstra haver duas abordagens que prometem alto nível de observância fiscal, seja através do exercício do poder ou em razão da confiança. Ressalvam, contudo, que a qualidade da observância difere. Poder tem como resultado observância forçada e confiança observância voluntária. Segundo os autores, esta última é desejada, pois não torna os contribuintes opositores das autoridades e evita custos de controle.

O Slippery Slope Framework, embora recente, já foi testado empiricamente por alguns pesquisadores, sendo inédita sua aplicação no Brasil. Wahl et al. (2010), por meio de estudo experimental e pesquisa on-line, demonstraram empiricamente a validade do modelo. $O$ estudo avaliou diferentes cenários, considerando alta e baixa confiança e poder como variáveis explicativas, bem como a influência no nível de observância fiscal, ou seja, a variável dependente ou efeito. Os resultados comprovam que o nível de observância fiscal é mais alto em ambientes onde a confiança e o poder das autoridades são significativos. Do mesmo modo, demonstram que o nível de observância voluntária é maior em ambientes de alta confiança, sendo evidenciado que a observância forçada tem mais influência quando a confiança é baixa e o poder é alto.

Benk e Budak (2012) testaram o modelo na Turquia, e constataram que a confiança nas autoridades proporciona observância fiscal voluntária. Além disso, ao contrário do que os autores hipotetizaram, a percepção de poder das autoridades também influencia a observância voluntária. Por outro lado, verificou-se que essa percepção contribui para a observância fiscal forçada, o que não ocorre com o nível de confiança, confirmando o framework.

Lozza, Kastlunger, Tagliabue e Kirchler (2013) conduziram estudo comparativo na Itália, com indivíduos com preferências políticas de esquerda e de direita, e confirmaram, como 
propõe o modelo, a existência de dois diferentes caminhos que influenciam o cumprimento das obrigações fiscais: confiança e poder.

Kastlunger et al. (2013) também testaram o modelo na Itália, através de pesquisa online com 389 profissionais autônomos, empregando o método de equações estruturais. Os resultados confirmam os pressupostos do Slippery Slope Framework no sentido de que a confiança produz o cumprimento voluntário das obrigações fiscais, enquanto o poder gera o cumprimento forçado. Os autores foram adiante, e verificaram que confiança e poder são positivamente relacionados com poder considerado legítimo. O poder legítimo, assumem os autores, depende da relação entre confiança e poder. Esclarecem que caso confiem nas autoridades, os cidadãos as veem como fortes e poderosas, exercendo um poder legítimo. Em caso contrário, os cidadãos percebem a mesma força como um poder meramente coercitivo.

Müehlbacher et al. (2011) realizaram pesquisa através de questionário on-line com indivíduos residentes na Áustria, Reino Unido e República Tcheca, cujos resultados confirmam que a confiança nas autoridades fiscais afeta fortemente o cumprimento voluntário das obrigações tributárias, ao passo que o poder atribuído às autoridades tem como consequência o aumento do cumprimento forçado das obrigações fiscais. Adicionalmente, os dados revelam que o cumprimento forçado é negativamente relacionado à confiança, sugerindo que aquela variável induz cumprimento fiscal voluntário, reduzindo a sensação de que a pessoa é forçada a pagar impostos.

Lemoine e Roland-Lévy (2012) testaram o modelo com contribuintes franceses, e concluíram que os resultados estão totalmente alinhados com os pressupostos do Slippery Slope Framework no sentido de que confiança e força influenciam duas diferentes formas de observância: voluntária e forçada, respectivamente.

Gangl et al. (2013) também realizaram estudo empírico do modelo (survey), dessa feita com contribuintes holandeses, e constataram que o "paradigma do serviço" facilita a 
observância fiscal e é um meio eficiente de aumentar a confiança dos indivíduos, resultado que se alinha com os pressupostos do Slippery Slope Framework. O estudo verificou, ainda, que as mulheres, os contribuintes mais velhos e uma maior percepção da probabilidade de auditorias e punições também influenciam positivamente a observância tributária.

Kogler et al. (2013) propuseram-se a testar as premissas do framework em quatro países europeus que se distinguem em termos culturais e econômicos. Os resultados confirmam a influência da confiança e do poder como determinantes da observância fiscal, sendo que os participantes da pesquisa alocados ao grupo em que a confiança era alta demonstraram mais observância voluntária, ao passo que aqueles do grupo de alta força demonstraram mais observância forçada. Interessante notar que os resultados ainda demonstram que os participantes russos apresentaram um nível mais baixo de cumprimento voluntário do que os demais participantes. Segundo os autores, isso pode ser consequência de um mais baixo nível de confiança dos russos em suas autoridades, confirmado pelo fato de o país encontrar-se mal colocado na lista de Transparência Internacional, em comparação com os demais pesquisados.

Lisi (2012a) optou por testar o framework utilizando a técnica de regressão, divergindo dos métodos até então adotados pelos pesquisadores, inclusive neste estudo. Não obstante, os resultados confirmaram a validade do Slippery Slope Framework no sentido de que um aumento na confiança e no poder resulta em uma redução dos níveis de inadimplência fiscal. Os resultados demonstram, ainda, que a confiança produz um efeito mais significativo do que o poder, o que é indício da validade do "paradigma do serviço".

Lisi (2012b) propôs-se a estudar o modelo verificando a relação entre observância fiscal, evasão fiscal e taxa de desemprego. Os resultados demonstram que através da utilização de uma mescla de instrumentos de dissuasão, a confiança nas autoridades é maximizada, afetando positivamente a observância voluntária e, como consequência, reduzindo a evasão fiscal, o que, segundo o autor, pode propiciar uma redução da taxa de desemprego. 
Em síntese, o modelo proposto, embora recente, já foi objeto de algumas avaliações empíricas, e leva em conta esse clima interativo, segundo o qual o comportamento dos contribuintes depende do nível de confiança no Governo e da percepção do poder das autoridades por parte dos contribuintes, sendo que essas variáveis afetam os dois tipos de observância fiscal: a voluntária e a forçada. Quando confiança e poder se apresentam em um nível reduzido, assume-se que o pagamento de tributos será igualmente reduzido, com os contribuintes agindo de forma egoística e buscando maximizar sua utilidade. Diametralmente oposto, sendo elevados os níveis de confiança e poder, o nível de observância fiscal será elevado (Alm et al.; 2012b).

Desse modo, a pesquisa terá como base, em ambas as fases, o modelo acima descrito, com algumas modificações e efetiva intervenção no sistema na segunda fase, conforme explicitado adiante.

\subsubsection{Da pesquisa on-line}

A primeira fase de coleta de dados objetiva responder a primeira questão de pesquisa, ou seja: De que modo a interação entre contribuintes, autoridades fiscais e Governo afeta o comportamento dos primeiros? Pretendeu-se avaliar se essa interação, que pode gerar um clima de confiança no Governo e a percepção, por parte dos contribuintes, do poder das autoridades, influencia o comportamento voluntário e forçado.

Em termos formais, procura-se testar as hipóteses metodológicas $H_{1}$, de que a alta confiança dos contribuintes no Governo tem como resultado mais observância fiscal voluntária; e $\mathrm{H}_{2}$, de que a alta percepção do poder das autoridades fiscais, por parte dos contribuintes, tem como resultado mais observância fiscal forçada. Para tanto, confiança e poder foram empregados como variáveis independentes e observância voluntária e observância forçada como variáveis dependentes. O Apêndice $C$ explicita todas as etapas e o detalhamento da pesquisa. 
A pesquisa foi respondida por meio da internet, sendo os participantes capturados através da metodologia snowball sampling, ou seja, o link foi divulgado em redes sociais e através de e-mails, criando-se uma corrente de exposição e captação de sujeitos.

Ao acessar o link do website em que o software da pesquisa estava hospedado, os participantes recebiam instruções iniciais e, então, eram distribuídos randomicamente em quatro diferentes tipos de país simulado, considerando as variáveis de alta ou baixa confiança no Governo e alto e baixo poder das autoridades. Após cientificar-se das instruções, cada participante era convidado a ler a descrição do país e, tanto quanto possível, imaginar-se nele vivendo e recolhendo seus tributos. Adotou-se o cuidado de alertar que no país em referência não havia retenção de tributos na fonte, ou seja, a decisão de recolhimento fiscal competia exclusivamente ao participante.

Logo após a apresentação das características, o participante era instado a responder duas perguntas para avaliar seu entendimento e leitura no que se referia ao contexto e características do seu país fictício. Assim, as perguntas, com alternativas em escala likert, questionavam se naquele país havia alta confiança no Governo e alto poder das autoridades. Respostas divergentes, que sugeriam a falta de leitura ou entendimento equivocado das características do país acarretaram o descarte do participante. Para ilustrar: se o país do participante tivesse como característica alta confiança dos contribuintes no Governo e alto poder de imposição por parte das autoridades, respostas das questões em sentido contrário ocasionariam o descarte dos dados.

Esse procedimento objetivou reduzir a possibilidade de participação sem a atenção necessária, que poderia de alguma forma desvirtuar os resultados.

Preenchidos esses requisitos, era solicitado ao participante que respondesse questões com alternativas em escala likert, para avaliar os níveis de observância voluntária e observância 
forçada, considerando as características do país simulado, tal qual se deu na pesquisa conduzida por Wahl et al. (2010). Superada essa etapa, competia a cada participante declarar o valor de imposto de renda a pagar durante dez períodos consecutivos, sendo, ao final, dispensado.

Reitera-se que, como nessa primeira etapa não houve manipulação de variáveis dentro de cada grupo, optou-se por não se caracterizar o método empregado como um experimento, o que justifica sua nomeação tão-somente como questionário, não obstante os resultados servirem para comparação de diferentes cenários.

\subsubsection{Do experimento laboratorial}

Essa etapa da pesquisa objetivou responder a segunda questão de pesquisa: Quais as principais consequências da implementação de políticas públicas baseadas em punições e recompensas, na busca por mais observância fiscal? Dessa forma, pretendeu-se avaliar, com base nos ensinamentos da Análise do Comportamento, se é possível influenciar o aprendizado e comportamento dos contribuintes brasileiros através do manejo de punições e recompensas efetivas e potenciais, em busca de mais conformidade.

O escopo, por conseguinte, consiste em testar a hipótese $\mathrm{H}_{3}$, de que a implementação de políticas públicas baseadas em punições e recompensas gera mais conformidade fiscal. Nessa etapa, as recompensas ou regras prevendo-as em caso de conformidade fiscal e punições foram empregadas como variável independente, procurando avaliar os seus efeitos na variável dependente nível de observância fiscal. Nesse passo, foca-se na variável crítica consequência punição ou recompensa (inclusive regra prevendo-a), que permitirá avaliar como utilizá-la em favor da conformidade tributária. O Apêndice $D$ traz todas as etapas e o detalhamento do experimento. 
Para tanto, a coleta de dados deu-se por meio de experimento, método descrito como o modelo ótimo de avaliação científica (Campbell \& Stanley, 1973), por permitir a análise direta de relações de causa e efeito entre variáveis. Sobre o tema, Shadish, Cook, \& Campbell (2002) assinalam que a utilização de experimentos representou um grande avanço no modo pelo qual o ser humano adquire conhecimento. Citam os autores que antes do século XVII os filósofos usavam a observação apenas para suportar suas teorias, embora entendessem que o método era subordinado ao que eles denominavam "princípios básicos", sustentando que os homens conhecem a verdade por sua própria natureza ou por revelação divina, independentemente da observação.

Nesse sentido, os autores relatam que no século XVII deu-se início ao uso da observação para corrigir supostos equívocos da teoria ou do conhecimento religioso. O movimento - que pode ser visto como uma revolução na forma de adquirir conhecimento - causou diversos incidentes, especialmente em razão da negação dos religiosos em aceitar as novas teorias daí advindas, como, por exemplo, o caso notório de Galileu Galilei e sua defesa da teoria do heliocentrismo.

É nesse contexto de revolução científica que surgem os estudos experimentais. Todavia, inicialmente tais estudos limitavam-se à observação passiva dos acontecimentos naturais. Segundo Shadish et al. (2002), com o passar dos tempos, contudo, os pesquisadores adotam uma postura ativa, tomando ações a fim de alterar deliberadamente o ambiente e, então, verificar o resultado. A ciência experimental surgiu justamente para observar os efeitos dessas manipulações (Shadish et al., 2002).

Dessa forma, o método experimental se caracteriza por ser um teste ou uma observação realizada em um ambiente controlado, onde o pesquisador pratica algumas intervenções com o intuito de avaliar seus efeitos, analisando a relação entre a variável dependente e a variável independente (Campbell \& Stanley, 1973; Cook \& Campbell, 1979). Shadish et al. (2002) citam Yaremko, Harari, Harrison e Lynn (1986), que opinaram que um 
experimento se caracteriza como uma ou mais variáveis independentes que são manipuladas para que seus efeitos sejam observados em uma ou mais variáveis dependentes. Libby, Bloomfield e Nelson (2002) apresentam entendimento semelhante, citando a possibilidade de mensuração do processo de intervenção de variáveis através de procedimentos randômicos.

Na mesma esteira, Bryant, Hunton e Stone (2004) definem experimento como uma pesquisa que manipula de forma sistemática uma ou mais variáveis, realiza o controle de variáveis externas e observa empiricamente os efeitos resultantes do estímulo, conceito análogo ao proposto por Martins e Theóphilo (2009). O próprio Skinner (1974/2006) destaca que o cenário laboratorial é planejado no sentido de as condições serem controladas, sendo algumas mantidas e outras modificadas, comparando-se o efeito dessas manipulações, o que possibilita a aferição da relação entre a variável independente e a dependente, tornando plausível avaliar as variáveis críticas do estudo. Em síntese, como o autor afirmou em outra oportunidade (Skinner, 1953/2003), "a característica mais importante do método laboratorial é a manipulação deliberada de variáveis" (p. 40).

É o que se pretende nessa etapa, ou seja, conduzir um estudo controlado com distribuição randômica, que se caracteriza como uma pesquisa em que são avaliados os efeitos de uma ou mais intervenções, comparando-se grupos divididos aleatoriamente em subgrupos experimentais e de controle (Schwarz, Flamant, \& Lellouch, 1980; Sprinkle, 2003).

Destaque-se que o tema em estudo nesta dissertação é especialmente propício de realização através de experimentos. Segundo Alm e Torgler (2011), as dificuldades de obtenção de dados confiáveis sobre o tema e a complexidade das teorias que compreendam todos os fatores que influenciam o comportamento do contribuinte indicam o experimento como uma maneira efetiva de simplificação da análise a fim de fornecer resultados analíticos claros, evitando-se a ambiguidade dos resultados. Concluem que, embora os experimentos também apresentem fragilidades, em comparação com outras metodologias seu uso é fortemente indicado, ao menos no que diz respeito ao assunto aqui estudado, opinião semelhante à de 
Spicer e Becker (1980) e Spicer e Thomas (1982), que igualmente defendem a utilização desse método de pesquisa, ressalvando que a artificialidade presente nos estudos experimentais dificulta a generalização de resultados, sem, no entanto, invalidá-los.

Adicionalmente, as razões para se optar por esse método são encontradas na própria obra de Skinner (1974/2006), ao revelar que o sentimento e o comportamento de um indivíduo em relação a determinado estímulo diferem de seu relato verbal. Vale dizer que a adoção de outros métodos de pesquisa, como a survey ou entrevista com os contribuintes, poderia produzir dados enviesados, justamente devido a essa dissonância entre o sentimento sobre o estímulo e o seu relato. Através do experimento, é montado um cenário fictício simulando a realidade, em que o participante tem que tomar decisões de acordo com o estímulo, minimizando distorções que ocorreriam no relato verbal desse sentimento. Em suma, o experimento é mais adequado quando se pretende captar o efeito da manipulação do ambiente.

Lipsey e Hurley (2009) descrevem as etapas básicas da realização de um experimento, a saber: seleção dos participantes e sua distribuição, preferencialmente de maneira aleatória, em grupos de tratamento e de controle; intervenção de variáveis no grupo de tratamento, e não no grupo de controle; monitoramento do experimento para assegurar a inexistência de diferenças entre o grupo de tratamento e o grupo controle, exceto pela intervenção praticada pelo pesquisador; mensuração dos resultados; e análise estatística para determinar se os grupos diferem no que tange às variáveis dependentes.

Na mesma linha, Andery (2010) cita os procedimentos-padrão do método experimental consagrados pelas ciências comportamentais: "a amostragem e a participação de grande número de sujeitos; sua distribuição em dois grupos, chamados de grupo experimental e o grupo controle; a atribuição randômica dos sujeitos nos grupos; e o tratamento estatístico dos resultados" (p. 325). 
Em tempo dizer que há uma tênue diferença entre experimento e quase-experimento. A principal diferença é que neste último inexiste uma distribuição aleatória de participantes, o que impossibilita o controle de variáveis explicativas diversas. Segundo Garson (2001), em experimentos o controle é atingido através da randomização dos participantes em grupos de tratamento e controle. O autor é enfático ao afirmar que em razão da randomização o pesquisador pode assumir que todos os fatores não mensurados no experimento foram neutralizados.

É certo que podem surgir críticas, haja vista que o estudo foi realizado com a aplicação do experimento em uma amostra escolhida por conveniência (estudantes de pós-graduação ou em segunda graduação). Todavia, foi procedida a distribuição randômica de participantes, o que mantém a característica do método experimental, sendo prejudicada, porém, a inferência dos resultados, devido à inexistência de confirmação de que a amostra escolhida tem as mesmas características da população nacional, por exemplo. Isso não retira o mérito do estudo, como sustentam Shadish et al. (2002), ao dizer que os experimentos que demonstram generalização limitada podem ser tão válidos quanto aqueles que demonstram ampla generalização.

De qualquer forma, levando-se em conta que entre as alternativas estudadas (assim considerados três diferentes grupos conforme apresentado adiante), a distribuição foi randomizada (automaticamente, pelo programa computacional), o estudo não perdeu a característica de experimento, embora ainda que fosse caracterizado como um quaseexperimento, não haveria invalidação de seus resultados, o que torna a discussão despicienda na conjuntura do estudo.

Reforce-se que o experimento se valeu do modelo criado por Kirchler (2007), empregado na pesquisa empírica de Wahl et al. (2010), denominado Slippery Slope Framework. Todavia, não foram avaliados quatro diferentes tipos de cenário em relação às características de confiança e poder, optando-se por pesquisar tão-somente um país fictício em que a 
população tem pouca confiança no Governo e as autoridades têm pouco poder de enforcement. Tal opção parte do pressuposto de que em países com essas características o aprendizado do contribuinte é mais necessário e efetivo para fins de conformidade, além de facilitar a avaliação do efeito da intervenção realizada no cenário experimental.

Desse modo, foi introduzida em um contexto experimental três grupos distintos. No primeiro grupo, foram simuladas recompensas efetivas e potenciais, inclusive através de regras prevendo esta possibilidade, enquanto no segundo grupo foram simuladas auditorias e punições dos contribuintes sonegadores. Por fim, os resultados foram confrontados com aqueles apresentados pelo grupo controle, em que não foi feita nenhuma intervenção no ambiente.

O experimento foi aplicado em sala de aula, com a presença física do pesquisador, através de acesso via internet. Inicialmente foi feita breve explanação acerca do estudo e do experimento, além de ser colhido termo de compromisso, aceite e confidencialidade dos participantes, adotando-se os cuidados para não se antecipar detalhes que pudessem influenciar as respostas.

Destaque-se que embora a internet tenha sido utilizada para facilitar a realização do experimento, possibilitando que cada participante o acessasse de seu próprio computador, foram realizadas sessões com a presença do pesquisador, momentos em que foi colhido o consentimento informado e distribuídas senhas individuais, não havendo significativa diferença do experimento de laboratório, na medida em que reproduzidas suas condições, sendo a internet apenas o veículo para a coleta dos dados. Ressalte-se que Andery (2010) indica que o laboratório é apenas um setting em que as são construídas as condições necessárias para o estudo, possibilitando mais controle de variáveis, o que foi reproduzido durante a coleta dos dados. 
De qualquer modo, Bryant et al. (2004) aludem que o pesquisador deve adotar algumas cautelas na realização de um experimento através da internet, dentre as quais destacam a questão já abordada da distribuição aleatória dos participantes. Mencionam, ainda, que em experimentos computacionais é necessário garantir que o participante não irá alterar as respostas anteriores em razão de estímulos recebidos durante o experimento. Por fim, afirmam que o sujeito deve consentir sobre sua participação na pesquisa, sendo informado sobre a existência de riscos e eventual recompensa. Todas essas cautelas foram adotadas, mitigando-se possíveis vieses na coleta dos dados via internet. Como anteriormente mencionado, a internet funcionou apenas como veículo, não havendo acesso livre aos participantes, que somente acessavam o experimento após consentirem e receberem senha individual.

Consequentemente, a realização do experimento foi controlada, condicionando-se a participação de cada um à assinatura do consentimento informado e ao recebimento da senha. O pesquisador, por sua vez, permaneceu durante toda a sessão acompanhando o desenvolvimento da pesquisa, sendo correto, portanto, definir o experimento como laboratorial.

Reitere-se, de qualquer modo, que Bryant et al. (2004) citam que as pesquisas demonstram evidências empíricas que não encontraram diferenças entre experimentos realizados em laboratório e através da internet, embora reconheçam algumas fragilidades em experimentos realizados pela internet, como, por exemplo, o preenchimento da pesquisa de modo distraído, como assistindo televisão ou durante a madrugada, bem como a possibilidade de um mesmo sujeito participar da pesquisa mais de uma vez, o que não é o caso do experimento aqui conduzido, em que todas essas possibilidades foram controladas.

Em relação à seleção dos participantes, foi construída uma amostra por conveniência, constituída de alunos de MBA ou que vinham cursando uma segunda graduação. Optou-se pela não utilização de estudantes em primeira graduação, por se entender que, em sua maioria, não detêm experiência significativa em questões relativas ao recolhimento de tributos, sendo que 
muitos deles nem sequer ultrapassaram o teto de rendimentos que os obrigaria a pagar imposto de renda.

Ademais, é fundamental ressaltar que a pesquisa envolve questões comportamentais e que os estudantes de nível de graduação têm perfil mais jovem e em desenvolvimento. Nesse sentido, Cozby (2003) destaca que esses jovens ainda se encontram em uma fase em que o sentido de identidade ainda está em desenvolvimento, havendo grande necessidade de aprovação por seus pares, fatores que podem enviesar o resultado.

Embora se idealize a utilização de amostras probabilísticas, a prática acadêmica, mormente aquela voltada para o estudo do comportamento, demonstra uma realidade diversa. Em primeiro lugar, é tarefa hercúlea reunir indivíduos dispostos a participar de experimentos dessa magnitude, especialmente porque exige certa concentração e dedicação durante razoável período de tempo (o experimento durava cerca de 30 minutos), justificando-se o perfil definido para a amostra, o que é perfeitamente aceitável para os fins deste estudo.

Isso, contudo, não afeta a validade dos resultados, embora comprometa sua inferência. Não obstante, Cozby (2003) relata ser comum em pesquisas comportamentais a utilização de sujeitos da forma mais conveniente possível, a fim de não inviabilizar o estudo, argumentando ainda que há evidências empíricas de que os resultados daí gerados podem ser generalizados.

Realmente, há que se considerar questões relativas à viabilidade da pesquisa. Dada a complexidade do experimento proposto, uma amostra totalmente aleatória inviabilizaria o desenvolvimento do estudo, o que significaria desperdiçar a oportunidade de compreender melhor o tema pesquisado.

Dissertando sobre o assunto, Libby et al. (2002) recomendam que o pesquisador não deve buscar a participação de sujeitos mais sofisticados que o necessário para os objetivos da pesquisa. No caso em estudo, é suficientemente seguro assumir que estudantes de MBA e 
alunos de segunda graduação são sujeitos adequados para participar de experimento que avalia o comportamento do contribuinte, já que, em certa medida, todos estão sujeitos à interação com autoridades fiscais e com o Governo.

Considerou-se desnecessário o oferecimento de incentivo financeiro. Libby et al. (2002) são categóricos em dizer que há poucas evidências de que tais incentivos eliminem quaisquer vieses dos participantes. Alm e Torgler (2011) afirmam, porém, que a maioria dos estudos experimentais no campo fiscal prevê um incentivo econômico, variando de acordo com as decisões do participante. Contudo, identificaram-se, dentre outros, dois possíveis pontos negativos em relação ao incentivo financeiro. O primeiro se refere ao fato de que em uma das condições experimentais, o chamado grupo recompensas, não havia simulação de auditorias e punições, justamente porque o objetivo do estudo é a avaliação de políticas públicas envolvendo puinições e recompensas efetivas e potenciais. Assim, o participante desse grupo, no decorrer do experimento, mediante ausência de auditorias e punições, poderia ter a percepção de que a manipulação das variáveis não envolvia qualquer risco, de modo que, caso optasse pela sonegação fiscal, seu benefício financeiro seria otimizado, o que enviesaria o resultado.

Adicionalmente, caso o incentivo financeiro fosse reduzido, o participante tenderia a adotar um comportamento mais agressivo, como se estivesse em um jogo, na medida em que seu risco seria, igualmente, pequeno (Kirchler, 2007). Isso obrigaria a condução do experimento com valores significativos, o que inviabilizaria a realização do estudo, além de ensejar a arguição de questões de ordem ética, especialmente levando-se em conta que no Brasil, ao contrário do que ocorre no Exterior, a realização de pesquisas com incentivo financeiro ainda é incipiente. Por fim, estudo conduzido por Boylan e Sprinkle (2001) demonstra que há diferença no comportamento do participante de experimentos que recebe incentivo financeiro, quando comparado com aquele cujo valor é embolsado em contraprestação a determinado esforço. Segundo os autores, aquele que aufere o incentivo através de doação tende a adotar uma postura mais agressiva, o que também pode distorcer os resultados. 
No mais, segundo Friedman e Sunder (1994), no campo experimental de avaliação de comportamentos, muitos pesquisadores entendem que o incentivo financeiro é desnecessário e que solicitar aos participantes para fazer seu melhor é perfeitamente aceitável para atingir um resultado válido.

Esclarecidos alguns pontos fundamentais e cuidados adotados na condução do experimento, convém voltar a detalhar suas etapas. No seu início, os participantes receberam as devidas instruções, junto com a descrição do país fictício que se caracterizava por possuir uma baixa confiança dos contribuintes no Governo e baixo poder das autoridades para impor as obrigações tributárias. Após a leitura dessas informações, os participantes foram randomicamente distribuídos em três diferentes grupos:

a) Grupo recompensas: são simuladas recompensas efetivas e potenciais, inclusive através de previsão em lei, incentivando o comportamento obediente da legislação fiscal;

b) Grupo punições: são simuladas auditorias e punições, no caso da prática de sonegação fiscal;

c) Grupo controle: não há qualquer manipulação do ambiente.

Essa fase tem por objetivo avaliar o aprendizado e o comportamento do contribuinte em relação a duas diferentes políticas públicas fiscais: a) uma baseada em políticas que podem gerar consequências não aversivas para os contribuintes, por meio de recompensas efetivas e potenciais, incentivando o cumprimento suas obrigações tributárias; e b) outra baseada em políticas que podem gerar consequências aversivas por meio de auditorias e punições em desfavor dos contribuintes, desincentivando a conduta evasiva. Dessa forma, foi possível avaliar a aplicabilidade dos ensinamentos da Análise do Comportamento em busca de mais conformidade fiscal, respondendo a questão de pesquisa correspondente. 
O grupo controle foi introduzido para comparação, de modo a garantir mais validade interna e externa ao experimento. A constatação de diferenças estatísticas significantes entre o grupo controle e os demais constitui evidência significativa de validade e sensibilidade do instrumento.

Da mesma forma como foi realizado na primeira etapa previamente relatada, os participantes tiveram que informar o valor a pagar de imposto de renda durante dez períodos consecutivos. Entretanto, aqueles que integravam o grupo recompensas e o grupo punições receberam os inputs na forma descrita no Apêndice D. Em outras palavras, no experimento as variáveis foram manipuladas de modo a possibilitar a análise de seus efeitos, com exceção, frise-se, do grupo controle.

Em relação aos inputs oferecidos no grupo recompensas durante o os dez períodos, embora o experimento procure criar uma conjuntura próxima da realidade, foram incluídas situações potenciais, mas que muitas vezes não se repetem na vida real. Isso, todavia, é realizado justamente porque o experimento tem por intuito aparentar práticas tributárias que não necessariamente ocorrem atualmente, mas são simuladas. Libby et al. (2002) defendem essa metodologia, afirmando que pode ser sábio criar níveis que não são realísticos durante o experimento.

Outro cuidado em relação aos inputs é que eles eram apresentados em apenas alguns períodos, e não em todos eles. Com isso, evita-se o chamado "efeito de demanda", no qual o excesso de informações repetidas faz com que o participante perceba qual a resposta desejada pelo pesquisador, o que também poderia enviesar o resultado (Libby et al., 2002).

No que tange à ordem em que os inputs foram dados aos participantes, adotou-se a cautela necessária para que todos recebessem as informações no mesmo período, independentemente do grupo. Isso porque eventual aleatoriedade de inputs dificultaria a comparação entre os grupos. Para exemplificar, imaginemos um participante que receba uma 
punição no primeiro período. Essa punição poderia influenciar sua opção de recolhimento para os períodos seguintes, efeito predito por Kastlunger, Kirchler, Mittone e Pitters (2009). Enquanto isso, outro sujeito que somente recebesse punições em períodos posteriores poderia manter certo nível de sonegação fiscal até então, prejudicando a comparabilidade do estudo. Libby et al. (2002) afirmam que esse balanceamento é importante para que os efeitos do tratamento não se confundam com efeitos de ordem.

\subsubsection{Outros cuidados na condução do experimento}

Ao optar pela utilização de experimentos para avaliar teorias empiricamente, o pesquisador deve estar ciente de que o estudo deve se pautar pela avaliação criteriosa dos detalhes que o comporão. No presente estudo procurou-se seguir esse "norte", avaliando, antes da aplicação do experimento, todos os detalhes envolvidos no processo, inclusive a realização de teste-piloto exploratório. Bêrni, Abegg e Marquetti (2015) sintetizam que o testepiloto exploratório é de suma importância para o desenvolvimento de pesquisa científica e tem por objetivo "...coletar ideias, conceitos e percepções que podem aprofundar e enriquecer o plano original do estudo, além de auxiliar na formulação de hipóteses" (p. 209).

Dessa forma, antes da aplicação que serviu de base para os resultados, o experimento foi reproduzido no decorrer do segundo semestre de 2013 para a turma de mestrado da FEA/USP, na disciplina "Tópicos Contemporâneos de Contabilidade", oportunidade em que as regras, instruções e perguntas foram debatidas, avaliadas e revisadas, minimizando-se, assim, a possibilidade de questões mal formuladas ou ininteligíveis.

Ademais, embora possa parecer enfadonho, é imprescindível reiterar que os estudos que envolvem o comportamento humano possuem dificuldade potencializada em razão da variabilidade dos resultados. O ser humano é afetado por questões culturais, crenças, valores, medos, sentimentos, cujas emoções podem afetar o resultado de um experimento. Essa dificuldade foi assim relatada por Martins e Theóphilo (2009): 
É tarefa deveras complexa e difícil medir construtos desta natureza - comuns nos estudos comportamentais -, pois uma atitude é um construto que existe na mente dos indivíduos, não podendo ser observada diretamente, como o peso ou a altura. (p. 19)

Linha de raciocínio similar é apresentada por Cozby (2003), que expõe a complexidade de se asseverar com precisão a causa de determinado comportamento. É por isso que o autor assim relata a raridade de conclusões incontestáveis e a ocorrência de contradições entre resultados:

O requisito "necessário e suficiente" para estabelecer a causa é raro em Psicologia. Sempre que psicólogos afirmam que há uma causa necessária e suficiente para o comportamento, logo surgem pesquisas mostrando que não é bem assim. (p. 97)

Esses desafios não podem servir de vetor para a renúncia de pesquisas que envolvam o estudo do comportamento humano, mormente levando-se em conta sua importância para todas as áreas acadêmicas, pois, afinal, onde há ciência, há seres humanos e, portanto, comportamento, em especial no campo das ciências sociais aplicadas. Porém, reconhecer a dificuldade desse desafio é fundamental para o rigor do procedimento metodológico da pesquisa, sem que isso signifique um desestímulo a esse campo do conhecimento. Em verdade, o movimento deve ser justamente o contrário: dada a complexidade da temática, há necessidade de mais e mais pesquisas que colaborem com o processo científico de gradual construção do conhecimento.

Considerando-se esses aspectos, merece destaque a questão da validade do construto proposto para a pesquisa. Sobre o tema, Lipsey e Hurley (2009) sustentam ser fundamental para uma correta conclusão sobre os resultados da pesquisa que o design do experimento tenha validade, que se refere à probabilidade de que o efeito detectado é o interesse em estudo.

Um construto cujo comportamento se pretenda avaliar merece e não dispensa uma contínua pesquisa, devendo ser frequentemente complementado e revalidado, seja pelo 
mesmo pesquisador ou, ainda mais indicado, por outros acadêmicos. Trata-se, tão-somente, do início de um processo ou sua continuação, jamais podendo ser considerado de forma singular e definitiva, mas, sim, inserido num amplo conjunto de estudos sobre o tema. Cozby (2003) afirma com precisão que dificilmente a validade de um instrumento é atingida por um único estudo. Segundo o autor, há a necessidade de uma gama de pesquisas que possam confrontar se o construto tem validade para avaliar determinada teoria. O processo, segue aduzindo, vai sendo aprimorado com o decorrer das pesquisas, surgindo novas medidas que corrigem eventuais problemas e possibilitam uma compreensão gradual e mais abrangente de diversas variáveis estudadas.

É de se constatar, no entanto, ao menos a validade aparente do construto, eis que parte dele já foi intensamente utilizada em pesquisas estrangeiras, e a parte adicional proposta no presente estudo está fundada em ciência válida e intensamente discutida (Análise do Comportamento). Além disso, como dito alhures, a inclusão de grupo controle colabora na avaliação dos resultados e reforça a validade do instrumento, especialmente quando analisados os resultados, pois a diferença entre os grupos, após a manipulação do ambiente, é justificada pela intervenção.

Outra preocupação relevante, associada à validade em pesquisas em que o participante deve fazer escolhas que envolvam temas delicados, diz respeito à predisposição de resposta, ou seja, aquela em que o participante tende a responder as questões de acordo com a conveniência social, apresentando-se de uma maneira favorável (Cozby, 2003). Em outras palavras, o participante tende a apresentar respostas socialmente aceitáveis.

Efetivamente, esse risco está presente no caso em estudo, que aborda aspectos sobre observância fiscal que, obviamente, esbarram em questões éticas, morais e até mesmo criminais. É cediço que a sonegação fiscal é um comportamento, em tese, socialmente reprovável, inclusive podendo se enquadrar como crime de acordo com a legislação penal 
brasileira $^{22}$. Diante desse contexto, durante a realização do experimento se adotaram algumas cautelas para evitar ou, ao menos, minimizar os efeitos da predisposição de resposta.

Em primeiro lugar, foi garantido o sigilo aos participantes. Além do compromisso do pesquisador, cada participante pôde responder o questionário sem precisar identificar seu nome, em razão do fornecimento de senha individual que garantia o acesso aos dados tãosomente ao pesquisador.

Dessa forma, acredita-se que o efeito da predisposição de resposta foi, tanto quanto possível, minimizado. Sobre o tema, Jourard (1969) sugere que as pessoas provavelmente mentem mais quando não confiam no pesquisador. Como consequência, compete a ele comunicar aberta e honestamente os objetivos e usos da pesquisa, prometer informar os resultados prontamente e assegurar o anonimato, de maneira a aumentar a probabilidade de que os participantes venham a fornecer respostas honestas. Durante a realização do teste, essas preocupações estiveram sempre presentes.

${ }^{22}$ A lei no 4.729, de 14 de julho de 1965, trata do crime de sonegação fiscal. 


\section{DOS RESULTADOS}

\subsection{Da pesquisa on-line}

A primeira etapa do estudo objetivou analisar os resultados da pesquisa on-line, visando responder a primeira questão de pesquisa, objeto do tópico 1.4, testando as hipóteses $\mathrm{H}_{1}$ e $\mathrm{H}_{2}$ citadas no tópico 1.5. Isso será possível através da avaliação de associação das variáveis "confiança" e "poder" nas questões referentes a observância voluntária (Q1 a Q8) e observância forçada (Q9 a Q14), descritas no Apêndice C.

Adicionalmente, e apenas para possibilitar uma análise mais profunda dos dados, foi avaliado o efeito das variáveis independentes "confiança" e "poder" no valor médio pago em impostos (média dos dez períodos), nesse caso considerado como variável dependente. Embora não se pretenda, nesse particular, testar qualquer hipótese metodológica, entendeu-se que essa avaliação possibilita uma discussão mais ampla da questão de pesquisa.

\subsubsection{Da metodologia estatística}

Para que o estudo venha a atingir seus objetivos, além de técnicas básicas de análise exploratória de dados, como média, desvio-padrão e frequências absoluta e relativa, foram utilizadas a Manova, a Anova com comparações múltiplas de Tukey, a Análise Fatorial e os testes de Mann-Whitney e Kruskal-Wallis.

A Manova, chamada de Mancova quando há presença de variáveis de controle no estudo, é uma técnica extensiva da Análise de Variância (Anova), e que possibilita mensurar a diferença entre grupos considerando mais de uma variável dependente e um conjunto de variáveis categóricas que agem como variáveis independentes, sendo especialmente indicada quando o pesquisador deseja avaliar se a manipulação de uma ou mais variáveis independentes afeta alguma variável dependente (Hair, Black, Babin, Anderson, \& Tatham, 2006). 
A técnica foi utilizada para avaliar a associação dos fatores confiança, poder, interação de confiança e poder e variáveis de controle (sexo e idade) com a pontuação nas questões de observância voluntária (Q1 a Q8) e forçada (Q9 a Q14). Em outras palavras, confiança e poder foram utilizadas como variáveis independentes e observância voluntária e observância forçada como variáveis dependentes, incluindo-se sexo e idade como variáveis de controle. Antes do ajuste do modelo, foi calculado o coeficiente Alpha de Cronbach para avaliar se as questões referentes a um mesmo tipo de observância apresentam uma estrutura de correlação.

O Alpha de Cronbach é empregado para estimar a confiabilidade de um questionário aplicado em uma pesquisa. O coeficiente mede a correlação entre respostas em um questionário mediante exame daquelas dadas pelos participantes, apresentando uma correlação média entre as perguntas (Hora, Monteiro, \& Arica, 2010).

Valores de Alpha de Cronbach superiores a 0,6 indicam que o instrumento é confiável e produz mensurações estáveis e consistentes. Valores inferiores a 0,6 indicam que o instrumento apresenta uma variabilidade heterogênea entre seus itens e, portanto, poderá levar a conclusões equivocadas (Murphy \& Davidshofer, 1988).

Para validar os resultados da Manova, foi empregada uma análise fatorial seguida da Anova para as questões de observância voluntária (Q1 a Q8) e observância forçada (Q9 a Q14). A análise fatorial é uma técnica multivariada que possibilita a redução de um conjunto de variáveis por meio da identificação de fatores comuns que são variáveis latentes mensuradas através daquelas observáveis do estudo (Fávero, Belfiore, Silva, \& Chan, 2009). Dentre os diversos objetivos da análise fatorial, conforme explicam Corrar, Paulo e Dias (2007), destaca-se a criação de um ou poucos fatores que descrevam um conjunto maior de variáveis originais.

A Anova, denominada Ancova quando presente variáveis de controle, é um teste paramétrico de análise de Variância. Utiliza a igualdade de médias para verificar se os fatores 
têm como consequência mudanças sistemáticas nas variáveis de interesse, ou seja, se as variáveis independentes afetam as dependentes (Martins \& Domingues, 2011), porém incluindo na avaliação variáveis de controle, no caso da Ancova.

Dessa forma, a técnica foi utilizada para avaliar se há efeito dos fatores confiança, poder, interação de confiança e poder e variáveis de controle (sexo e idade) no valor médio pago em impostos. Nos casos em que houve significância estatística da interação, utilizou-se o teste de comparações múltiplas de Tukey para identificar os grupos diferentes. Segundo Hair et al. (2006), a técnica é utilizada para determinar se as amostras de dois ou mais grupos referemse a populações de médias iguais.

Para responder a esse mesmo objetivo, foi aplicado o teste de Mann-Whitney para confiança e poder, separadamente, além do teste de Kruskal-Wallis para a interação, que são abordagens não paramétricas, utilizadas para confrontar os resultados do teste paramétrico.

O teste de Mann-Whitney é um teste não paramétrico que tem por objetivo a comparação de duas amostras independentes. Por não demandar qualquer das suposições sobre a distribuição populacional ou suas variâncias, é indicado como alternativa ao teste paramétrico de igualdade de média t-Student (Martins \& Domingues, 2011).

O teste de Kruskal-Wallis, ao seu turno, é não paramétrico equivalente ao teste $F$ da Anova, tendo por objetivo detectar a existência de diferença significativa entre as médias de $k$ amostras diferentes (Martins \& Domingues, 2011). É empregado, portanto, em substituição à Análise de Variância, quando não satisfeitos os requisitos necessários para suportar as suposições do modelo da Anova.

Todos os testes de hipóteses desenvolvidos neste estudo consideraram uma significância de 5\%; isto é, a hipótese estatística nula foi rejeitada quando $p$-valor foi menor que 0,05 . 


\subsubsection{Da apresentação dos resultados}

Para possibilitar uma compreensão abrangente dos resultados, é conveniente iniciar pela apresentação de uma breve descrição da amostra. Uma vez aplicados todos os critérios de exclusão, o número de observações da base de dados final corresponde a 389 respondentes, com idade média de 34 anos, idade mínima de 17 e máxima de 69. Observa-se uma maior proporção de homens (59\%). A escolaridade é em sua maioria de ensino superior (39\%), seguida por pós-graduação (26\%).

Com relação aos quatro grupos, houve balanceamento suficientemente adequado para possibilitar a aplicação dos testes estatísticos, sendo que o grupo 3 reúne a maior quantidade de respondentes válidos (28\%), enquanto o grupo 2 tem a menor (21\%). Ressalte-se que a diferença entre grupos é comum nesses tipos de estudo, especialmente considerando-se que os participantes são distribuídos aleatoriamente (Neter, Kutner, Nachtshein, \& Wasserman, 1996).

No que tange ao local de residência, a maioria dos respondentes mora em São Paulo $(49,4 \%)$, seguida por Santa Catarina $(30,9 \%)$, sendo que os demais estados, isoladamente, têm representatividade inferior a 5\% da amostra. As Tabelas 1 e 2 mostram com mais detalhes a descrição da amostra.

\begin{tabular}{ccccc}
\hline \multicolumn{5}{c}{ Tabela 1: Análise descritiva da variável idade } \\
\hline$N^{\circ}$ & Média & $\begin{array}{l}\text { Desvio- } \\
\text { padrão }\end{array}$ & Mínimo & Máximo \\
\hline 389 & 34 & 11 & 17 & 69 \\
\hline
\end{tabular}

Fonte: Elaborada pelo autor. 


\begin{tabular}{|c|c|c|c|c|c|}
\hline Variável & Categoria & $\begin{array}{c}\mathrm{N}^{\circ} \text { de } \\
\text { observações }\end{array}$ & $\begin{array}{c}\text { Proporção } \\
\text { (\%) }\end{array}$ & $\begin{array}{c}\mathbf{N}^{\circ} \text { de } \\
\text { observações } \\
\text { acumulado }\end{array}$ & $\begin{array}{c}\text { Proporção } \\
\% \\
\text { acumulado }\end{array}$ \\
\hline \multirow{2}{*}{ Sexo } & Feminino & 158 & 40,6 & 158 & 40,6 \\
\hline & Masculino & 231 & 59,4 & 389 & 100,0 \\
\hline \multirow{6}{*}{ Escolaridade } & Fundamental & 3 & 0,8 & 3 & 0,8 \\
\hline & Médio & 23 & 5,9 & 26 & 6,7 \\
\hline & Superior & 151 & 38,8 & 177 & 45,5 \\
\hline & Pós-Graduado & 102 & 26,2 & 279 & 71,7 \\
\hline & Mestrado & 88 & 22,6 & 367 & 94,3 \\
\hline & Doutorado & 22 & 5,7 & 389 & 100,0 \\
\hline \multirow{4}{*}{ Grupo } & Alta Confiança e Muita Força & 96 & 24,7 & 96 & 24,7 \\
\hline & Alta Confiança e Pouca Força & 81 & 20,8 & 177 & 45,5 \\
\hline & Baixa Confiança e Muita Força & 110 & 28,3 & 287 & 73,8 \\
\hline & Baixa Confiança e Pouca Força & 102 & 26,2 & 389 & 100,0 \\
\hline \multirow{17}{*}{ UF } & Acre & 3 & 0,8 & 3 & 0,8 \\
\hline & Amazonas & 4 & 1,0 & 7 & 1,8 \\
\hline & Bahia & 2 & 0,5 & 9 & 2,3 \\
\hline & Espírito Santo & 3 & 0,8 & 12 & 3,1 \\
\hline & Goiás & 3 & 0,8 & 15 & 3,9 \\
\hline & Maranhão & 1 & 0,3 & 16 & 4,1 \\
\hline & Mato Grosso & 4 & 1,0 & 20 & 5,1 \\
\hline & Minas Gerais & 12 & 3,1 & 32 & 8,2 \\
\hline & Pará & 2 & 0,5 & 34 & 8,7 \\
\hline & Paraíba & 7 & 1,8 & 41 & 10,5 \\
\hline & Paraná & 19 & 4,9 & 60 & 15,4 \\
\hline & Pernambuco & 6 & 1,5 & 66 & 17,0 \\
\hline & Rio de Janeiro & 3 & 0,8 & 69 & 17,7 \\
\hline & Rio Grande do Norte & 2 & 0,5 & 71 & 18,2 \\
\hline & Rio Grande do Sul & 6 & 1,5 & 77 & 19,8 \\
\hline & Santa Catarina & 120 & 30,9 & 197 & 50,6 \\
\hline & São Paulo & 192 & 49,4 & 389 & 100,0 \\
\hline
\end{tabular}

Fonte: Elaborada pelo autor.

Em relação aos critérios de exclusão, foram adotadas as seguintes etapas:

1. exclusão dos dados relacionados aos testes feitos pelo desenvolvedor do software e pelo pesquisador (filtro por nome);

2. exclusão dos participantes que preencheram apenas parcialmente a pesquisa, seja não respondendo as questões ou a totalidade dos períodos;

3. exclusão dos participantes que responderam equivocadamente as questões de aderência à pesquisa, conforme explicado no tópico 3.2.1; 
4. exclusão de um participante cuja idade declinada era irreal (aproximadamente 800 anos)

A Tabela 3 revela a distribuição final das observações, descrevendo as exclusões realizadas conforme etapas acima descritas.

\begin{tabular}{lc}
\hline \multicolumn{2}{c}{ Tabela 3 - Distribuição das observações em cada etapa de aplicações de filtro de } \\
exclusão
\end{tabular}

Fonte: Elaborada pelo autor.

Restaram, portanto, 389 respondentes, sendo um número de observações bastante significativo, que propicia a redução de erro de amostragem e aumenta a sensibilidade (poder) do teste (Hair et al. 2006).

Em relação às questões de observância (Q1 a Q14), verifica-se que a maioria relacionada com a observância voluntária (Q1 a Q8) apresentaram maiores proporções em concordo totalmente (resposta $=5$ ), representando $54 \%$ das respostas na questão Q1, $44 \%$ na questão Q2, 49\% na questão Q3, 40\% na questão Q4, 44\% na questão Q5 e 53\% na questão Q8.

Apenas nas perguntas Q6 e Q7 não foi observada maior pontuação em concordo totalmente. No entanto, nesses dois casos a maior proporção ocorreu em concordo parcialmente (resposta $=4$ ), sendo $33 \%$ na questão Q6 e $29 \%$ na questão Q7, indicando uma boa pontuação quanto à observância voluntária. 
Para a observância forçada (Q9 a Q14), nota-se que as maiores pontuações foram predominantes, mas em menores proporções se comparadas às questões da observância voluntária, com $43 \%$ de concordo totalmente na questão 9, 34\% na questão Q10, 32\% na questão Q 12 e $31 \%$ na questão Q 14 . A questão Q 11 apresentou $27 \%$ em nem concordo e nem discordo e $26 \%$ em concordo totalmente, enquanto a questão Q 12 apresentou $23 \%$ em concordo parcialmente.

A Tabela 4 mostra as frequências e proporções relativas a cada questão.

\begin{tabular}{|c|c|c|c|c|c|c|c|}
\hline \multirow{2}{*}{ Compliance } & \multirow{2}{*}{ Questão } & \multirow{2}{*}{ Estatística } & \multicolumn{5}{|c|}{ Resposta } \\
\hline & & & 1 & 2 & 3 & 4 & 5 \\
\hline \multirow{16}{*}{ Voluntário } & Q1 & $\mathrm{N}$ & 3 & 23 & 24 & 127 & 212 \\
\hline & & $\%$ & 0,8 & 5,9 & 6,2 & 32,6 & 54,5 \\
\hline & Q2 & $\mathrm{N}$ & 42 & 43 & 24 & 108 & 172 \\
\hline & & $\%$ & 10,8 & 11,1 & 6,2 & 27,8 & 44,2 \\
\hline & Q3 & $\mathrm{N}$ & 40 & 43 & 17 & 100 & 189 \\
\hline & & $\%$ & 10,3 & 11,1 & 4,4 & 25,7 & 48,6 \\
\hline & Q4 & $\mathrm{N}$ & 58 & 66 & 28 & 83 & 154 \\
\hline & & $\%$ & 14,9 & 17,0 & 7,2 & 21,3 & 39,6 \\
\hline & Q5 & $\mathrm{N}$ & 45 & 53 & 12 & 108 & 171 \\
\hline & & $\%$ & 11,6 & 13,6 & 3,1 & 27,8 & 44,0 \\
\hline & Q6 & $\mathrm{N}$ & 72 & 65 & 36 & 129 & 87 \\
\hline & & $\%$ & 18,5 & 16,7 & 9,3 & 33,2 & 22,4 \\
\hline & Q7 & $\mathrm{N}$ & 96 & 53 & 26 & 112 & 102 \\
\hline & & $\%$ & 24,7 & 13,6 & 6,7 & 28,8 & 26,2 \\
\hline & Q8 & $\mathrm{N}$ & 9 & 39 & 15 & 119 & 207 \\
\hline & & $\%$ & 2,3 & 10,0 & 3,9 & 30,6 & 53,2 \\
\hline \multirow{12}{*}{ Forçado } & Q9 & $\mathrm{N}$ & 72 & 67 & 33 & 50 & 167 \\
\hline & & $\%$ & 18,5 & 17,2 & 8,5 & 12,9 & 42,9 \\
\hline & Q10 & $\mathrm{N}$ & 56 & 64 & 65 & 73 & 131 \\
\hline & & $\%$ & 14,4 & 16,5 & 16,7 & 18,8 & 33,7 \\
\hline & Q11 & $\mathrm{N}$ & 61 & 63 & 104 & 58 & 103 \\
\hline & & $\%$ & 15,7 & 16,2 & 26,7 & 14,9 & 26,5 \\
\hline & Q12 & $N$ & 75 & 84 & 82 & 90 & 58 \\
\hline & & $\%$ & 19,3 & 21,6 & 21,1 & 23,1 & 14,9 \\
\hline & Q13 & $\mathrm{N}$ & 26 & 67 & 55 & 115 & 126 \\
\hline & & $\%$ & 6,7 & 17,2 & 14,1 & 29,6 & 32,4 \\
\hline & Q14 & $\mathrm{N}$ & 46 & 65 & 69 & 90 & 119 \\
\hline & & $\%$ & 11,8 & 16,7 & 17,7 & 23,1 & 30,6 \\
\hline
\end{tabular}

Fonte: Elaborada pelo autor. 
Para testar as hipóteses $\mathrm{H}_{1}$ e $\mathrm{H}_{2}$, cujo objetivo é buscar respostas para a primeira questão da pesquisa descrita no tópico 1.4, foram utilizados dois modelos de Manova, sendo um considerando as oito questões referentes à observância voluntária (Q1 a Q8) e uma contendo as seis questões de observância forçada (Q9 a Q14). Os dois modelos visam avaliar a associação entre os fatores confiança, poder e interação entre poder e confiança na presença de variáveis de controle (sexo e idade) quanto à pontuação nas questões de observância.

Antes do ajuste do modelo Manova, foi calculado o coeficiente Alpha de Cronbach, que registrou 0.74 para observância voluntária e 0.67 para observância forçada, que são valores aceitáveis aplicados nesses tipos de estudo (Murphy \& Davidshofer, 1988).

Os resultados dos testes demonstram que a confiança está associada à observância voluntária ( $p$-valor < 0.0001), sendo que a alta confiança apresenta maior observância voluntária. Verificou-se também uma associação da observância voluntaria com a idade ( $p$-valor de 0.0020 ), sendo que quanto maior a idade, maior a observância voluntária (correlações positivas). A Tabela 5 reproduz esses resultados.

Tabela 5 - Manova para observância voluntária

\begin{tabular}{lcl}
\hline \multicolumn{1}{c}{ Variável } & Estatística $\mathrm{F}$ & $\mathrm{p}$-valor \\
\hline Confiança & 61.41 & $<.0001$ \\
Força & 1.22 & 0.2879 \\
Sexo & 0.94 & 0.4855 \\
Idade & 3.11 & 0.0020 \\
Confiança*Força & 0.55 & 0.8192 \\
\hline
\end{tabular}

Fonte: Elaborada pelo autor.

Em relação à observância forçada, o resultado demonstra significância de confiança (pvalor $<0.0001)$, poder $(p$-valor $<0.0001)$ e idade $(p$-valor $=0.0033)$. Maior confiança está mais associada à menor observância forçada, maior poder está associado à maior observância forçada e maiores idades estão associadas à maior observância forçada. A Tabela 9 demonstra tais resultados. 
Tabela 6 - Manova para observância forçada

\begin{tabular}{lcc}
\hline \multicolumn{1}{c}{ Variável } & Estatística F & p-valor \\
\hline Confiança & 50.81 & $<.0001$ \\
Força & 129.27 & $<.0001$ \\
Sexo & 0.08 & 0.9983 \\
Idade & 3.33 & 0.0033 \\
Confiança*Força & 1.25 & 0.2794 \\
\hline
\end{tabular}

Fonte: Elaborada pelo autor.

Em nenhum dos casos houve efeito de interação de poder e confiança, já que o p-valor ficou acima de 0.05 em ambos os casos.

Na Tabela 7 é possível ter uma compreensão mais abrangente dos resultados com a análise descritiva das questões relativas à observância voluntária e forçada e à interação com as variáveis confiança e poder.

\begin{tabular}{|c|c|c|c|c|c|c|c|c|c|c|c|c|c|c|c|}
\hline & \multirow[b]{2}{*}{ Estatística / Variável } & \multicolumn{8}{|c|}{ Compliance Voluntário } & \multicolumn{6}{|c|}{ Compliance Forçado } \\
\hline & & Q1 & Q2 & Q3 & Q4 & Q5 & Q6 & Q7 & Q8 & Q9 & Q10 & Q11 & Q12 & Q13 & Q14 \\
\hline \multicolumn{16}{|l|}{ Média } \\
\hline \multirow{2}{*}{ Confiança } & Alta & 4,6 & 4,3 & 4,5 & 4,7 & 4,7 & 3,9 & 2,3 & 4,6 & 3,4 & 2,5 & 2,6 & 2,6 & 3,4 & 2,9 \\
\hline & Baixa & 4,1 & 3,4 & 3,4 & 2,6 & 3,0 & 2,7 & 3,9 & 3,9 & 3,5 & 4,2 & 3,7 & 3,2 & 3,8 & 3,9 \\
\hline \multirow{3}{*}{ Força } & Muita & 4,4 & 3,8 & 3,9 & 3,5 & 3,7 & 3,2 & 3,2 & 4,3 & 4,7 & 3,8 & 3,4 & 2,9 & 4,0 & 3,5 \\
\hline & Pouca & 4,3 & 3,9 & 3,9 & 3,6 & 3,9 & 3,3 & 3,1 & 4,2 & 2,1 & 3,0 & 2,9 & 2,9 & 3,3 & 3,4 \\
\hline & Alta Confiança e Muita Força & 4,7 & 4,3 & 4,6 & 4,7 & 4,7 & 3,9 & 2,4 & 4,7 & 4,6 & 2,8 & 2,8 & 2,7 & 3,6 & 3,0 \\
\hline Confiança* & Alta Confiança e Pouca Força & 4,6 & 4,3 & 4,4 & 4,6 & 4,7 & 4,0 & 2,2 & 4,5 & 2,0 & 2,1 & 2,3 & 2,5 & 3,1 & 2,8 \\
\hline \multirow[t]{2}{*}{ Força } & Baixa Confiança e Muita Força & 4,1 & 3,4 & 3,4 & 2,5 & 2,9 & 2,5 & 3,9 & 3,9 & 4,7 & 4,6 & 4,0 & 3,1 & 4,2 & 3,9 \\
\hline & Baixa Confiança e Pouca Força & 4,0 & 3,5 & 3,4 & 2,7 & 3,2 & 2,8 & 3,8 & 3,9 & 2,2 & 3,7 & 3,4 & 3,3 & 3,4 & 3,8 \\
\hline \multicolumn{16}{|l|}{ Corr } \\
\hline & Idade & 0,07 & 0,18 & 0,12 & $\underline{0,12}$ & 0.15 & 0,11 & $-0,02$ & 0 , & 0,0 & $\overline{0,0}$ & 5 & 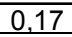 & & \\
\hline
\end{tabular}

Fonte: Elaborada pelo autor.

Para validar os resultados da Manova, já que a suposição de normalidade multivariada e de homoscedasticidade não foi analisada devido a sua complexidade computacional, foi empregada a análise fatorial para as questões de observância voluntária e para as questões de observância forçada, seguida da Anova, cujas normalidade e homoscedasticidade não 
apresentaram grandes distorções. Pretende-se, assim, suprir a ausência daquelas suposições esperadas da Manova, confirmando os seus resultados.

A aplicação dessa metodologia para as questões de observância voluntária e observância forçada possibilita mensurar a variável latente que resume as questões de observância voluntária (Q1 a Q8) e forçada (Q9 a Q14). Dessa maneira é possível aplicar Anova univaridada para esses fatores e, uma vez validadas as suposições do modelo, pode-se inferir sobre a relação entre as variáveis explicativas analisadas (confiança, força, sexo e idade) e as variáveis de interesse (fator de observãncia voluntária e observância forçada).

Para definir o fator observância voluntária, foram consideradas as questões Q1 a Q8. A análise fatorial gerou somente um fator com autovalor superior a 1 , sendo que esse fator explica $50 \%$ da variabilidade total das oito questões. Esse fator apresenta apenas quatro questões com peso superior a 0.4, na construção do fator, que são as questões Q3, Q4, Q5 e Q8; as demais não foram selecionadas para a composição do fator.

\begin{tabular}{lcc}
\hline \multicolumn{3}{c}{ Tabela 8 - Análise fatorial para observância voluntária } \\
\hline Fator & Questão & Peso no fator 1 \\
\hline \multirow{4}{*}{ Fator 1 } & Q3 & 0,77 \\
& Q4 & 0,75 \\
& Q5 & 0,76 \\
Q8 & 0,49 \\
\hline \multirow{4}{*}{ Sem fator } & Q1 \\
& Q2 \\
& Q6 \\
Autovalor & Q7 \\
\% variabilidade explicada & \\
\% acumulado de variabilidade & 4,02 \\
\hline
\end{tabular}

Fonte: Elaborada pelo autor.

Para avaliar se há efeito de confiança, força e confiança*força no fator observância voluntária, foi ajustada uma Anova com variáveis concomitantes, idade e sexo. Para atingir a normalidade suposta no modelo, foi considerada a transformação (fator+4) ${ }^{2}$. 


\begin{tabular}{lrr}
\hline \multicolumn{3}{c}{ Tabela 9 - Anova para observância voluntária (fator1 +4$)^{2}$} \\
\hline Confianca & Estatística F & p-valor \\
\hline Forca & 156,36 & $<.0001$ \\
Sexo & 0,1 & 0,7472 \\
Idade & 4,46 & 0,0353 \\
Confianca*Forca & 10,12 & 0,0016 \\
\hline
\end{tabular}

Fonte: Elaborada pelo autor.

\begin{tabular}{|c|c|c|}
\hline \multicolumn{3}{|c|}{ Tabela 10 - Média do fator 1 a partir das questões } \\
\hline \multicolumn{3}{|l|}{ Confiança } \\
\hline & Alta & 0,58 \\
\hline & Baixa & $-0,48$ \\
\hline \multicolumn{3}{|l|}{ Força } \\
\hline & Muita & $-0,01$ \\
\hline & Pouca & 0,01 \\
\hline \multirow[t]{5}{*}{ Confiança } & Força & \\
\hline & Muita & 0,62 \\
\hline & Pouca & 0,53 \\
\hline & Muita & $-0,57$ \\
\hline & Pouca & $-0,4$ \\
\hline
\end{tabular}

Fonte: Elaborada pelo autor.

Observa-se que somente a variável confiança foi significativa ( $p$-valor $<0.001$ ), sendo que a alta confiança está associada à maior observância voluntária. Esse resultado corrobora o resultado da análise Manova para a observância voluntária.

Para definir os fatores latentes referentes à observância forçada, foram consideradas as questões Q9 a Q14. Nesse caso, a análise fatorial gerou dois fatores com autovalor superior a 1, sendo que esses fatores explicam, conjuntamente, $57 \%$ da variabilidade total das seis questões. O primeiro fator é composto pelas questões Q10 e Q11 e o segundo é composto pelas questões Q9 e Q13; as questões Q12 e Q14 não foram selecionadas para a composição de nenhum dos dois fatores. 


\begin{tabular}{llcl}
\hline \multicolumn{3}{c}{ Tabela 11 - Análise fatorial para observância forçada } \\
\hline \multirow{2}{*}{ Fator } & \multirow{2}{*}{ Questão } & Peso no Fator 1 Peso no Fator 2 \\
\hline \multirow{2}{*}{ Fator 1 } & Q10 & 0,70 & \\
& Q11 & 0,89 & 0,78 \\
\multirow{2}{*}{ Fator 2 } & Q9 & & 0,80 \\
& Q13 & & \\
\hline \multirow{2}{*}{ Sem fator Q12 } & Q14 & & 1,10 \\
Autovalor & 2,33 & 0,18 \\
\% variabilidade explicada & 0,39 & 0,57 \\
\hline
\end{tabular}

Fonte: Elaborada pelo autor.

Para avaliar se há efeito de confiança, força e confiança*força no fator observância forçada, foram ajustadas duas Anova com variáveis concomitantes, idade e sexo. Para atingir a normalidade suposta no modelo, foi considerada a transformação (fator+4) ${ }^{2}$ para o primeiro fator, enquanto para o segundo não foi necessário usar transformação, já que a normalidade foi aceita nos dados brutos.

Na Anova do fator 1, tanto a variável de força quanto a variável de confiança foram significativas, sendo que muita força está associada à maior observância forçada, enquanto alta confiança se associa à baixa observância forçada. Já para o segundo fator, somente a variável de força foi significativa, sendo que, novamente, alta força está relacionada à maior observância forçada.

\begin{tabular}{lrr}
\hline \multicolumn{3}{c}{ Tabela 12 - Anova para observância forçada (fator1 +4$)^{2}$} \\
\hline \multicolumn{1}{c}{ Variável } & Estatística F & p-valor \\
\hline Confianca & 139,29 & $<.0001$ \\
Forca & 36,71 & $<.0001$ \\
Sexo & 0,05 & 0,8222 \\
Idade & 0,85 & 0,3578 \\
Confianca*Forca & 0,42 & 0,5171 \\
\hline
\end{tabular}

Fonte: Elaborada pelo autor. 


\begin{tabular}{lrr}
\hline \multicolumn{3}{c}{ Tabela 13 - Anova para observância forçada fator 2 } \\
\hline \multicolumn{1}{c}{ Variável } & Estatística F & p-valor \\
\hline Confianca & 0,34 & 0,5589 \\
Forca & 266,45 & $<.0001$ \\
Sexo & 0,02 & 0,8877 \\
Idade & 1,05 & 0,3068 \\
Confianca*Forca & 0,86 & 0,3541 \\
\hline
\end{tabular}

Fonte: Elaborada pelo autor.

\begin{tabular}{|c|c|c|c|}
\hline \multicolumn{4}{|c|}{$\begin{array}{l}\text { Tabela } 14 \text { - Média do fator } 1 \text { e } 2 \text { obtidos a partir } \\
\text { das questões de observância forçada para } \\
\text { categorias de confiança, força e confiança*força }\end{array}$} \\
\hline Efeito & & Fator 1 & ator 2 \\
\hline \multicolumn{4}{|l|}{ Confiança } \\
\hline Alta & & $-0,55$ & $-0,01$ \\
\hline Baixa & & 0,46 & 0,01 \\
\hline \multicolumn{4}{|l|}{ Força } \\
\hline Muita & & 0,23 & 0,61 \\
\hline Pouca & & $-0,26$ & $-0,68$ \\
\hline Confiança & Força & & \\
\hline \multirow[t]{2}{*}{ Alta } & Muita & $-0,32$ & 0,54 \\
\hline & Pouca & $-0,82$ & $-0,66$ \\
\hline \multirow[t]{2}{*}{ Baixa } & Muita & 0,71 & 0,66 \\
\hline & Pouca & 0,19 & $-0,7$ \\
\hline
\end{tabular}

Fonte: Elaborada pelo autor.

Observou-se que os resultados para observância forçada confirmam aqueles verificados no modelo Manova, ainda que para o segundo fator a variável confiança não tenha sido significativa, o que, por outro lado, corrobora os resultados observados na literatura.

Adicionalmente, para possibilitar uma análise mais robusta, avaliou-se o efeito dos fatores confiança e poder no valor de imposto pago (média dos dez períodos). Foi utilizado um modelo Ancova, que é uma análise de variância com varáveis de controle. Diversas transformações foram testadas na busca de se normalizar a variável resposta (imposto médio dos dez períodos), sendo que, pelos testes formais, nenhuma transformação apresentou normalidade. Na otimização da transformação poder $f(x)=\frac{x^{\lambda}-1}{\lambda}$, o valor de $\lambda$ que maximizou a 
normalidade foi 1.8, e, portanto, foi considerada a seguinte transformação: $f($ impos to $)=\frac{\text { Imposto } 1.8}{1.8}$.

De todo modo, devido ao fato de a amostra ser grande, temos então as propriedades de normalidade assintóticas garantidas pelo teorema do limite central na média da variável resposta (Bussab \& Morettin, 2004). Além disso, os modelos de Ancova são robustos a pequenos afastamentos da normalidade (Milone, 2006). Consequentemente, pode-se considerar que os resultados obtidos são confiáveis, mesmo não tendo sido detectadas normalidade e homoscedasticidade via análise gráfica. Evitando-se dúvida, contudo, esses resultados foram validados através da análise bivariada via teste não paramétrico de MannWhitney, para duas categorias, e via teste de Kruskal-Wallis, para mais de duas categorias (interação entre confiança e poder).

Os resultados demonstraram efeito da confiança ( $p$-valor Anova $<0.001$ e MannWhitney igual a 0.0013), poder ( $p$-valor Anova igual a 0.0106 e Mann-Whitney igual a 0.0057) e interação ( $p$-valor Anova igual a 0.0057 e Mann-Whitney < 0.0001) no valor do imposto pago. A maior confiança apresenta maior valor médio pago $(R \$ 694,00)$ e muito poder também apresenta maior pagamento médio ( $\mathrm{R} \$ 680)$. As Tabelas 15 e 16 reproduzem os resultados.

Tabela 15 - Análise descritiva da variável valor médio de imposto pago (10 períodos) nas categorias de confiança, força e interação entre elas

\begin{tabular}{|c|c|c|c|c|c|c|c|c|}
\hline Fator & Categoria & $\begin{array}{c}N^{\circ} \text { de } \\
\text { observações }\end{array}$ & Mediana & Média & $\begin{array}{l}\text { Desvio- } \\
\text { padrão }\end{array}$ & Mínimo & Máximo & $\begin{array}{l}\text { Teste não } \\
\text { paramétrico }\end{array}$ \\
\hline \multirow{2}{*}{ Confiança } & Alta & 177 & 780 & 694 & 193 & 0 & 780 & \multirow{2}{*}{0,0013} \\
\hline & Baixa & 212 & 780 & 610 & 259 & 0 & 780 & \\
\hline \multirow{2}{*}{ Força } & Muita & 206 & 780 & 680 & 207 & 0 & 780 & \multirow{2}{*}{0,0057} \\
\hline & Pouca & 183 & 780 & 613 & 259 & 0 & 780 & \\
\hline \multirow{4}{*}{$\begin{array}{c}\text { Interação } \\
\text { confiança*força }\end{array}$} & Alta Confiança e Muita Força & 96 & 780 & 690 & 201 & 10 & 780 & \multirow{4}{*}{$<.0001$} \\
\hline & Alta Confiança e Pouca Força & 81 & 780 & 698 & 184 & 0 & 780 & \\
\hline & Baixa Confiança e Muita Força & 110 & 780 & 670 & 212 & 0 & 780 & \\
\hline & Baixa Confiança e Pouca Força & 102 & 780 & 546 & 289 & 0 & 780 & \\
\hline
\end{tabular}




\begin{tabular}{lcc}
\hline \hline $\begin{array}{c}\text { Tabela } 16 \text { - Anova da variável valor médio de imposto pago como variável } \\
\text { dependente quanto os fatores independentes confiança, força, } \\
\text { confiança*forca e variáveis de controle sexo e idade }\end{array}$ \\
\hline Variável & Estatística F & p-valor \\
\hline Confiança & 14,02 & 0,0002 \\
Força & 7,11 & 0,0106 \\
Confiança*Força & 7,63 & 0,0057 \\
Sexo & 0,23 & 0,6286 \\
Idade & 0,59 & 0,4425 \\
\hline
\end{tabular}

Fonte: Elaborada pelo autor.

Para a interação, observa-se, na Tabela 17 de comparações múltiplas de Tukey, que somente o grupo de baixa confiança e pouca força difere estatisticamente dos demais (alta confiança e muita força: $p$-valor < 0.0001, alta confiança e bouca força: $p$-valor < 0.0001 e baixa confiança e muita força: $p$-valor $=0.0005)$, e apresenta pagamento médio inferior aos dos demais grupos, com uma média de apenas $R \$$ 546,00, como visto na Tabela 15.

Tabela 17 - Comparações multipals de Tukey para efeito da interação no valor médio de imposto pago

\begin{tabular}{lccc}
\hline \multirow{2}{*}{ Interação } & \multicolumn{3}{c}{ Interação } \\
\cline { 2 - 4 } & $\begin{array}{c}\text { Alta Confiança e } \\
\text { Muita Força }\end{array}$ & $\begin{array}{c}\text { Alta Confiança e } \\
\text { Pouca Força }\end{array}$ & $\begin{array}{c}\text { Baixa Confiança e } \\
\text { Muita Força }\end{array}$ \\
\hline Alta Confiança e Muita Força & 0,9986 & & \\
Alta Confiança e Pouca Força & 0,8825 & 0,8235 & \\
Baixa Confiança e Muita Força & $<.0001$ & $<.0001$ & 0,0005 \\
Baixa Confiança e Pouca Força & & & \\
\hline
\end{tabular}

Fonte: Elaborada pelo autor. 
Os resultados dos testes estatísticos apresentados no tópico precedente possibilitam responder a questão de pesquisa proposta. Com efeito, as hipóteses metodológicas $\mathbf{H}_{\mathbf{1}}$ (Uma alta confiança dos contribuintes no Governo tem como resultado mais observância fiscal voluntária) e $\mathbf{H}_{\mathbf{2}}$ (Uma alta percepção do poder das autoridades fiscais, por parte dos contribuintes, tem como resultado mais observância fiscal forçada) foram confirmadas.

Efetivamente, restou demonstrado, pelos resultados, que a confiança está associada à observância voluntária, sendo que quanto mais alta a confiança no Governo, maior a observância voluntária, confirmando outros estudos sobre o framework citados no tópico 3.2. Vale dizer que, quando o indivíduo confia no Governo, por consequência, tende a obedecer à legislação, cumprindo suas obrigações fiscais de forma mais voluntária. Além disso, o resultado demonstrou que uma maior confiança associa-se à menor observância forçada, significando que quando o indivíduo confia no Governo, o poder de enforcement das autoridades torna-se menos relevante.

Por sua vez, a variável poder das autoridades associou-se à maior observância forçada, significando dizer que, na presença de muito poder, o indivíduo cumpre suas obrigações fiscais em resposta a esse contexto; em outras palavras, forçadamente e não voluntariamente.

Tais resultados possibilitam confirmar as hipóteses metodológicas de que uma alta confiança dos contribuintes no Governo tem como resultado mais observância fiscal voluntária e que a alta percepção do poder das autoridades fiscais, por parte dos contribuintes, tem como resultado mais observância fiscal forçada.

Dessa forma, com base nos resultados, e respondendo a primeira questão de pesquisa, é possível afirmar que a interação de contribuintes, autoridades e Governo é significativa em termos de observância tributária, sendo que, na presença de um ambiente em que prevalece um clima de confiança na interação desses atores haverá, como consequência, uma maior observância fiscal voluntária, ao passo que a maior percepção do poder das autoridades por 
parte dos contribuintes, afeta suas atitudes, de modo que eles passam o obedecer à lei de forma forçada, ou seja, em resposta ao exercício da coerção legal, caracterizando, assim, a observância forçada.

Importante destacar que os resultados confirmam a limitação do paradigma econômico clássico que pressupõe a racionalidade do contribuinte, na medida em que sugere que o contribuinte, na presença de um ambiente cooperativo e, havendo confiança nas autoridades e no Governo, obedecerá a lei de forma voluntária ao invés de buscar maximizar sua utilidade. Há outros fatores, portanto, que influenciam o comportamento do contribuinte que não apenas seu desejo de maximização econômica.

Adicionalmente, os resultados demonstraram que as variáveis confiança e poder afetam o nível de arrecadação de impostos, sendo que em países que apresentem características de baixa confiança no Governo e pouca percepção de poder das autoridades haverá mais evasão fiscal.

Destaque-se, no entanto, que, ao contrário do que pressupõe o Slippery Slope Framework, não houve qualquer efeito estatisticamente significante na análise da interação de poder e força.

Por fim, observa-se que a variável idade do contribuinte é relevante para os níveis de observância fiscal, seja ela voluntária ou forçada. Quanto maior a idade do indivíduo, mais altos os níveis de observância, o que está de acordo com o previsto e verificado por outros pesquisadores, conforme citado no tópico 2.1.2.

Os resultados corroboram também as questões discutidas no Capítulo 2 - Referencial teórico, ao demonstrar, empiricamente, que a confiança é vetor de observância voluntária, enquanto o poder é vetor de observância forçada, confirmando os pressupostos do Slippery Slope Framework. Ademais, os resultados confirmam que tanto o "paradigma do serviço" 
quanto o "paradigma do crime" possuem ferramentas que induzem maior observância fiscal, possibilitando que as autoridades as manejem de forma mais eficiente, integrando ambos os paradigmas conforme as estratégias de alocação de custos e atingindo uma quantidade maior de contribuintes, em linha com o que foi discutido especificamente no tópico 2.1.3.

\subsection{Do experimento}

Essa etapa analisa os resultados do experimento com a finalidade de responder a segunda questão de pesquisa, do tópico 1.4 , testando a hipótese $H_{3}$, citada no tópico 1.5 . Isso será possível através da avaliação do montante pago de tributos pelos participantes em cada um dos grupos experimentais, com posterior comparação dos resultados dentro dos grupos e entre eles. Reitera-se que o Apêndice D contém detalhes das etapas do procedimento.

\subsubsection{Da metodologia estatística}

Inicialmente primordial declinar que o delineamento experimental possibilitou a realização de testes estatísticos, com a apresentação de resultados robustos. Isso porque foram realizados testes comparando os grupos com intervenções e o grupo controle (linha de base), possibilitando verificar a existência de diferenças estatisticamente significantes entre os grupos. Há, porém, algumas críticas em relação a esse procedimento, na medida em que o sujeito é considerado uma das maiores fontes de variabilidade em uma pesquisa, segundo Moreira e Hanna (2012). Vale dizer que a variabilidade entre os sujeitos pode afetar o controle de todas as variáveis que, virtualmente, afetam suas decisões.

Ciente disso, e apesar de a randomização dos grupos ser técnica eficiente para controle das variáveis, como discutido antes, ao mesmo tempo foram realizados testes dentro do próprio grupo, comparando-se o participante com ele mesmo, antes e depois do tratamento experimental, ou, como chamado pela Análise do Comportamento, utilizou-se o delineamento 
de sujeito único (Andery, 2010), também denominado delineamento de sujeito servindo como seu próprio controle (Moreira \& Hanna, 2012).

A vantagem desse método de avaliação é que há uma comparação do mesmo sujeito, antes e depois da manipulação do ambiente. Como resultado, grande parte das variáveis que poderiam influenciar o resultado é controlada (Moreira \& Hanna, 2012). Isso não ocorre, por exemplo, quando se comparam grupos com sujeitos diversos, pois há variabilidade entre os sujeitos, decorrentes de sua própria história, concepções e interações ao longo da vida que podem interferir no resultado (Moreira \& Hanna, 2012), embora, repita-se, a randomização seja considerada técnica adequada para resolver esse problema. Kantowitz, Roediger e Elmes (2009) lecionam que na comparação dentro do grupo, qualquer diferença nos resultados antes e depois da aplicação do tratamento experimental não pode ser atribuída às possíveis diferenças entre seus participantes, o que reforça os resultados.

Diante disso, a confrontação dos resultados dentro e entre os grupos fornece conclusões consideravelmente robustas. Porém, antes de adentrar nos resultados, necessário mencionar, brevemente, sobre as técnicas estatísticas que serão utilizadas na análise, limitando-se àquelas ainda não abordadas neste estudo.

Para responder aos objetivos do estudo, além da análise exploratória de dados (frequências absoluta e relativa), foram utilizados o teste T-Student, o teste não paramétrico de Sinais (análogo ao teste T), a Anova com comparações múltiplas de Tukey, o teste não paramétrico de Kruskal-Wallis (análogo à Anova) e as comparações múltiplas não paramétricas de Dunn (análogas ao teste de Tukey).

O teste T de Student foi utilizado para comparar as médias de imposto pago dentro do grupo, antes de depois do tratamento experimental, na medida em que ele possibilita a comparação de dados pareados, analisando se a média inicial do grupo é estatisticamente equivalente à média final. Levando-se em conta que a suposição de normalidade do teste não 
foi verificada, optou-se pelo emprego do teste de Sinais para confirmação dos resultados. Segundo Martins e Domingues (2011), o teste de Sinais é uma técnica não paramétrica utilizada para análise de dados emparelhados, quando o pesquisador pretende avaliar se duas condições são estatisticamente diferentes.

Todos os testes de hipóteses desenvolvidos neste estudo consideraram uma significância de 5\%; isto é, a hipótese nula foi rejeitada quando $p$-valor foi inferior a 0,05.

\subsubsection{Da apresentação dos resultados}

Convém iniciar a análise com uma breve descrição da amostra quanto à quantidade de respondentes em cada grupo de tratamento e sexo. Em relação à escolaridade, como esclarecido no tópico 3.2.2, todos os respondentes foram alunos de MBA ou cursavam uma segunda graduação.

Verifica-se que o número de observações por grupo de tratamento é totalmente equilibrado, sendo 49 indivíduos por grupo, totalizando 147. Em relação ao tamanho da amostra, atingiu-se número que, embora não permita generalizações, mostra-se perfeitamente aceitável quando comparado com outros estudos experimentais sobre observância fiscal (Friedland, Maital, \& Rutenberg, 1978; Mittone, 2006; Spicer \& Becker, 1980). Considerando as dificuldades enfrentadas na obtenção da amostra, fato típico em estudos experimentais com a presença do pesquisador, entende-se que o montante atingido é plenamente admissível.

Quanto ao gênero, observou-se que $56 \%$ da amostra pertence ao sexo masculino e $44 \%$ ao sexo feminino. Na Tabela 18, verifica-se a distribuição dos participantes nos grupos e nos gêneros. 
Tabela 18 - Distribuição da amostra quanto ao grupo de tratamento e sexo

\begin{tabular}{clcc}
\hline \multirow{2}{*}{ Variável } & Categoria & \multicolumn{2}{c}{ Amostra completa } \\
& & & \\
\cline { 3 - 4 } & & $\mathrm{N}^{\circ}$ de observações & Proporção (\%) \\
\hline \multirow{2}{*}{ Grupo } & Grupo Controle & 49 & 33,3 \\
& Grupo Punições & 49 & 33,3 \\
& Grupo Recompensas & 49 & 33,3 \\
\hline \multirow{2}{*}{ Sexo } & Feminino & 65 & 44,0 \\
& Masculino & 82 & 56,0 \\
\hline \multirow{2}{*}{} & Total & 147 & 100,0 \\
\hline
\end{tabular}

Fonte: Elaborada pelo autor.

Avaliando-se o pagamento de imposto médio ao longo do tempo, verifica-se uma tendência constante de diminuição de pagamento no grupo controle. No grupo punições, observa-se uma tendência de aumento até o 4 o período, seguido de queda até o 70 período, e, então, de aumento até o 10 período. Para o grupo recompensas, após um aumento do 1ำ para o 2ำ período, registra-se certa constância de pagamento até o 7으 período, seguindo-se, a partir de então, uma tendência de aumento até o 9o período.

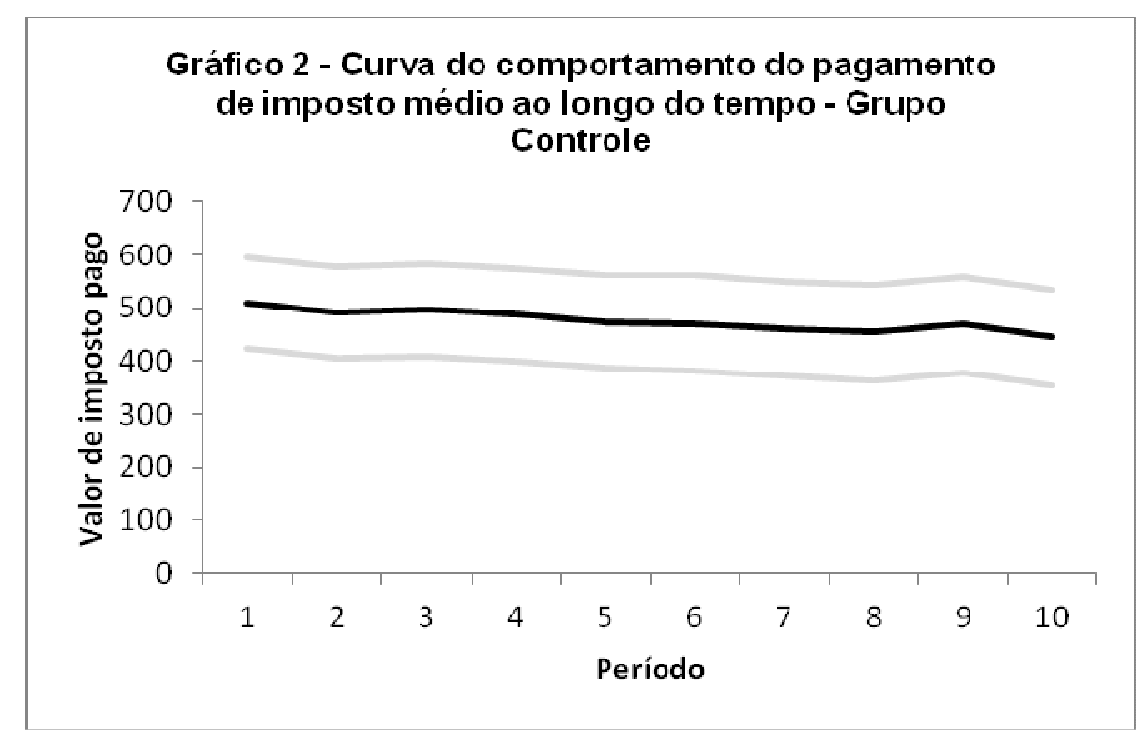

Fonte: Elaborado pelo autor. 


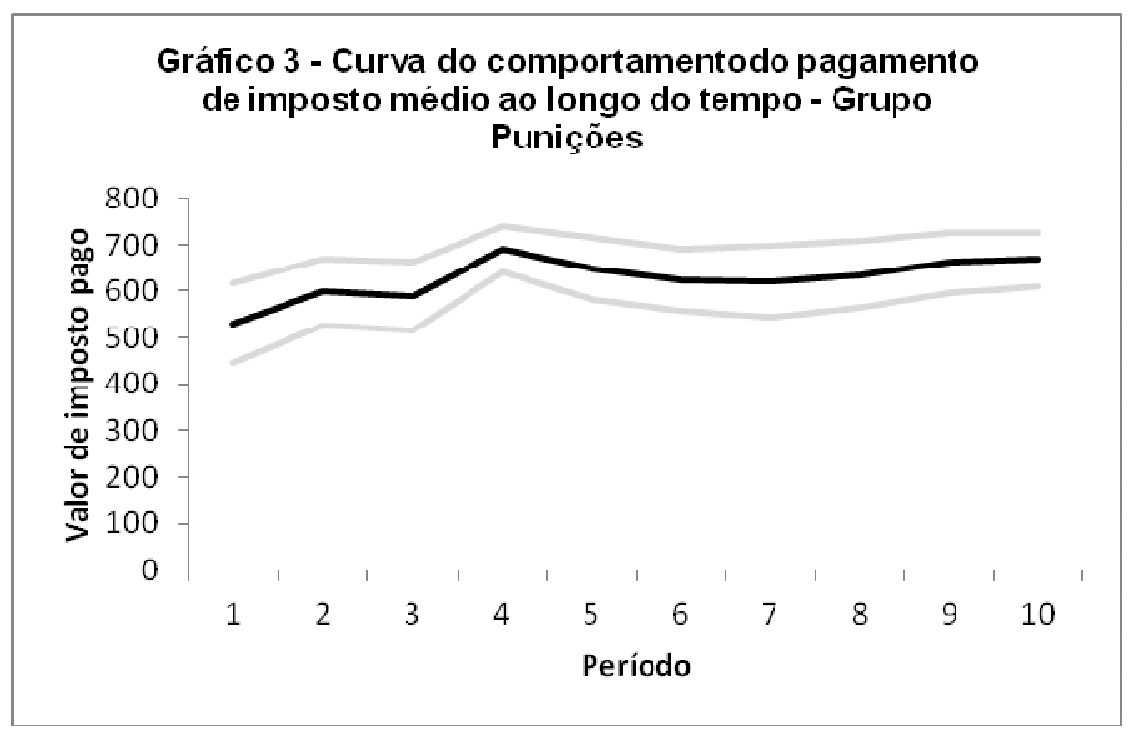

Fonte: Elaborado pelo autor.

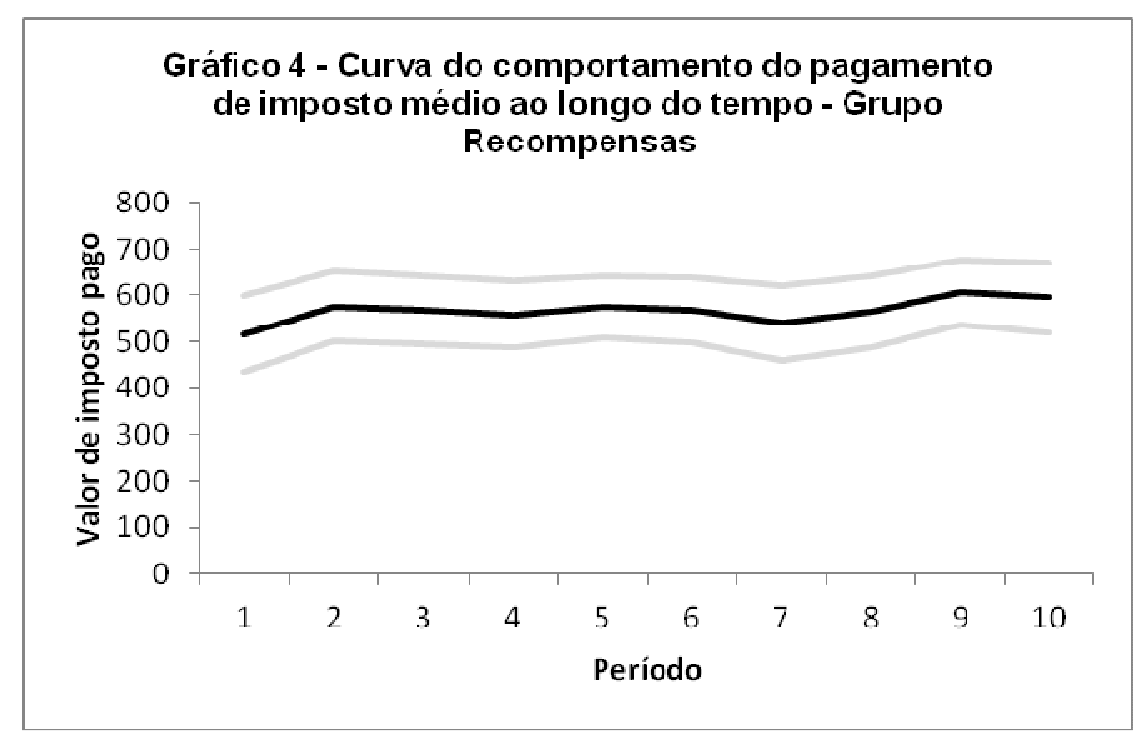

Fonte: Elaborado pelo autor.

A Tabela 19 mostra os valores médios do imposto pago nos períodos 1 e 10 para cada um dos grupos de tratamento, a diferença entre os momentos anterior e posterior (diferença = depois - antes) e o resultado dos testes estatísticos. É possível verificar em valores absolutos a redução da quantia paga no grupo controle e o aumento nos grupos punições e recompensas, por meio da comparação do período 10 com o 1. 
Tabela 19 - Efeito do tratamento para cada grupo

\begin{tabular}{lccccccc}
\hline \multirow{2}{*}{ Grupo } & \multicolumn{3}{c}{ Média } & & \multicolumn{2}{c}{ p-valor } \\
\cline { 2 - 5 } & Período & Período & Diferença & & Teste T & Teste de \\
(período & $10-$ período 1) & & Sinais \\
\hline Grupo Controle & 1 & 10 & 445 & -64 & 0,0073 & 0,0035 \\
Grupo Punições & 509 & 531 & 669 & 138 & & 0,0023 & 0,0012 \\
Grupo Recompensas & 517 & 595 & 78 & & 0,0222 & 0,0234 \\
\hline
\end{tabular}

Fonte: Elaborada pelo autor.

O Gráfico 5 reproduz essa tabela, demonstrando a evolução da arrecadação média, ao mesmo tempo comparando o início (antes do tratamento) com o resultado final (após o tratamento).

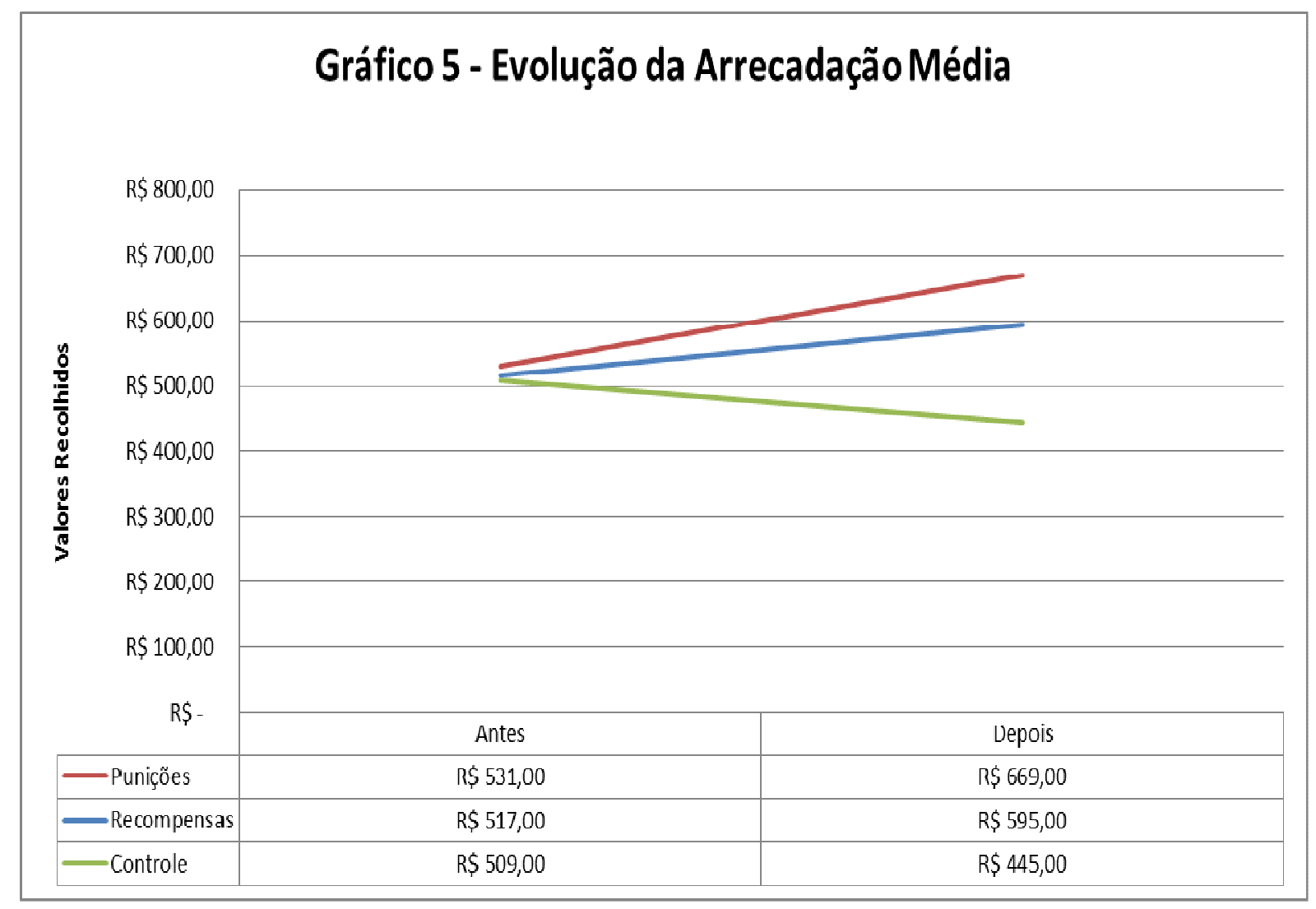

Gráfico 5 - Evolução da arrecadação média

Fonte: Elaborado pelo autor. 
O teste $\mathrm{T}$ para a comparação entre o antes e o depois de cada grupo apresenta significância do efeito do tratamento em todos os grupos, inclusive no grupo controle. $\mathrm{Na}$ Tabela 19, pode-se observar que no grupo controle houve uma diminuição no pagamento de impostos no período, ao passo que nos grupos "punições" e "recompensas" houve um aumento, sendo o grupo "punições" o que mais cresceu.

Embora a suposição de normalidade do teste $T$ não foi atingida, observou-se que os resultados do teste não paramétrico dos Sinais corroboram os resultados encontrados no teste de T, como mostra a Tabela 19.

Posteriormente, foram desenvolvidos três modelos de Anova, considerando como fatores as variáveis grupo de tratamento e sexo, sendo um modelo para a comparação do imposto pago no período 1 entre os grupos, um para a comparação dos grupos no momento 10 e o outro para a comparação do impacto do tratamento entre os grupos (variável de diferença $=$ depois - antes).

Observa-se que para o período 1 não houve diferença entre os grupos ( $p$-valor = 0.9312), mas houve diferença significativa entre os gêneros ( $p$-valor $=0.0291$ ). Já no período 10 , observa-se o efeito dos grupos $(p$-valor $=0.0002)$. Através do teste de Tukey, verifica-se que ocorre uma diferença entre o grupo controle e os grupos punições e recompensas, sendo que o grupo controle apresentou diminuição no pagamento, enquanto nos outros dois houve aumento.

\begin{tabular}{cccc}
\hline \hline $\begin{array}{l}\text { Tabela } 20 \text { - Comparação entre os grupos no momento anterior ao } \\
\text { tratamento }\end{array}$ & & \\
\hline Efeito & GL & Estatística F & p-valor \\
\hline Grupo & 2 & 0,07 & 0,9312 \\
Sexo & 1 & 4,86 & 0,0291 \\
\hline
\end{tabular}

Fonte: Elaborada pelo autor. 


\begin{tabular}{cccc}
\hline \hline Tabela 21 - Comparação entre grupos no momento posterior ao \\
tratamento \\
& & & \\
\hline Efeito & GL & Estatística $\mathrm{F}$ & $\mathrm{p}$-valor \\
\hline Grupo & 2 & 9,25 & 0,0002 \\
Sexo & 1 & 0,55 & 0,4592 \\
\hline
\end{tabular}

Fonte: Elaborada pelo autor.

\begin{tabular}{ccc}
\hline \hline $\begin{array}{c}\text { Tabela } 22 \text { - Comparações multiplas de Tukey para diferença } \\
\text { entre os grupos no momento posterior ao tratamento }\end{array}$ \\
\hline Comparação & Grupo Controle & $\begin{array}{c}\text { Grupo Estímulo } \\
\text { Punitivo }\end{array}$ \\
\hline Grupo Punições & 0,0001 & 0,3551 \\
Grupo Reforços & 0,0142 & 0,351 \\
\hline
\end{tabular}

Fonte: Elaborada pelo autor.

Comparando os impactos dos tratamentos observamos diferenças significativas entre os grupos ( $p$-valor $=0.0001)$, sendo que a diferença se deu entre o grupo controle e o grupo punições $(p$-valor $=0.0001)$ e entre o grupo controle e o grupo recompensas $(p$-valor $=0.0099)$. Não houve diferença significativa entre o grupo de tratamento "punições" e "recompensas" (pvalor $=0.4107$ ).

\begin{tabular}{cccc}
\hline \hline $\begin{array}{c}\text { Tabela 23 - Análise de variância para diferença entre os grupos no } \\
\text { efeito do tratamento }\end{array}$ & & \\
\hline Efeito & GL & Estatística F & p-valor \\
\hline Grupo & 2 & 9,47 & 0,0001 \\
Sexo & 1 & 3,5 & 0,0633 \\
\hline
\end{tabular}

Fonte: Elaborada pelo autor.

\begin{tabular}{ccc}
\hline \hline $\begin{array}{c}\text { Tabela } 24 \text { - Comparações multiplas de Tukey para diferença } \\
\text { entre os grupos na diferença de pagamento de importo entre } \\
\text { os momentos anterior e posterior (depois - antes) }\end{array}$ \\
\hline Comparação & Grupo Controle & $\begin{array}{c}\text { Grupo Estímulo } \\
\text { Punitivo }\end{array}$ \\
\hline Grupo Punições & 0,0001 & 0,4107 \\
\hline
\end{tabular}

Fonte: Elaborada pelo autor. 
Com relação às suposições dos modelos, observou-se, via análise gráfica, que o modelo Anova para os períodos 1 e 10 registra maior afastamento da normalidade, mas apresenta homoscedasticidade. Já o modelo das diferenças apresentou normalidade, mas afastamento da homoscedasticidade. Dessa maneira, foi aplicado o teste não paramétrico de Kruskal-Wallis com comparações múltiplas de Dunn.

Observou-se que os resultados da análise não paramétrica do teste de Kruskal-Wallis são bastante similares aos da análise paramétrica. No período 1 não foi detectada diferença entre os grupos de tratamento ( $p$-valor $=0.8928$ ). Já no período 10 foi detectado efeito do tratamento ( $p$-valor $=0.0013$ ), sendo que a diferença foi detectada entre o grupo controle e os grupos punições e recompensas. Com relação à diferença entre o antes e o depois dos grupos, também se observou significância dos grupos de tratamento ( $p$-valor $=0.0004)$, sendo que a diferença foi detectada entre os grupos punições e recompensas em comparação com o grupo controle.

\begin{tabular}{lc}
\hline \hline $\begin{array}{r}\text { Tabela 25 - Teste de Kruskal-Wallis para comparação } \\
\text { entre os três grupos de tratamento }\end{array}$ \\
\hline \multicolumn{1}{c}{ Modelo } & p-valor \\
\hline Período 1 & 0,8928 \\
Período 10 & 0,0013 \\
Diferença (período 10 - período 1) & 0,0004 \\
\hline
\end{tabular}

Fonte: Elaborada pelo autor.

\begin{tabular}{ccc}
\hline \hline $\begin{array}{c}\text { Tabela } 26 \text { - Comparações multiplas de Dunn para diferença entre os grupos no } \\
\text { momento anterior e posterior (depois-antes) }\end{array}$ & $\begin{array}{c}\text { Grupo Estímulo } \\
\text { Punitivo }\end{array}$ \\
\hline Comparação & Grupo Controle & 0,8070 \\
\hline Grupo Punições & 0,0000 & 0,0200 \\
Grupo Recompensas & 0,800
\end{tabular}

Fonte: Elaborada pelo autor. 


\begin{tabular}{ccc}
\hline \hline $\begin{array}{c}\text { Tabela } 27 \text { - Comparações multiplas de Dunn para diferença entre os grupos na } \\
\text { diferença de pagamento de importo entre os momentos anterior e posterior } \\
\text { (depois - antes) }\end{array}$ \\
\hline Comparação & Grupo Controle & $\begin{array}{c}\text { Grupo Estímulo } \\
\text { Punitivo }\end{array}$ \\
\hline Grupo Punições & 0,0010 & \\
Grupo Recompensas & 0,0500 & 0,7130 \\
\hline
\end{tabular}

Fonte: Elaborada pelo autor.

\subsubsection{Analisando os resultados do experimento}

Os resultados dos testes estatísticos apresentados no tópico precedente possibilitam responder a segunda questão de pesquisa. Os testes confirmaram a hipótese $\mathbf{H}_{3}$ : $\mathrm{A}$ implementação de políticas públicas baseadas em punições e recompensas gera mais conformidade fiscal.

Efetivamente, restou demonstrado que o emprego de punições e recompensas efetivas e potenciais gera mais conformidade fiscal, aumentando o nível de arrecadação tributária em ambos os grupos. O resultado é confirmado pela queda no nível de recolhimento tributário no grupo controle, no qual não se implementou nenhuma prática visando incentivar ou punir o comportamento do contribuinte.

Destaque-se que o aumento da conformidade tributária no grupo punições está em conformidade com o resultado de outras pesquisas que demonstram que a realização de auditorias tem como consequência os efeitos observados neste estudo (Dubin, Jeffrey, Graetz, \& Wilde, 1990; Dubin \& Wilde, 1988; Plumley, 1996), inclusive aquelas que utilizaram metodologia experimental (Spicer \& Rodney, 1985; Webley, 1987).

Ressalte-se o experimento conduzido por Kastlunger et al. (2009), os quais constataram que a realização de auditorias influencia o nível de observância fiscal, embora ressaltem que esse efeito depende do momento em que são realizadas. Vale dizer que quando o contribuinte 
é confrontado com uma auditoria no início de sua experiência fiscal, ocorre um aumento da observância, ao contrário do que se verifica quando tais procedimentos são implementados tardiamente, resultado também verificado por Mittone (2006). Como no experimento objeto desta dissertação o procedimento de fiscalização no grupo punições ocorria logo no segundo período, é seguro dizer que os resultados são semelhantes.

Oportuno ressaltar, porém, a existência de pesquisas segundo as quais as auditorias influenciam o comportamento dos contribuintes, embora sugiram que tais efeitos foram pouco efetivos (Erard, 1992). Nessa linha, Andreoni, Erard e Feinstein (1998) aduzem que talvez o resultado das fiscalizações nem sempre é tão desastroso quanto previam os contribuintes, não influenciando seu comportamento futuro, ao menos no que diz respeito a mais observância fiscal. Por outro lado, Kirchler et al. (2010), após avaliar diversas pesquisas, concluíram que auditorias e punições tem um efeito leve, porém evidente, em termos de observância fiscal.

Há que se destacar, contudo, que no caso do presente estudo os participantes do grupo punição sempre eram fiscalizados e, consequentemente, punidos em caso de evasão fiscal. Portanto, os resultados sugerem, considerando o aumento no nível de observância, que a realização de auditorias com a efetiva punição do contribuinte influencia seu comportamento, resultando em mais conformidade fiscal. Evidentemente há a ressalva de que no mundo real nem sempre o procedimento de fiscalização resulta em punições, como pontuado no paragráfo anterior.

Em relação à dicotomia "punições e recompensas", é oportuno citar que, através de estudo experimental, Andreoni, Harbaugh e Vesterlund (2003) verificaram que as punições tiveram influência superior na cooperação fiscal, quando comparadas com as recompensas. Os autores, ao contrário do que foi realizado neste estudo, deram um passo adiante ao introduzir um grupo experimental combinando recompensas e punições, cujo resultado demonstrou uma forte influência nos níveis de cooperação fiscal, o que os levaram a concluir que recompensas e 
punições são complementares e devem estar presentes no sistema fiscal em conjunto, em linha com o que foi defendido neste estudo, em especial no tópico 2.3.

Torgler (2003a), ao seu turno, verificou que o grupo experimental cujos participantes recebiam incentivos positivos apresentou alta taxa de observância fiscal, embora nesse caso não tenha havido comparação com o emprego de punições. Resultado semelhante foi obtido por Alm, Jackson e McKee (1992a).

Bazart e Pickhardt (2011) igualmente conduziram estudo experimental, por meio do qual constataram que as recompensas através da participação de contribuintes adimplentes em sorteios produzem um forte impacto positivo sobre o cumprimento das obrigações fiscais. Os autores acrescentam que a introdução desse tipo de estratégia nos países em desenvolvimento, como é o caso do Brasil, é um caminho promissor.

Resultados contrários, contudo, foram verificados por Kastlunger et al. (2011). Nesse estudo experimental os autores verificaram que as recompensas não ocasionaram um aumento da receita tributária. Há que se destacar, porém, que o design experimental nessa pesquisa preconizava a comparação de um grupo experimental prevendo apenas punição, com outro cujos participantes se deparavam com punições reduzidas e recompensas, de modo que o resultado pode ter sido consequência da redução do peso das punições, e não necessariamente indicam que as recompensas não teriam influenciado a observância fiscal.

Em relação ao grupo controle, em que sucessivas etapas não resultam em qualquer punição, é fundamentar registrar que a diminuição do nível de arrecadação confirma proposição teórica segundo a qual o contribuinte paga tributos quando suspeita que poderá ser detectado, mas sonega tão logo percebe que essa possibilidade é reduzida. Conforme demonstraram Kastlunger et al. (2009), a observância fiscal reduz na medida em que os participantes não são auditados por um longo período, exatamente como foi o caso do grupo controle aqui estudado. 
De se ressaltar, por oportuno, que os resultados são bastante robustos, na medida em que foram realizados testes comparativos, sendo notada diferença estatisticamente significante entre os grupos de tratamento experimental e o grupo controle. Ademais, não obstante a randomização tornar dispensável a comparação dentro dos grupos, a fim de garantir mais confiabilidade aos resultados, foram realizados testes que demonstram que punições e recompensas geraram mais conformidade dentro dos grupos, aumentando o nível de arrecadação, o que não ocorreu no grupo controle.

Tais resultados possibilitam confirmar a hipótese metodológica de que a implementação de políticas públicas baseadas em punições e recompensas gera mais conformidade fiscal.

Dessa forma, e com base nos resultados e respondendo a segunda questão de pesquisa, pode-se afirmar que por meio da utilização tanto de punições, como também de recompensas efetivas e potenciais, é possível influenciar o comportamento do contribuinte, obtendo-se como principal consequência mais conformidade fiscal. Isso proporciona às autoridades uma gama maior de ferramentas visando ao combate à sonegação fiscal, que não apenas a adoção de punições, muito embora essas práticas também tenham se mostrado eficientes. Além disso, restou demonstrado que a observância fiscal depende do manejo de ferramentas nesse sentido, eis que quando os contribuintes não foram incentivados a tanto, seja através de punições ou de recompensas, como ocorreu no grupo controle, caiu o nível de arrecadação.

Embora não fosse essa a intenção, é interessante notar que os resultados do experimento reforçam os resultados da pesquisa on-line no sentido de que há outras formar de influenciar a observância tributária que não apenas a aplicação de punições em busca da observância fiscal forçada. Os resultados indicam que a integração é o caminho, inclusive na busca de mais observância voluntária, conforme explanado no item 2.3. Igualmente, a utilização de recompensas pode minimizar os efeitos deletérios do emprego de punições excessivas, o que também foi abordado no tópico 2.2.2 deste estudo. 
Os resultados, ademais, corroboram as questões discutidas no Capítulo 2 - Referencial teórico, ao demonstrar, empiricamente, que o comportamento do contribuinte pode ser influenciado utilizando-se as técnicas ensinadas pela Análise do Comportamento. Necessário ressalvar, contudo, que, conforme discutido, práticas aversivas geram efeitos colaterais indesejados. De toda forma, não parece ser possível, ao menos considerando-se o contexto social atual, um sistema tributário sem a previsão de punições para os infratores. Promissora, no entanto, a demonstração de que práticas não aversivas, como o oferecimento de recompensas, também geram mais conformidade fiscal, o que incentiva a adoção de novas iniciativas nesse sentido. 


\section{CONSIDERAÇÕES FINAIS}

\subsection{Conclusões}

Embora não seja usual, devido à vastidão de conceitos discutidos ao longo do presente estudo, as conclusões são apresentadas de forma pontual e linear, resumindo e facilitando a compreensão dos diversos aspectos e temas envolvidos na pesquisa. Dessa forma, são assim resumidos os pontos abordados, achados e conclusões, com base na fundamentação teórica e resultados empíricos:

- o paradigma econômico clássico pressupõe que o ser humano é racional, adotando decisões utilitaristas, sempre procurando maximizar seu retorno;

- do paradigma econômico clássico deriva o "paradigma do crime";

- segundo o "paradigma do crime", o receio de ser punido afeta positivamente a observância fiscal dos contribuintes racionais;

- a denominação "paradigma do crime" advém justamente do fato de as autoridades empreenderem uma espécie de busca de transgressores da lei, a fim de puni-los, como se fossem criminosos;

- o "paradigma do crime" pressupõe que para combater a evasão fiscal, as autoridades dispõem de ferramentas como a severidade da punição e o aumento da probabilidade de detecção, o que, por sua vez, faz aumentar a observância fiscal forçada;

- o aumento da probabilidade de detecção é mais efetivo do que a severidade da punição, embora a constante presença de fiscais na vida dos cidadãos tenha como consequência a prática de contracontrole;

- o aumento da probabilidade de detecção exige altos investimentos governamentais, impondo dilemas de escolha, ou seja, trade-offs;

- as autoridades tendem a optar pela imposição de penas mais severas, que não exigem tantos investimentos, ao contrário do que ocorre com o aumento da probabilidade de detecção; 
- o agravamento das penas sem o aumento da probabilidade de detecção prejudica seriamente a percepção de justiça fiscal, na medida em que poucos contribuintes são punidos e de forma excessiva;

- nem todos os contribuintes agem de forma racional, o que equivale a dizer que o "paradigma do crime" é limitado;

- segundo o "paradigma do serviço", outras motivações levam o contribuinte a obedecer à legislação tributária, destacando-se, dentre elas, a percepção de justiça fiscal;

- o "paradigma do serviço" pressupõe que o tratamento do contribuinte como uma espécie de cliente da administração pública gera um clima de confiança e cooperação, aumentando a arrecadação tributária através da observância voluntária;

- o alcance de um nível adequado de confiança e observância voluntária também pressupõe altos investimentos no longo prazo, o que igualmente acarreta custos e dilemas de escolhas para o Governo;

- considerando-se esses dilemas e que não é razoável supor que todos os contribuintes possuem motivações semelhantes, não sendo um grupo homogêneo, havendo indivíduos racionais e outros mais suscetíveis a reagir de acordo com a percepção de justiça fiscal, moral, ética, norma social etc., o caminho mais promissor para o combate da evasão fiscal parece ser a integração dos paradigmas "do crime" e "do serviço", de modo a se atingir os contribuintes de forma mais abrangente;

- a integração dos dois paradigmas ainda pode proporcionar uma melhor alocação de recursos, já que o aumento da observância voluntária possibilitaria que as autoridades passassem a direcionar seus esforços de detecção aos contribuintes mais propensos a agir racionalmente, os quais seriam obrigados a cumprir suas obrigações, ou seja, imposição coercitiva de observância fiscal;

- a despeito da integração dos dois paradigmas, as autoridades podem, concomitantemente, adotar de forma mais apropriada os ensinamentos de Skinner, utilizando as consequências como aprendizado do contribuinte, impondo de forma uniforme e sistemática consequências positivas para os indivíduos que cumprem suas 
obrigações fiscais e consequências negativas para aqueles que as descumprem, fazendo isso através de recompensas e punições, respectivamente;

- os resultados empíricos sustentam essas conclusões teóricas ao demonstrarem que a percepção do poder das autoridades pelos contribuintes afeta a observância fiscal forçada (paradigma do crime), enquanto, de outro lado, o nível de confiança dos contribuintes nas autoridades afeta a observância fiscal voluntária (paradigma do serviço). Além disso, os resultados demonstram ser possível combater a sonegação fiscal através do emprego de punições e recompensas, sugerindo que os princípios da Análise do Comportamento se integram com os dois paradigmas;

- há que se ressalvar que o controle aversivo produz diversos efeitos colaterais, estudados no decorrer do presente estudo. Parece ingênuo, contudo, imaginar um sistema legal tributário sem que certo nível de controle aversivo esteja presente, na medida em que o não pagamento de tributos tem como consequência imediata 0 reforço em razão da manutenção do dinheiro correspondente ao tributo. Nesse sentido, Sidman (1989/2009), com sua precisão habitual, esclarece: "Uma vez que as pessoas podem ganhar mais dinheiro, poder e prestígio violando a lei - sem serem presas - do que permanecendo dentre dela, um sistema legal sem punição continuará impraticável" (p. 266),

- os resultados demonstram, portanto, que não há paradigma único ou equivocado. Não se pode tratar a questão de forma maniqueísta, pois, dependendo do contexto, tanto o "paradigma do crime" como o "paradigma do serviço" será adequado para combater a sonegação fiscal, sendo a "pedra de toque" discernir de que forma as autoridades devem utilizar as ferramentas propostas por ambos os paradigmas, o que passa por uma rigorosa análise de alocação de recursos e o pleno conhecimento dos efeitos positivos e deletérios de cada alternativa;

- assim, o contribuinte deveria ser tratado como uma espécie de cliente da administração pública, sendo, porém, punido quando houver desvio de conduta. Recompensar aquele que cumpre suas obrigações também é uma prática efetiva e recomendada. Para tanto, os sinais devem ser claros e unívocos. Tais práticas não podem ser contraditórias. De 
nada adianta o contribuinte ser punido quando sonegar impostos e posteriormente ser perdoado, apenas para citar um exemplo. Esse tipo de política fiscal emite sinais controversos para os cidadãos, até mesmo fazendo desaparecer a consequência desagradável imposta em razão de sua atitude, o que acaba por sinalizar que a conduta correta é justamente o contrário, ou seja, a inadimplência fiscal;

- tudo isso posto, é firme a conclusão de que há ferramentas adequadas para combater a evasão fiscal, bastando uma análise mais criteriosa por parte das autoridades para a obtenção de mais arrecadação tributária. Isso passa necessariamente pela integração dos paradigmas "do crime" e "do serviço", bem como pelo conhecimento mais adequado dos princípios da Análise do Comportamento, utilizando-se com sabedoria os inestimáveis ensinamentos científicos de Skinner. Nesse sentido, a inserção de profissionais dessa ciência na avaliação das práticas das autoridades fiscais e na discussão sobre as leis tributárias tende a ser muito produtiva. Como bem pontuou Sidman (1989/2009): "Qualquer estadista, qualquer professor, qualquer empresário, qualquer funcionário e qualquer um que executa a lei deveria analisar a situação comportamentalmente (ou deveriam mandar fazer esta análise) em busca de alternativas" (p. 247); e

- isso passa pelo compromisso dos agentes políticos. As políticas tributárias devem ser pensadas em longo prazo e aplicadas tão-somente depois de avaliadas as consequências de sua adoção no comportamento dos contribuintes. Focar as políticas tributárias em apenas alguns grupos de interesse ou na arrecadação de curto prazo apenas condena o país a continuar vivendo um verdadeiro "carnaval tributário", expressão cunhada e imortalizada por Becker (1999).

\subsection{Limitações da pesquisa e futuros estudos}

O presente estudo objetivou aumentar a compreensão dos fatores que envolvem a observância tributária e de como diferentes tipos de abordagem afetam o comportamento do 
contribuinte, fornecendo novos insights que possibilitem um debate mais abrangente sobre a política fiscal, procurando compreender, ao menos em parte, tema tão complexo.

Considerando-se essa complexidade, as conclusões apresentadas devem ser avaliadas com cautela. Em primeiro lugar, não se pode inferir que os resultados esgotam o tema, que, por envolver o comportamento humano, merecem mais e novos estudos que confirmem ou infirmem aqueles apresentados nesta pesquisa. Cozby (2003) defende que as explicações do comportamento humano devem ser frequentemente descartadas ou revisadas, em razão de novas evidências. $\mathrm{O}$ autor ressalva que esse processo é motivo de satisfação e entusiasmo ao se fazer ciência.

Em raciocínio similar, Skinner (1953/2003) afirmava ser a ciência um processo dinâmico e de acumulação de conhecimentos. Dessa forma, cada geração de cientistas agrega conhecimento aos assuntos dantes estudados, trazendo mais precisão ao tema objeto de análise. Cabe aos demais e futuros pesquisadores repetir, criticar, analisar resultados, agregando mais conhecimento ou mesmo infirmando conclusões.

A propósito da metodologia empregada no presente estudo, algumas críticas podem surgir acerca da validade dos dados, eis que o survey e o experimento utilizados seriam mera simplificação da realidade. Embora essa constatação seja em princípio irrefutável, conforme reconheceu Sidman (1989/2009) ao afirmar que "de início a ciência sempre supersimplifica" (p. 281), o próprio Skinner (1974/2006) ensina que a direção da ciência é exatamente esta: do simples ao complexo. O autor reconhece que não é possível predizer e controlar o comportamento humano na realidade com precisão laboratorial. Os desvios são comuns. Porém, os resultados experimentais servem de guia para interpretação dos comportamentos do mundo real, sendo fundamental o seu estudo.

Nesse sentido, necessário reconhecer a dificuldade de realização de estudos empíricos envolvendo o tema observância tributária, fato esse reconhecido pelo meio acadêmico (Alm \& 
Torgler, 2011; Kirchler, 2007; Siqueira \& Ramos, 2005; Weigel et al., 1987). Esse cenário é ainda mais dramático no Brasil, especialmente em razão de um forte sigilo fiscal, que impede os pesquisadores de acessar dados que possam servir de base empírica para a realização de estudos acadêmicos ${ }^{23}$. No presente estudo, foi possível verificar que através da utilização de procedimentos metodológicos alternativos é possível coletar dados robustos que colaborem para a compreensão de temas relacionados ao campo fiscal, ainda que presentes todas as ressalvas, especialmente em relação aos possíveis vieses nas respostas dos participantes da survey e do experimento.

Ademais, é preciso assumir honestamente essas deficiências e dificuldades, não como um desincentivo à produção científica sobre o assunto ora em estudo, mas como um necessário esclarecimento do alcance de suas conclusões, que devem ser confirmadas por novas pesquisas, inclusive utilizando outros métodos de avaliação, em uma permanente produção de estudos que a cada dia forneçam mais certeza acerca dos resultados.

Recorre-se, aqui, às lições de Moreira e Hanna (2012), que enfatizam ser tarefa do cientista, especialmente no campo comportamental, descobrir cada vez mais as variáveis que afetam e influenciam a ocorrência de determinados eventos, como a evasão fiscal, e de que forma o Governo pode intervir e reduzir essa prática. Para descrever esse processo, os autores se valem de um didático exemplo, reproduzido a seguir:

Imagine, por exemplo, que um determinado fenômeno $\mathrm{X}$ ocorre sempre que os fenômenos A, B, C, D, E, F, G e H ocorrem conjuntamente. Imagine que este fenômeno seja chover e que $A$ seja "nuvens escuras no céu". Para que chova, é necessário A, B, C, D, E, F, G e H. Às vezes, você olha para o céu e verifica a presença de $A$, diz que vai chover e, logo depois, começa a chover. Embora você tenha observado apenas a variável $A$, as variáveis $B, C, D, E, F, G$ e $H$ estavam presentes, por isso

\footnotetext{
${ }^{23}$ A lei no 12.527 , de 18 de novembro de 2011, que regula o acesso à informação é iniciativa promissora e pode fomentar pesquisas no campo fiscal no país.
} 
choveu. Em outro momento, você verifica a presença de $A$, diz que vai chover, mas não chove. Provavelmente, neste caso, uma das demais variáveis não estava presente. Suponha que você aprenda a identificar a ocorrência de B (umidade do ar acima de $80 \%$, por exemplo). A partir desse momento, você só fará previsão de chuva se verificar a presença de A+B. Embora você ainda erre muitas vezes, pois não conhece - ou não é capaz de identificar - a presença das demais variáveis, você acertará mais vezes do que quando conhecia apenas a variável A; e a cada nova variável que você aprende a identificar, mais acurada fica sua previsão. É assim que o conhecimento científico progride (p. 16).

Essa sábia lição serve de incentivo para estudos futuros sobre o tema, seja reproduzindo a metodologia e o framework ${ }^{24}$ aqui empregados, ou mesmo através de metodologias diversas, incluindo a pesquisa archival, que podem reforçar as conclusões de estudos experimentais, como, inclusive, defendem (Weigel et al., 1987). Considerando-se que o tema ainda é pouco estudado no Brasil, há um campo fértil de pesquisa e um longo caminho até a melhor compreensão do comportamento do contribuinte brasileiro.

Em especial, sugere-se a repetição do estudo, por ser esse o principal meio de validação de resultados (Hair et al. 2006), seja utilizando participantes com características e localização semelhantes ou diversas, bem como aumentando-se a amostra, tornando os resultados ainda mais robustos. Pode ser sábio, na replicação da segunda parte deste estudo, a inclusão de um grupo experimental que contenha manipulação incluindo conjuntamente punições e recompensas, conforme procedido por Andreoni et al. (2003), proporcionando a avaliação dos efeitos da interação de ambas as formas de influenciar o aprendizado e o comportamento do contribuinte.

\footnotetext{
${ }^{24}$ Slippery Slope Framework.
} 
Profícuo, igualmente, é que as pesquisas sobre o comportamento do contribuinte e a observância tributária considerem não apenas o paradigma econômico clássico, mas também abordem elementos afetos a outras disciplinas, em especial a Psicologia, conforme sugerem Alm et al. (2012b), o que é raro de se observar no Brasil. Justo reconhecer que muito há a se aprender com os profissionais da Análise do Comportamento. De se lamentar que sua atuação algumas vezes fique restrita à aprendizagem básica, quando seu conhecimento é muito mais abrangente e poderia ser eficazmente utilizado na busca de uma sociedade mais justa, inclusive através de avaliação da adequação das leis e de suas potenciais consequências no seio social.

Nesse sentido, necessário que sejam aprofundados os temas relacionados à Análise do Comportamento abordados durante este estudo. As limitações, embora não invalidem os resultados, revelam a necessidade de se dar continuidade ao estudo do tema. Alguns pontos não discutidos, como, por exemplo, a questão da extinção operante, que se refere ao fato de a ausência de reforço causar a extinção do comportamento, a problemática dos esquemas de reforçamento, que sugerem que a apresentação de reforço intermitente é superior na manutenção de respostas anteriormente modeladas, ou mesmo a questão dos efeitos colateriais que o controle aversivo pode causar nos contribuintes, são apenas alguns dos pontos que merecem novas análises, as quais são fortemente recomendadas, em especial pelos profissionais que lidam diariamente com essa ciência.

Enfim, como, de forma brilhante, afirmou Skinner (1969/2013): "Não considere nenhuma prática como imutável. Mude e esteja pronto a mudar novamente. Não aceite verdade eterna. Experimente" (p. 2). É assim que se dá o processo científico, e esse foi o objetivo deste estudo! 


\section{REFERÊNCIAS}

Afonso, J. R. (2012). Keynes, crise e política fiscal. São Paulo: Saraiva.

Ahmed, E. (2005). Understanding small business taxpayers: issues of deterrence, tax morale, fairness and work practice. International Small Business Journal, 23(5), 539-568.

Allingham, M. G., \& Sandmo, A. (1972). Income tax evasion: a theoretical analysis. Journal of Public Economics, 1, 323-338.

Alm, J. (1991, July). A perspective on the experimental analysis of taxpayer reporting. The Accounting Review, 66(3), 577-593.

Alm, J. (2012). Measuring, explaining, and controlling tax evasion: lessons from theory, experiments, and field studies. International Tax and Public Finance, 19, 54-77.

Alm, J., Jackson, B., \& McKee, M. (1992a). Deterrence and beyond: toward a kinder, gentler IRS. In Slemrod J. (Ed.). Why people pay taxes. Ann Arbor: University of Michigan Press (pp. 311-329).

Alm, J., Kirchler, E., \& Müehlbacher, S. (2012a, September). Combining psychology and economics in the analysis of compliance: from enforcement to cooperation. Economic Analysis and Policy, 42(2), 133-151.

Alm, J., Kirchler, E., Müehlbacher, S., Gangl, K., Hofmann, E., Kogler, C., \& Pollai, M. (2012b). Rethinking the research paradigms for analyzing tax compliance behavior. CESifo Forum, 13(2), 33-40.

Alm, J., McClelland, G. H., \& Schulze, W. D. (1992b). Why do people pay taxes? Journal of Public Economics, 48(1), 21-38.

Alm, J., McClelland, G. H., \& Schulze, W. D. (1999). Changing the social norm of tax compliance by voting. Kyklos, 52, 141-171.

Alm, J., McKee, M., \& Beck, M. (1990). Amazing grace: tax amnesties and compliance. National Tax Journal, 43(1), 23-37.

Alm, J., Sanchez, I., \& Juan, A. (1995). Economic and noneconomic factors in tax compliance. Kyklos, 48, 3-18.

Alm, J., \& Torgler, B. (2006). Culture differences and tax morale in the United States and in Europe. Journal of Economic Psychology, 27, 224-246. 
Alm, J., \& Torgler, B. (2011). Do ethics matter? Tax compliance and morality. Journal of Business Ethics, 101, 635-651.

Andery, M. A. P. A. (2010, abril/junho). Métodos de pesquisa em análise do comportamento. Psicologia USP, 21(2), 313-342.

Andreoni, J., Erard, B., \& Feinstein, J. (1998, June). Tax compliance. Journal of Economic Literature, 36(2), 818-860.

Andreoni, J., Harbaugh, W., \& Vesterlund, L. (2003). The carrot or the stick: rewards, punishments, and cooperation. The American Economic Review, 93(3), 893-902.

Baer, D. M., Wolf, M. M., \& Risley, T. R. (1968). Some current dimensions of applied behavior analysis. Journal of Applied Behavior Analysis, 1(1), 91-97.

Bahl, R. W., \& Bird, R. M. (2008, June). Tax policy in developing countries: looking back and forward. National Tax Journal, 61(2), 279-301.

Baum, W. M. (2006). Compreender o behaviorismo: comportamento, cultura e evolução (2a ed. rev. e ampl.) (M. T. A. Silva, G. Tomanari, E. Z. Tourinho, \& M. A. Matos, trad.). Porto Alegre: Artmed.

Baum, W. M. (2011). What is radical behaviorism? A review of jay moore's conceptual foundations of radical behaviorism. Journal of the Experimental Analysis of Behavior, 95(1), 119-126.

Bazart, C., \& Pickhardt, M. (2011, January). Fighting income tax evasion with positive rewards. Public Finance Review, 39(1), 124-149.

Beccaria, C. (2012). Dos delitos e das penas (N. C. Lima, trad.). São Paulo: Hunter Books (Obra original publicada em 1764).

Becker, A. A. (1999). Carnaval tributário (2a ed.). São Paulo: Lejus.

Becker, G. S. (1968). Crime and punishment: an economic approach. Journal of Political Economy, 76, 169-217.

Benk, S., \& Budak, T. (2012). Power and trust as determinants of voluntary versus enforced tax compliance: empirical evidence for the slippery slope framework from Turkey. African Journal of Business Management, 6(4), 1499-1505.

Bêrni, D. A., \& Fernandez, B. P. M. (Orgs.) (2015). Métodos e técnicas de pesquisa: modelando as ciências empresariais. São Paulo: Saraiva. 
Bird, R. M., Martinez-Vazquez, J., \& Torgler, B. (2008). Tax effort in developing countries and high income countries: the impact of corruption, voice and accountability. Economic Analysis and Policy, 38(1), 55-71.

Bobek, D. D., \& Hatfield, R. C. (2003). An investigation of the theory of planned behavior and the role of moral obligation in tax compliance. Behavior Research in Accounting, 15, 1338 .

Borges, M. M., \& Medeiros, C. A. (2007). Princípios básicos de análise do comportamento. Porto Alegre: Artmed.

Bosco, L., \& Mittone, L. (1997). Tax evasion and moral constraints: some experimental evidence. Kyklos, 50, 297-324.

Boylan, S. J., \& Sprinkle, G. B. (2001, Spring). Experimental evidence on the relation between tax rates and compliance: the effect of earned vs. endowed income. The journal of the American Taxation Association, 23(1), 75-90.

Braithwaite, V. (1995). Games of engagement: postures within the regulatory community. Law and Policy, 17(3), 225-255.

Braithwaite, V. (2003). Dancing with tax authorities: motivational postures and non-compliant actions. In V. Braithwaite (Org.). Taxing democracy: understanding tax avoidance and evasion (pp. 15-39). Aldershot, UK: Ashgate Publishing Ltd.

Braithwaite, V. (2009). Defiance in taxation and governance: resisting and dismissing authority in a democracy. Cheltenham, UK: Edward Elgar Publishing Ltd.

Braithwaite, V. (2011). Resistant and dismissive defiance toward tax authorities. In A. Crawford \& A. Hucklesby (Eds.). Legitimacy and compliance in criminal justice. Abingdon: Routledge.

Bryant, S., Hunton, J., \& Stone, D. (2004). Internet-based experiments: prospects and possibilities for behavioral accounting research. Behavioral Research in Accounting, 16(1), 107-129.

Bussab, W. O., \& Morettin, P. A. (2004). Estatística básica (5a ed., 4a tir. ver. e atual.). São Paulo: Saraiva.

Campbell, D., \& Stanley, J. (1973). Experimental and quasi-experimental designs for research. Chicago: Rand-McNally.

Carvalho, M. B., Neto (2002). Análise do comportamento: behaviorismo radical, análise experimental do comportamento e análise aplicada do comportamento. Interação em Psicologia, 6(1), 13-18. 
Cook, T., \& Campbell, D. (1979). Design and analysis for field settings. Chicago: Rand McNally.

Corrar, L. J., Paulo, E., \& Dias, J. M., Filho (Coords.) (2007). Análise multivariada: para os cursos de administração, ciências contábeis e economia. Fundação Instituto de Pesquisas, Contábeis, Atuariais e Financeiras - Fipecafi. São Paulo: Atlas.

Cozby, P. C. (2003). Métodos de pesquisa em ciências do comportamento. São Paulo: Atlas.

Dalmácio, F. Z., Berger, F. S., Dallapicula, T. M., \& Alencar, R. C. (2009). A ética da evasão fiscal: um estudo comparativo de profissionais e estudantes da área de negócios. Anais do International Accounting Congress - IAAER \& ANPCONT, São Paulo, SP, Brasil, 3. Recuperado em 12 dezembro, 2014, de http://www.fucape.br/_public/producao_cientifica/2/Zoboli\%20\%20A\%20etica\%20da\%20evas\%C3\%A30\%20fiscal.pdf

Darwin, C. (1859). On the origin of species or the preservation of favoured races in the struggle for life. Londres: John Murray.

Devos, K. (2008). Tax evasion behaviour and demographic factors: an exploratory study in Australia. Revenue Law Journal, 18(1), 1-44.

Dubin, J. A., Graetz, M., \& Wilde, L. L. (1990). The effect of audit rates on the federal individual income tax, 1977-1986. National Tax Journal, 43(4), 395-409.

Dubin, J. A., \& Wilde, L. L. (1988). An empirical analysis of federal income tax auditing and compliance. National Tax Journal, 61(1), 61-73.

Erard, B. (1992). The influence of tax audits on reporting behavior. In J. Slemrod (Ed.) Why people pay taxes (pp. 95-114). Washington, D.C.: Urban Institute Press.

Erard, B., \& Feinstein, J. S. (1994). The role of moral sentiments and audit perceptions in tax compliance. Public Finance, 49, 70-89.

Falkinger, J., \& Walther, H. (1991). Rewards versus penalties: on a new policy against tax evasion. Public Finance Quarterly, 19, 67-79.

Fávero, L. P., Belfiore, P., Silva, F. L., \& Chan, B. L. (2009). Análise de dados: modelagem multivariada para tomada de decisões. Rio de Janeiro: Elsivier.

Feld, L. P., \& Frey, B. S. (2002). Trust breeds trust: how taxpayers are treated. Economics of Governance, 3, 87-99. 
Feld, L. P., \& Frey, B. S. (2007, January). Tax compliance as the result of a psychological tax contract: the role of incentives and responsive regulation. Law \& Policy, 29(1), 102-120.

Feld, L. P., Frey, B. S., \& Torgler, B. (2006). Rewarding honest taxpayers? Evidence on the impact of rewards from field experiments. CREMA Working Paper № 16. Center for Research in Economics, Management and the Arts (CREMA). Retrieved May 07, 2015, from http://www.crema-research.ch/papers/2006-16.pdf

Frank, R. (1987, September). If homo economics could choose his own utility function, would he want one with a conscience? The American Economic Review, 77(4), 593-604).

Frey, B. S., \& Torgler, B. (2007). Tax morale and conditional cooperation. Journal of Comparative Economics, 35, 136-159.

Friedland, N., Maital, S., \& Rutenberg, A. (1978). A simulation study of income tax evasion. Journal of Public Economics, 10, 107-116.

Friedman, D., \& Sunder, S. (1994). Experimental methods: a primer for economists. Cambridge: Cambridge University Press.

Gangl, K., Müehlbacher, S., Groot, M., Goslinga, S., Hofmann, E., Kogler, C., Antonides, G., \& Kirchler, E. (2013). How can I help you? Perceived service orientation of tax authorities and tax compliance. FinanzArchive: Public Finance Analysis, 69(4), 487-510.

Garson, G. D. (2001). Guide to writing empirical papers, theses, and dissertations. New York: CRC Press.

Geest, G. de, \& Dari-Mattiacci, G. (2013). The rise of carrots and the decline of sticks. The University of Chicago Law Review, 80(1), 341-392.

Gemmell, N., \& Ratto, M. (March, 2012). Behavioral responses to taxpayer audits: evidence from random taxpayer inquiries. National Tax Journal, 65(1), 33-58.

Goulart, P. R. K., Delage, P. E. G. A., Rico, V. V., \& Brino, A. L. F. (2012). Bases filosóficas e noção de ciência em análise do comportamento. In M. M. C. Hübner \& M. B. Moreira (Coords.). Fundamentos de psicologia. (Série Temas clássicos da psicologia sob a ótica da análise do comportamento, Cap. 2). Rio de Janeiro: Guanabara Koogan.

Grossfeld, B., \& Bryce, J. (1983). A brief comparative history of the origins of the income tax in Great Britain, Germany and the United States. The American Journal of Tax Policy, 2, 211251.

Hair, J. F., Black, W. C., Babin, B. J., Anderson, R. E., \& Tatham, R. L. (2006). Multivariate data analysis (6a ed.). New Jersey: Prentice Hall. 
Halla, M. (2012, April). Tax morale and compliance behavior: first evidence on a causal link. The B. E. Journal of Economic Analysis \& Policy, 12(1), 1-27.

Hammar, H., Jagers, S. C., \& Nordblom, K. (2009). Perceived tax evasion and the importance of trust. The Journal of Socio-Economics, 38(2), 238-245.

Hartner, M., Rechberger, S., Kirchler, E., \& Schabmann, A. (2008). Procedural fairness and tax compliance. Economic Analysis and Policy, 38(1), 137-152.

Hasseldine, J. (1998), Tax amnesties: an international review. Bulletin for International Fiscal Documentation, 52, 303-310.

Hora, H. R., Monteiro, G. T., \& Arica, J. (2010). Um estudo com o coeficiente Alfa de Cronbach. Produção \& Produção, 11(2), 85-103.

Hübner, M. M. C., Bortoli, E., Almeida, P., \& Cruvível, A. C. (2012). Bases filosóficas e noção de ciência em análise do comportamento. In M. M. C. Hübner \& M. B. Moreira (Coords.). Fundamentos de psicologia. (Série Temas clássicos da psicologia sob a ótica da análise do comportamento, Cap. 7). Rio de Janeiro: Guanabara Koogan.

Jourard, S. M. (1969). The effects of experimenters' self-disclosure on subjects' behavior. In C. D. Spielberger (Org.). Current topics in clinical and community psychology (Vol. 1). New York: Academic Press.

Kantowitz, B. H., Roediger, H. L., III, \& Elmes, D. G. (2009). Experimental psychology (9. ed.). Belmonte, CA: Wadsworth Publishing Company.

Kastlunger, B., Kirchler, E., Mittone, L., \& Pitters, J. (2009). Sequences of audits, tax compliance, and taxpaying strategies. Journal of Economic Psychology, 30(4), 405-418.

Kastlunger, B., Lozza, E., Kirchler, E., \& Schabmann, A. (2013). Powerful authorities and trusting citizens: the slippery slope framework and tax compliance in Italy. Journal of Economic Psychology, 34, 36-45.

Kastlunger, B., Müehlbacher, S., Kirchler, E., \& Mittone, L. (2011). What goes around comes around? Experimental evidence of the effect of rewards on tax compliance. Public Finance Review, 39(1), 150-167.

Kirchler, E. (1997a). Balance between giving and receiving: tax morality and satisfaction with fiscal policy as they relate to the perceived just distribution of public resources. Reitaku International Journal of Economic Studies, 5, 59-70. 
Kirchler, E. (1997b). The burden of new taxes: acceptance of taxes as a function of affectedness and egoistic versus altruistic orientation. Journal of Behavioral and Experimental Economics, 26(4), 421-437.

Kirchler, E. (1999). Reactance to taxation: employers' attitudes towards taxes. Journal of SocioEconomics, 28, 131-138.

Kirchler, E. (2007). The economic psychology of tax behaviour. Cambridge, UK: Cambridge University Press.

Kirchler, E., Kogler, C., \& Müehlbacher, S. (2014). Cooperative tax compliance: from deterrence to deference. Current Directions in Psychological Science, 23(2), 87-92.

Kirchler, E., Müehlbacher, S., Kastlunger, B., \& Wahl, I. (2010). Why pay taxes? A review of tax compliance decisions. In J. Alm, J. Martinez-Vazquez \& B. Torgler (Eds.). Developing alternative frameworks for explaining tax compliance (pp. 15-31). Abingdon, UK: Routledge.

Kogler, C., Batrancea, L., Nichita, A., Pantya, J., Belianin, A., \& Kirchler, E. (2013). Trust and power as determinants of tax compliance: testing the assumptions of the slippery slope framework in Austria, Hungary, Romania and Russia. Journal of Economic Psychology 34, 169-180.

Lederman, L. (2003). The interplay between norms and enforcement in tax compliance. Ohio State Law Journal, 64(6), 1453-1514.

Lemoine, J., \& Roland-Lévy, C. (2012). From the 'slippery slope framework' to 'responsive regulation'. In P. Cunningham \& N. Fretwell (Eds.). Creating communities: local, national and global (pp. 727-739). London: CiCe.

Leviner, S. (2008). An overview: a new era of tax enforcement - from "big stick" to responsive regulation. Regulation \& Governance, 2, 360-380.

Libby, R., Bloomfield, R. J., \& Nelson, M. W. (2002). Experimental research in financial accounting. Accounting, Organizations and Society, 27, 775-810.

Lipsey, M. W., \& Hurley, S. M. (2009). Design sensitivity. In L. Bickman, \& D. J. Rog. The SAGE handbook of applied social research methods (2a ed., pp. 44-76). London: Sage Publications.

Lisi, G. (2012a). Testing the slippery slope framework. Economics Bulletin, 32, 1369-1377.

Lisi, G. (2012b, September). Unemployment, tax evasion and the slippery slope framework. International Review of Economics, 59(3), 297-302. 
Lozza, E., Kastlunger, B., Tagliabue, S., Kirchler, E. (2013). Political ideology and tax compliance. Journal of Social and Political Psychology, 1(1), 51-73.

Martins, G. A., \& Domingues, O. (2011). Estatística geral e aplicada (4a ed. rev. e ampl.). São Paulo: Atlas.

Martins, G. A., \& Theóphilo, C. R. (2009). Metodologia da investigação cientifica para ciências sociais aplicadas (2a. ed.). São Paulo: Atlas.

Marton, R. (2003). Reflexões sobre a sonegação tributária. In A. P. C. Medeiros. (Org.). Perspectivas contemporâneas para o direito (pp. 263-277). Brasília: Editora Universa.

Matos, M. A. (1981). A ética do exercício de controles aversivos. Boletim de Psicologia, 33(81), 126-133.

Matos, M. A. (2001). Comportamento governado por regras. Revista Brasileira de Terapia Comportamental e Cognitiva, 3(2), 51-66.

McGee, R. W., Ho, S. S. M., \& Li, A. Y. S. (2008). A comparative study on perceived ethics of tax evasion: Hong Kong vs The United States. Journal of Business Ethics, 77, 147-158.

Melis, F. (1950). Storia della ragioneria. Bologna: Dott. Cesare Zuffi. In S. ludícibus, E. Martins \& L. N. Carvalho (2005). Contabilidade: aspectos relevantes da epopéia de sua evolução. Revista Contabilidade \& Finanças, 16(38), 7-19. Recuperado em 12 abril, 2015, de http://www.scielo.br/scielo.php?script=sci_arttext\&pid=S1519-

70772005000200002\&Ing=en\&tIng=pt. 10.1590/S1519-70772005000200002)

Melo, C. M., Garcia, L. T., Rose, J. C. C., \& Faleiros, P. (2012). Bases filosóficas e noção de ciência em análise do comportamento. In M. M. C. Hübner \& M. B. Moreira (Coords.). Fundamentos de psicologia. (Série Temas clássicos da psicologia sob a ótica da análise do comportamento, Cap. 12). Rio de Janeiro: Guanabara Koogan.

Milone, G. (2006). Estatística geral e aplicada. São Paulo: Thomson Learning.

Mittone, L. (2006). Dynamic behaviour in tax evasion: an experimental approach. The Journal of Socio-Economics, 35(5), 813-835.

Moreira, M. B., \& Hanna, E. S. (2012). Bases filosóficas e noção de ciência em análise do comportamento. In M. M. C. Hübner \& M. B. Moreira (Coords.). Fundamentos de psicologia. (Série Temas clássicos da psicologia sob a ótica da análise do comportamento, Cap. 1). Rio de Janeiro: Guanabara Koogan. 
Müehlbacher, S., \& Kirchler, E. (2013). Mental accounting of self-employed taxpayers: on the mental segregation of the net income and the tax due. FinanzArchiv: Public Finance Analysis, 69(4), 412-438.

Müehlbacher, S., Kirchler, E., \& Schwarzenberger, H. (2011). Voluntary versus enforced tax compliance: empirical evidence for the "slippery slope" framework. Eur J Law Econ, 32, 89-97.

Murphy, K. (2008). Enforcing tax compliance: to punish or persuade? Economic Analysis and Policy, 38(1).

Murphy, K., \& Davidshofer, C. (1988). Psychological testing: principles and applications. Englewood Cliffs, N. J.: Prentice-Hall.

Murray, M. N. (1995, December). Sales tax compliance and audit selection. National Tax Journal, 48(4), 515-530.

Neter, J., Kutner, M. H., Nachtshein, C. J., \& Wasserman, W. (1996). Aplied linear statistical models (4th ed.). Boston: WCB/McGraw-Hill.

Orviska, M., \& Hudson, J. (2002). Tax evasion, civic duty and law abiding citizen. European Journal of Political Economy, 19, 83-102.

Plumley, A. H. (1996, November). The determinants of individual income tax compliance: estimating the impacts of tax policy, enforcement, and IRS responsiveness. Internal Revenue Service Publication. Washington, DC: U. S. Department of the Treasury.

Posner, E. A. (2000). Law and social norms: the case of tax compliance. Virginia Law Review, 86, 1781-1819.

Raskolnikov, A. (2006, April). Crime and punishment in taxation: deceit, deterrence, and the self-adjusting penalty. Columbia Law Review, 106(3), 569-642.

Reckers, P. M. J., Sanders, D. L., \& Roark, S. J. (1994, December). The influence of ethical attitudes on taxpayer compliance. National Tax Journal, 47(4), 825.

Russell, B., (1961). The basic writings of Bertrand Russel 1903-1959. London: G. Allen \& Unwin.

Sayeg, R. N. (2003). Sonegação tributária e complexidade: uma visão multidimensional. RAEeletrônica, 2(1), 1-16. Recuperado em 15 Dezembro, 2014, de http://rae.fgv.br/sites/rae.fgv.br/files/artigos/10.1590_S1676-56482003000100010.pdf

Schwarz, D., Flamant, R., \& Lellouch, J. (1980). Clinical trials. Londres: Academic Press. 
Shadish, W. R., Cook, T. D., \& Campbell, D. T. (2002). Experimental and quasi-experimental designs for generalized causal inference (2a ed.). Boston: Houghton Mifflin.

Sidman, M. (2009). Coerção e suas implicações (M. A. Andery \& T. M. Sério, trad.). Boston: Editora Authors Cooperative (Obra original publicada em 1989).

Siqueira, M. L., \& Ramos, F. S. (2005, set./dez.). A economia da sonegação: teorias e evidências empíricas. Revista de Economia Contemporânea, 9(3), 555-581.

Siqueira, M. L., \& Ramos, F. S. (2006). Evasão fiscal do imposto sobre a renda: uma análise do comportamento do contribuinte ante o sistema impositivo brasileiro. Economia Aplicada, 10(3), 399-424.

Skinner, B. F. (1978). O comportamento verbal. São Paulo: Cultrix.

Skinner, B. F. (1983). O mito da liberdade. São Paulo: Summus.

Skinner, B. F. (2003). Ciência e comportamento humano (11a ed.) (J. C. Todorov, trad.). São Paulo: Editora Martins Fontes (Obra original publicada em 1953).

Skinner, B. F. (2006). Sobre o behaviorismo (10a ed.) (M. P. Villalobos, trad.) São Paulo: Cultrix (Obra original publicada em 1974).

Skinner, B. F. (2007). Seleção por consequências. Revista Brasileira de Terapia Comportamental e Cognitiva, 9, 129-137.

Skinner, B. F. (2013). Walden II: uma sociedade do futuro (R. Moreno \& N. R. Saraiva, trads.) (Obra original publicada em 1969). São Paulo: E. P. U.

Skinner, J., \& Slemrod, J. (1985). An economic perspective on tax evasion. National Tax Journal, 38, 345-353.

Slemrod, J. (1985, May). An empirical test for tax evasion. The Review of Economics and Statistics, 67(2), 232-238.

Smith, K. W., \& Stalans, L. J. (1991). Encouraging tax compliance with positive incentives: a conceptual framework and research directions. Law \& Policy, 13, 35-53.

Spicer, M. N., \& Becker, L. A. (1980, June). Fiscal inequity and tax evasion: an experimental approach. National Tax Journal, 33(2), 171-175.

Spicer, M. W., \& Thomas, J. E. (1982, September). Audit probabilities and tax evasion decision: an experimental approach. Journal of Economic Psychology, 2(3), 241-245. 
Spicer, M. W., \& Rodney, E. (1985). Hero.tax evasion andheuristics: a research note. Journal of Public Economics, 26, 263-267.

Sprinkle, G. B. (2003). Perspectives on experimental research in managerial accounting. Organizations and Society, 28(2-3), 287-318.

Srinivasan, T. N. (1973). Tax evasion: a model. Journal of Public Economics, 2, 339-346.

Torgler, B. (2003a, June). Beyond punishment: a tax compliance experiment with taxpayers in Costa Rica. Revista de Analisis Economico, 18(1), 27-56.

Torgler, B. (2003b). Tax morale, rule governed behaviour and trust. Constitutional Political Economy, 14, 119-140.

Wahl, I., Kastlunger, B., \& Kirchler, E. (2010, October). Trust in authorities and power to enforce tax compliance: an empirical analysis of the "slippery slope framework". Law \& Policy, 32(4), 383-406.

Webley, P. (1987). Audit probabilities and tax evasion in a business simulation. Economics Letters, 25(3), 267-270.

Weigel, R. H., Hessing, D. J., \& Elffers, H. (1987). Tax evasion research: a critical appraisal and theoretical model. Journal of Economic Psychology, 8(2), 215-235.

Yaremko, R. M., Harari, H., Harrison, R. C., \& Lynn, E. (1986). Handbook of research and quantitative methods in psychology: for students and professionals (p. 72). New Jersey: Lawrence Erlbaum Associates. 
APÊNDICES

APÊNDICE A

PRINTS DE TELAS DA PESQUISA ON-LINE

\section{BEM-VINDO À VERMONDE}

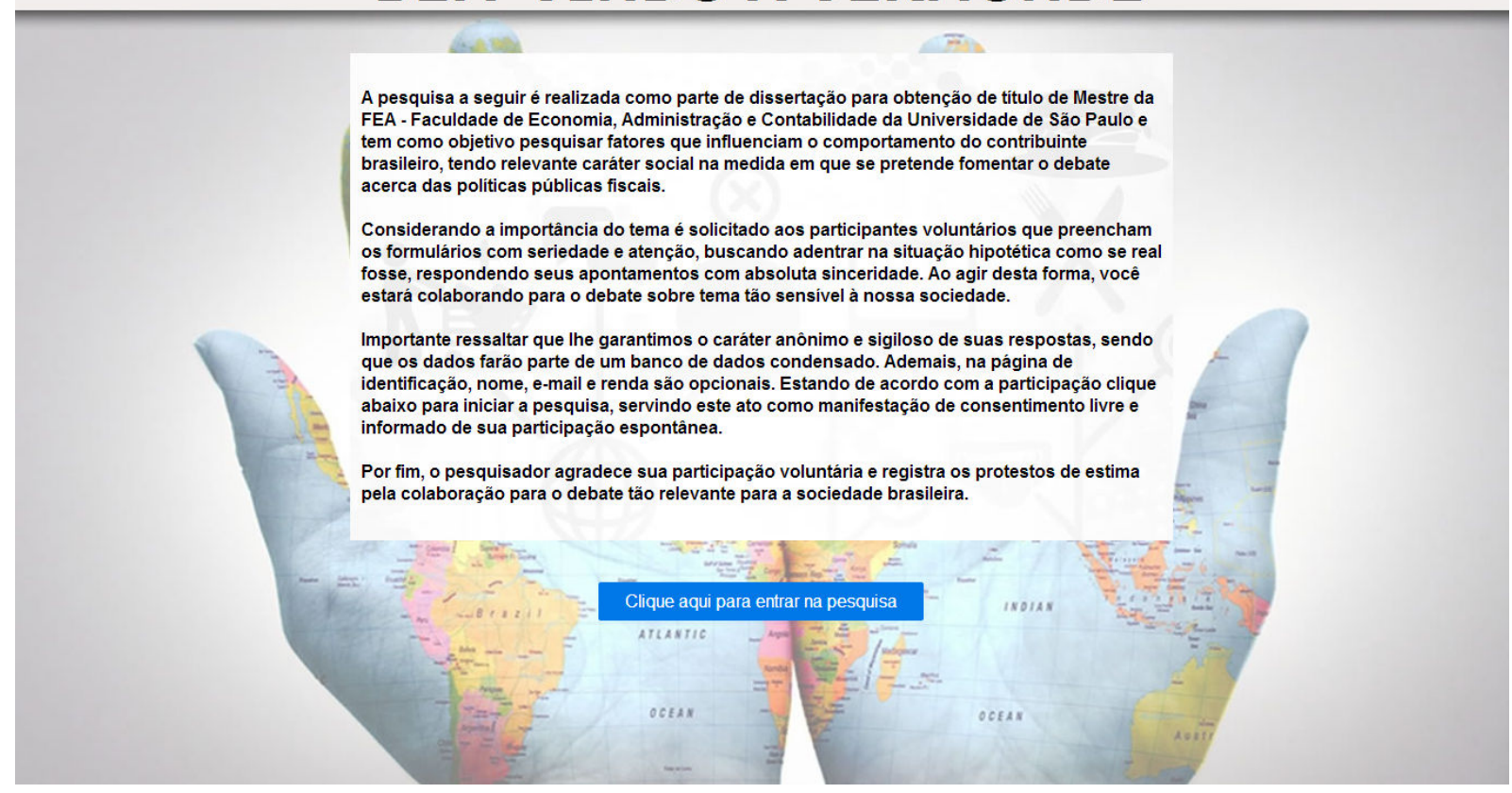

Figura 1 - Tela de boas-vindas 


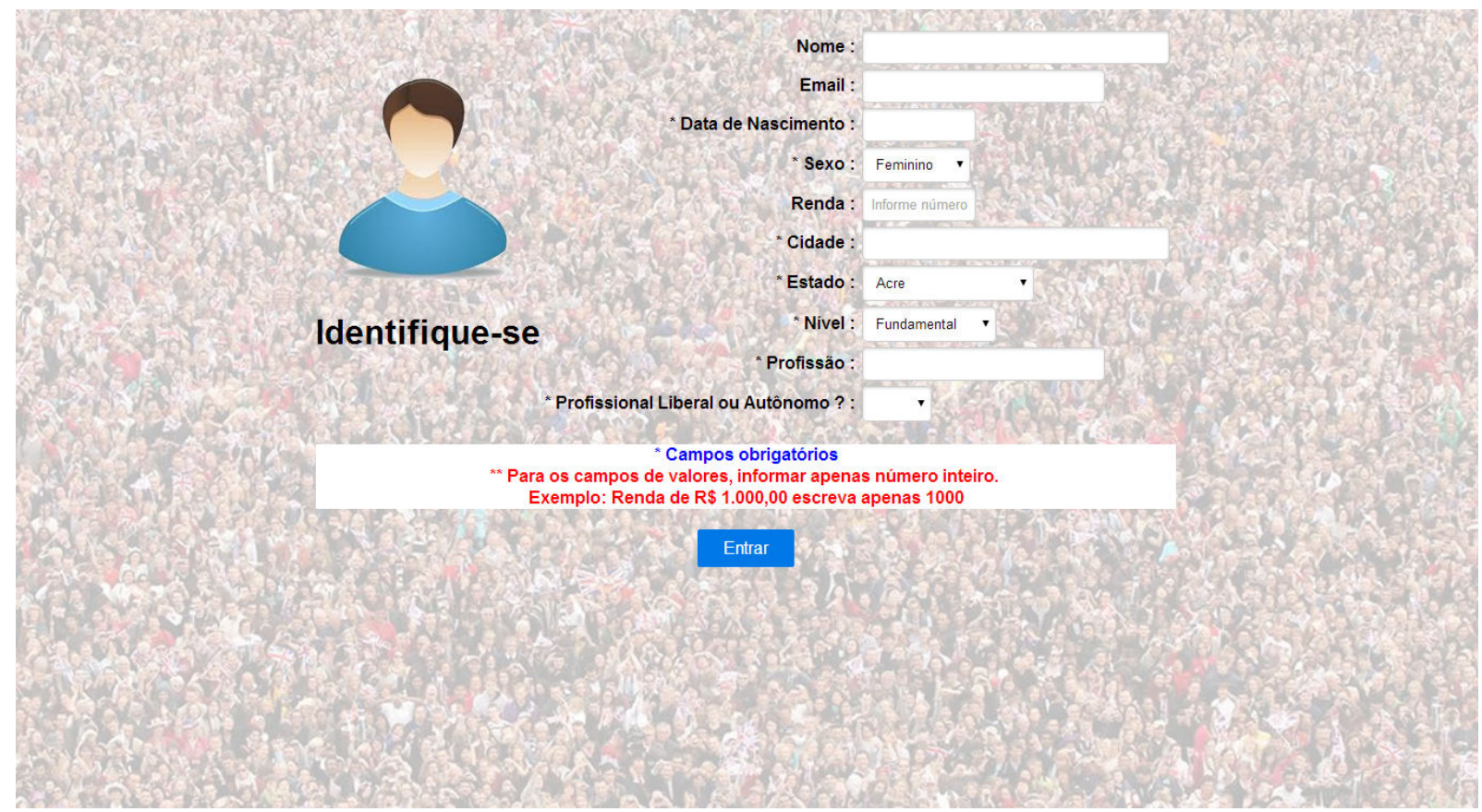

Figura 2 - Tela de identificação 


\section{INSTRUÇÕES - $1 / 4$}

A seguir você receberá informações acerca do país em que vive. Imagine fortemente que realmente vive neste país e faça seus apontamentos de acordo com esta premissa.

A cada nova etapa você poderá receber uma informação e, então, deverá apontar pelo valor a ser pago de imposto que optará durante o período. Ao final, responda o questionário e o experimento será encerrado.

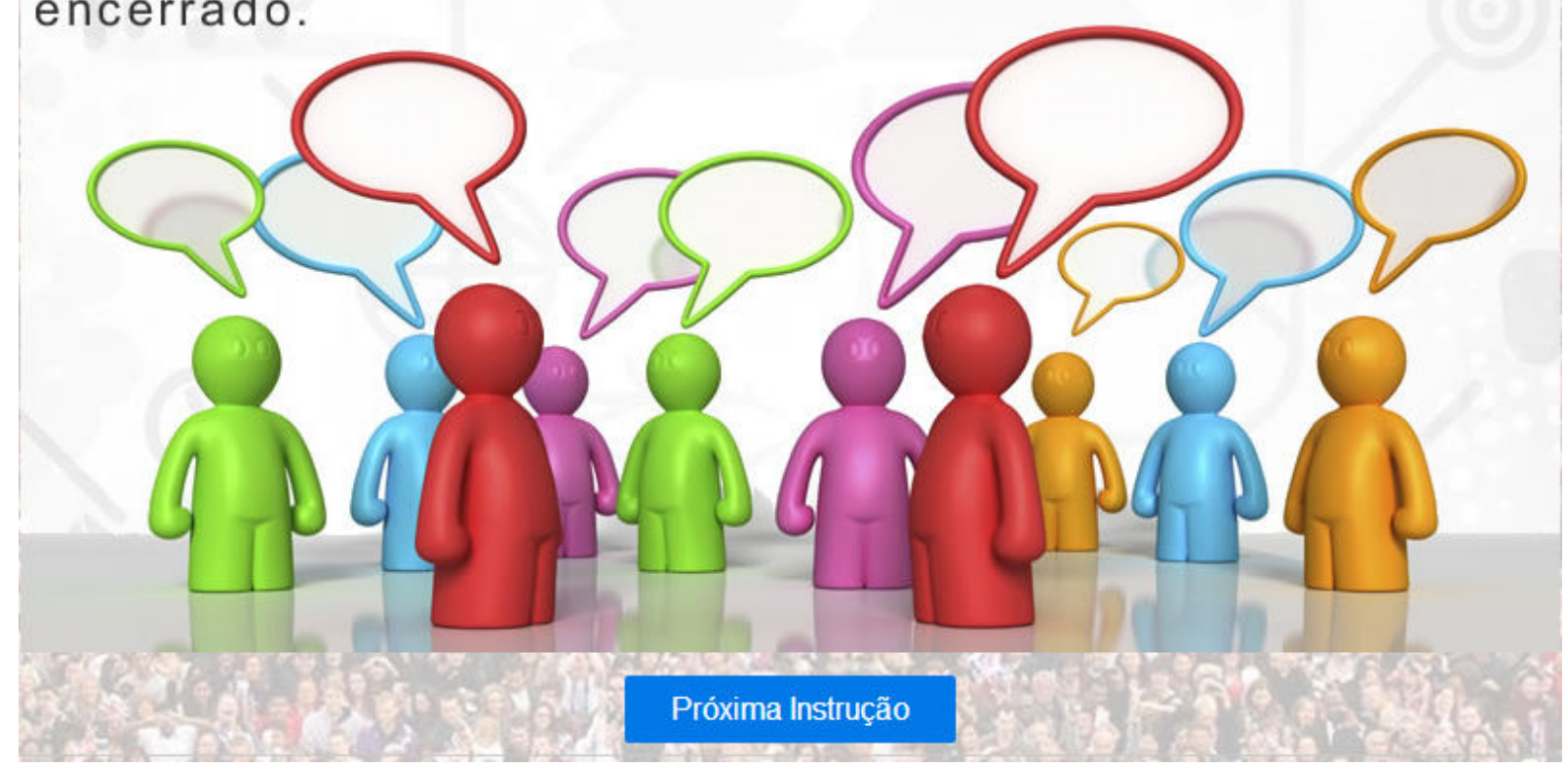

Figura 3 - Tela de instruções 1/4 


\section{INSTRUÇÕES - 2/4}

Você é cidadão de Vermonde, estando empregado e deverá declarar e pagar seu imposto durante diversos períodos consecutivos;

Não há retenção de tributos na fonte em Vermonde. Vale dizer que a opção em cumprir integralmente a determinação da lei sobre o montante a ser recolhido compete exclusivamente a você, sujeitando-se as fiscalizações por parte do Governo;

Antes de declarar e pagar seu imposto de renda você poderá receber informações sobre questões de naturezas diversas;

Seu rendimento por período é de $\$ 5.200,00$ (em moeda corrente de Vermonde);

A aliquota efetiva do imposto de renda prevista em lei é de 15\%;

Você deverá decidir qual o montante de tributos irá pagar até o limite da carga tributária prevista em lei. Em outras palavras decidirá entre pagar em cada período de $\$ 0$ até $\$ 780,00$;

Caso você seja autuado por sonegação fiscal, ou seja, quando não recolher o valor integral do tributo conforme previsto em lei, a multa será de $50 \%$ do valor da sonegação;

O período de prescrição e decadência é de 03 (três anos). Isso significa que caso você seja fiscalizado o Governo irá avaliar os 03 (três) últimos períodos buscando eventual recolhimento inferior ao percentual determinado pela lei;

O valor que lhe restará, portanto, é o valor de seu rendimento subtraído do valor dos tributos pagos e, se o caso, do valor da multa por sonegação fiscal.

\section{Próxima Instrução}

Figura 4 - Tela de instruções 2/4 


\section{INSTRUÇÕES - 3/4}

Vermonde é um país onde nasceu e vive e que no último censo realizado em Janeiro de 2013 constatou-se uma população total de 16.336 .000 habitantes. A taxa de desemprego encontra-se na média mundial.

Desde sua independência em 1849 o país se caracteriza por possuir pouca estabilidade política e um governo oligárquico, onde o poder está concentrado na mão de poucos. Raramente são realizados referendos para que os cidadãos de Vermonde expressem sua opinião sobre o conjunto de leis que estão sendo debatidas no Congresso.

O Governo possui uma má reputação perante o povo. Segundo pesquisas $70 \%$ da população não está satisfeita com o atual Governo.

A carga tributária não é distribuída de forma igualitária entre a população, ou seja, não está de acordo com a sua ocupação e remuneração. O povo de Vermonde possui a opinião de que não é dever de todo cidadão contribuir para a arrecadação de tributos.

A legislação do país não é transparente e não existem centros de informação que ofereçam aconselhamento gratuito à população sobre assuntos judiciais e questões tributárias. Além disso, as autoridades de Vermonde são pouco focadas na prestação de serviço ao povo e pouco interessadas em oferecer suporte aos cidadãos.

A população é mal informada sobre os gastos do Governo, na medida em que eles não são regularmente divulgados, o que impossibilita a todos saber onde está sendo aplicado o dinheiro de seus tributos. Uma pesquisa realizada em novembro de 2012 demonstrou que $78 \%$ da população entende que o dinheiro que gastam com tributos não é utilizado de forma adequada pelo Governo.

Além disso, uma grande parte da arrecadação tributária é desviada por políticos. De acordo com um índice de corrupçẫo internacional Vermonde é um dos paises com a maior taxa de corrupção do mundo.

Todos estes fatores acarretam pouca confiança da população no pais e em seus governantes.

\section{Próxima Instrução}

Figura 5 - Tela de instruções 3/4 


\section{INSTRUÇÕES - 4/4}

A fiscalização sobre sonegação fiscal em Vermonde não é muito eficaz. Por causa da complexa legislação fiscal é dificil para o governo realizar fiscalizações em seus cidadãos e empresas e com isso autuar os sonegadores.

O governo atribui um baixo orçamento para a administração fiscal realizar fiscalizações e coibir a sonegação. Com os meios disponiveis é impossivel para a administração empregar inspetores fiscais muito qualificados. Além disso, a população considera os auditores fiscais ausentes no cotidiano do pais.

A chance de ser fiscalizado em Vermonde é considerada baixa, em outras palavras, as pessoas e empresas não são fiscalizadas com frequência. Portanto, a maior parte das práticas de sonegação fiscal não é detectada. Além disso, as multas por sonegação de impostos são consideradas baixas em Vermonde. Quando os sonegadores de tributos são detectados, eles não precisam antecipar o pagamento de severas multas. A administração fiscal é benevolente com os sonegadores.

Todos esses fatores fazem com que os cidadãos de Vermonde avaliem o Governo como pouco capaz de controlar a sonegação fiscal.

Figura 6 - Tela de instruções $4 / 4$ 


\section{PERÍODO 1}

Considere as informações recebidas anteriormente e informe o valor que pagará de tributos neste PERIODO

Valor de imposto a pagar: Informe o valor a pagar

Figura 7 - Período 1 de pagamentos

\section{Muito obrigado pela sua participação !}

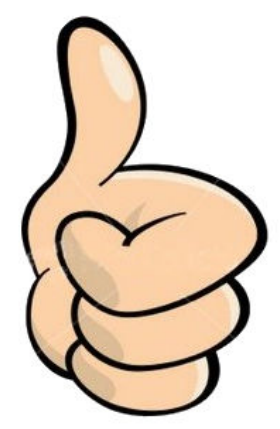

Figura 8 - Tela de agradecimento 


\section{APÊNDICE B}

\section{PRINTS DE TELAS DO EXPERIMENTO}

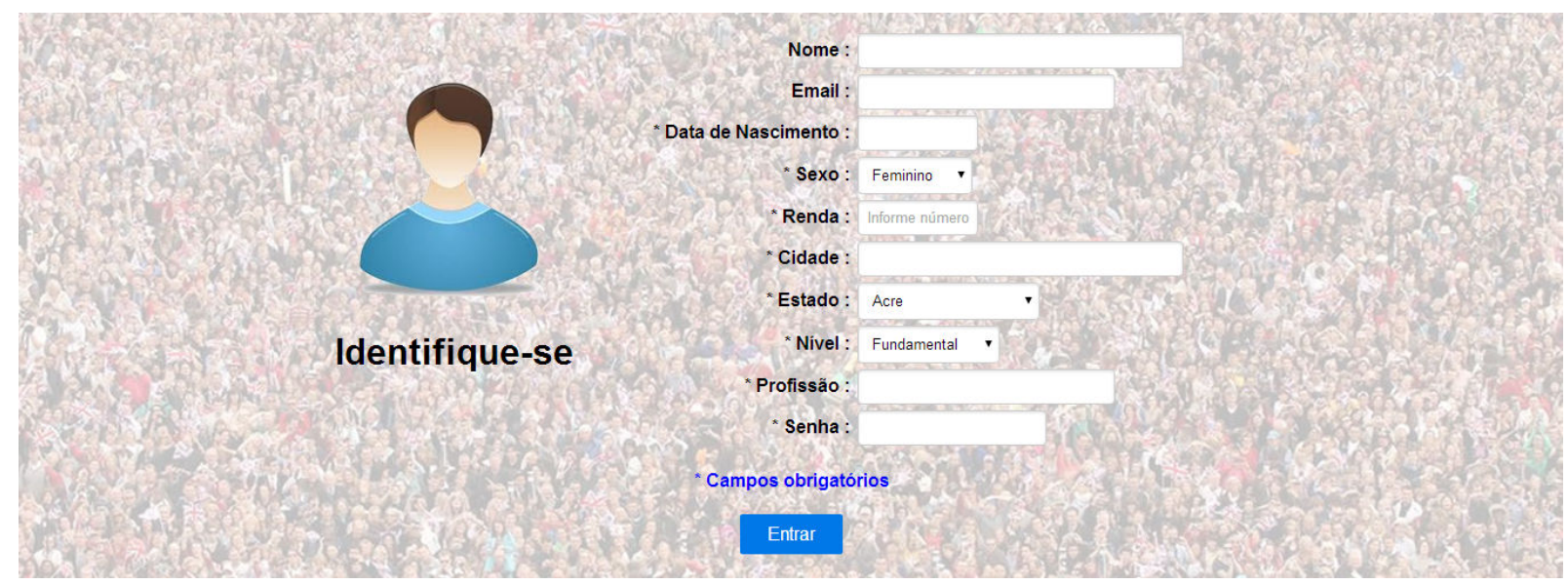

Figura 1 - Tela de identificação

\section{PERÍODO 2}

O Governo promulgou uma lei que $20 \%$ do imposto de renda que recolher irá compor um fundo de investimento em melhorias no bairro em que reside. Pelas ruas do seu bairro você nota obras de melhorias financiadas por este fundo.

Considere as informações até aqui recebidas e informe o valor que pagará de tributos neste PERIODO:

Valor de imposto a pagar: Informe o valor a pagar

Figura 2 - Período 2 com recompensa (Grupo Recompensas) 


\section{PERÍODO 2}

ATENÇÃO : Você caiu na malha fina e suas declaraçöes anteriores foram fiscalizadas. Em razão do procedimento fiscal foi multado em \$ 570

Considere as informações até aqui recebidas e informe o valor que pagará de tributos neste PERIODO

Valor de imposto a pagar : Informe o valor a pagar

Próximo Periodo

Figura 3 - Período 2 com punições (Grupo Punições) 


\section{APÊNDICE C \\ REPRODUÇÃO EM TEXTO DA PESQUISA ON-LINE}

\section{Tela inicial}

A pesquisa a seguir é realizada como parte de dissertação para obtenção de título de Mestre em Contabilidade pela FEA - Faculdade de Economia, Administração e Contabilidade da Universidade de São Paulo e tem como objetivo pesquisar fatores que influenciam o comportamento do contribuinte brasileiro, tendo relevante caráter social na medida em que se pretende fomentar o debate acerca das políticas públicas fiscais.

Considerando a importância do tema é solicitado aos participantes voluntários que preencham os formulários com seriedade e atenção, buscando adentrar na situação hipotética como se real fosse, respondendo seus apontamentos com absoluta sinceridade. Ao agir desta forma, você estará colaborando para o debate sobre tema tão sensível à nossa sociedade.

Importante ressaltar que lhe garantimos o caráter anônimo e sigiloso de suas respostas, sendo que os dados farão parte de um banco de dados condensado. Ademais, na página de identificação, nome, e-mail e renda são opcionais. Estando de acordo com a participação clique abaixo para iniciar a pesquisa, servindo este ato como manifestação de consentimento livre e informado de sua participação espontânea.

Por fim, o pesquisador agradece sua participação voluntária e registra os protestos de estima pela colaboração para o debate tão relevante para a sociedade brasileira.

\section{Instruções 1/4}

A seguir você receberá informações acerca do país em que vive. Imagine fortemente que realmente vive neste país e faça seus apontamentos de acordo com esta premissa. 
A cada nova etapa você poderá receber uma informação e, então, deverá apontar pelo valor a ser pago de imposto que optará durante o período. Ao final, responda o questionário e o experimento será encerrado.

\section{Instruções 2/4}

- Você é cidadão de Vermonde e está empregado. A legislação local determina que a cada ano declare e pague seu imposto de renda de acordo com exigido;

- Não há retenção de tributos na fonte em Vermonde. Vale dizer que a opção em cumprir integralmente a determinação da lei sobre o montante a ser recolhido compete exclusivamente a você, sujeitando-se as fiscalizações por parte do Governo;

- $\quad$ Antes de declarar e pagar seu imposto de renda você poderá receber informações sobre questões de naturezas diversas;

- $\quad$ Seu rendimento por período é de $\$ 5.200,00$ (em moeda corrente de Vermonde);

- A alíquota efetiva do imposto de renda prevista em lei é de 15\%;

- Você deverá decidir qual o montante de tributos irá pagar até o limite da carga tributária prevista em lei. Em outras palavras decidirá entre pagar em cada período de $\$$ 0 até \$780,00;

- Caso você seja autuado por sonegação fiscal, ou seja, quando não recolher o valor integral do tributo conforme previsto em lei, a multa será de $50 \%$ do valor da sonegação;

- $\quad$ O período de prescrição e decadência é de 03 (três anos). Isso significa que caso você seja fiscalizado o Governo irá avaliar os 03 (três) últimos períodos buscando eventual recolhimento inferior ao percentual determinado pela lei;

- O valor que Ihe restará, portanto, é o valor de seu rendimento subtraído do valor dos tributos pagos e, se o caso, do valor da multa por sonegação fiscal.

\section{Instruções 3/4 - Grupo Alta Confiança}


Vermonde é um país onde nasceu e vive e que. No último censo realizado em Janeiro de 2013 contatou-se uma população total de 16.336.000 habitantes. A taxa de desemprego encontra-se na média mundial.

Desde sua independência em 1849 o país se caracteriza por possuir muita estabilidade política e um governo democrático. Regularmente são realizados referendos para que os cidadãos de Vermonde expressem sua opinião sobre o conjunto de leis que estão sendo debatidas no Congresso.

O Governo possui uma boa reputação perante o povo. Segundo pesquisas $70 \%$ da população está satisfeita com o atual Governo.

A carga tributária é distribuída de forma igualitária entre a população, ou seja, está de acordo com a ocupação e remuneração das classes sociais. O povo de Vermonde possui a opinião de que é dever de todo cidadão contribuir para a arrecadação de tributos.

A legislação do país é transparente e o Governo oferece a oportunidade de aconselhamento gratuito sobre assuntos judiciais e questões tributárias através de centros de informação à população. Além disso, as autoridades de Vermonde são muito focadas na prestação de serviço ao povo e muito interessadas em oferecer suporte aos cidadãos.

A população é bem informada sobre os gastos do Governo, na medida em que eles são regularmente divulgados, o que possibilita a todos saberem onde está sendo aplicado o dinheiro de seus tributos. Uma pesquisa realizada em novembro de 2012 demonstrou que 78\% da população entende que o dinheiro que gastam com tributos é utilizado de forma adequada pelo Governo. 
Além disso, apenas uma pequena parte da arrecadação tributária é desviada por políticos. De acordo com um índice de corrupção internacional Vermonde é um dos países com a menor taxa de corrupção do mundo.

Todos estes fatores acarretam muita confiança da população no país em que vivem.

\section{Instruções 3/4 - Grupo Baixa Confiança}

Vermonde é país onde nasceu e vive e que no último censo realizado em Janeiro de 2013 contatou-se uma população total de 16.336.000 habitantes. A taxa de desemprego encontra-se na média mundial.

Desde sua independência em 1849 o país se caracteriza por possuir pouca estabilidade política e um governo oligárquico, onde o poder está concentrado na mão de poucos. Raramente são realizados referendos para que os cidadãos de Vermonde expressem sua opinião sobre o conjunto de leis que estão sendo debatidas no Congresso.

O Governo possui uma má reputação perante o povo. Segundo pesquisas $70 \%$ da população não está satisfeita com o atual Governo.

A carga tributária não é distribuída de forma igualitária entre a população, ou seja, não está de acordo com a sua ocupação e remuneração. O povo de Vermonde possui a opinião de que não é dever de todo cidadão contribuir para a arrecadação de tributos.

A legislação do país não é transparente e não existem centros de informação que ofereçam aconselhamento gratuito à população sobre assuntos judiciais e questões tributárias. Além disso, as autoridades de Vermonde são pouco focadas na prestação de serviço ao povo e pouco interessadas em oferecer suporte aos cidadãos. 
A população é mal informada sobre os gastos do Governo, na medida em que eles não são regularmente divulgados, o que impossibilita a todos saber onde está sendo aplicado o dinheiro de seus tributos. Uma pesquisa realizada em novembro de 2012 demonstrou que $78 \%$ da população entende que o dinheiro que gastam com tributos não é utilizado de forma adequada pelo Governo.

Além disso, uma grande parte da arrecadação tributária é desviada por políticos. De acordo com um índice de corrupção internacional Vermonde é um dos países com a maior taxa de corrupção do mundo.

Todos estes fatores acarretam pouca confiança da população no país e em seus governantes.

\section{Instruções 4/4 - Grupo Muito Poder}

A fiscalização sobre sonegação fiscal em Vermonde é muito eficaz. Por causa da legislação fiscal é fácil para o governo fiscalizar seus cidadãos e empresas e com isso autuar os sonegadores.

O governo atribui um alto orçamento para a administração fiscal realizar fiscalizações e coibir a sonegação. Com os meios disponíveis é possível para a administração empregar inspetores fiscais muito qualificados. Além disso, a população considera que os auditores fiscais possuem uma presença constante no cotidiano do país.

A chance de ser fiscalizado em Vermonde é considerada alta. Em outras palavras, as pessoas e empresas são fiscalizadas com frequência. Portanto, a maior parte das práticas de sonegação fiscal é detectada. Além disso, as multas por sonegação de impostos são consideradas altas. Quando os sonegadores de impostos são detectados, eles têm de antecipar o pagamento de severas multas. A administração fiscal não é benevolente com os sonegadores. 
Todos esses fatores fazem com que os cidadãos de Vermonde avaliem o seu Governo como muito capaz de controlar a sonegação fiscal.

\section{Instruções 4/4 - Grupo Pouco Poder}

A fiscalização sobre sonegação fiscal em Vermonde não é muito eficaz. Por causa da complexa legislação fiscal é difícil para o governo realizar fiscalizações em seus cidadãos e empresas e com isso autuar os sonegadores.

O governo atribui um baixo orçamento para a administração fiscal realizar fiscalizações e coibir a sonegação. Com os meios disponíveis é impossível para a administração empregar inspetores fiscais muito qualificados. Além disso, a população considera os auditores fiscais ausentes no cotidiano do país.

A chance de ser fiscalizado em Vermonde é considerada baixa, em outras palavras, as pessoas e empresas não são fiscalizadas com frequência. Portanto, a maior parte das práticas de sonegação fiscal não é detectada. Além disso, as multas por sonegação de impostos são consideradas baixas em Vermonde. Quando os sonegadores de tributos são detectados, eles não precisam antecipar o pagamento de severas multas. A administração fiscal é benevolente com os sonegadores.

Todos esses fatores fazem com que os cidadãos de Vermonde avaliem o seu Governo como pouco capaz de controlar a sonegação fiscal.

\section{QUESTIONÁRIO DE ADERÊNCIA (ESCALA LIKERT DE 5 PONTOS)}

1 - Pela descrição anterior é possível concluir que Vermonde é um país onde os cidadãos confiam no seu Governo? 
2 - Pela descrição anterior é possível concluir que Vermonde é um país onde o Governo tem muita força fiscalizatória em face dos contribuintes?

\section{Períodos}

\begin{tabular}{|l|l|}
\hline \multicolumn{1}{|c|}{ PERÍODO } & \multicolumn{1}{c|}{ INFORMAÇÃO } \\
\hline 10 Período & $\begin{array}{l}\text { - Considere as informações até aqui recebidas e informe o valor que pagará de } \\
\text { tributos neste PERÍODO: }\end{array}$ \\
\hline 2o Período & $\begin{array}{l}\text { - Considere as informações até aqui recebidas e informe o valor que pagará de } \\
\text { tributos neste PERÍODO: }\end{array}$ \\
\hline 3o Período & $\begin{array}{l}\text { - Considere as informações até aqui recebidas e informe o valor que pagará de } \\
\text { tributos neste PERÍODO: }\end{array}$ \\
\hline 4o Período & $\begin{array}{l}\text { - Considere as informações até aqui recebidas e informe o valor que pagará de } \\
\text { tributos neste PERÍODO: }\end{array}$ \\
\hline 5o Período & $\begin{array}{l}\text { - Considere as informações até aqui recebidas e informe o valor que pagará de } \\
\text { tributos neste PERÍODO: }\end{array}$ \\
\hline 6o Período & $\begin{array}{l}\text { - Considere as informações até aqui recebidas e informe o valor que pagará de } \\
\text { tributos neste PERÍODO: }\end{array}$ \\
\hline 70 Período & $\begin{array}{l}\text { - Considere as informações até aqui recebidas e informe o valor que pagará de } \\
\text { tributos neste PERÍODO: }\end{array}$ \\
\hline 80 Período & $\begin{array}{l}\text { - Considere as informações até aqui recebidas e informe o valor que pagará de } \\
\text { tributos neste PERÍODO: }\end{array}$ \\
\hline 9o Período & $\begin{array}{l}\text { - Considere as informações até aqui recebidas e informe o valor que pagará de } \\
\text { tributos neste PERÍODO: }\end{array}$ \\
\hline 10 Período & $\begin{array}{l}\text { - Considere as informações até aqui recebidas e informe o valor que pagará de } \\
\text { tributos neste PERÍODO: }\end{array}$ \\
\hline
\end{tabular}

\section{QUESTIONÁRIO (ESCALA LIKERT DE 5 PONTOS)}

Considerando as informações recebidas sobre Vermonde, país que nasceu e reside, responda o questionário abaixo:

Q1- Pagar tributos é a coisa certa a se fazer? 
Q2- Pagar tributos é uma responsabilidade que deveria ser aceita voluntariamente por todos os cidadãos de Vermonde?

Q3- Eu me sinto moralmente obrigado a pagar tributos em Vermonde.

Q4- Pagar meus tributos representa vantagem para todos os cidadãos de Vermonde?

Q5- Eu acredito que pagar tributos é uma ajuda para que o Governo de Vermonde faça as coisas necessárias para a população.

Q6- Geralmente eu pago meus tributos com boa vontade.

Q7- Eu não me sinto bem ao pagar de tributos em Vermonde.

Q8- Aceito a responsabilidade de pagar minha parte de tributos.

Q9- Se você não cooperar com as autoridades fiscais de Vermonde, eles serão rigorosos com você?

Q10- As autoridades fiscais de Vermonde estão mais interessadas em encontrar algo errado você que tenha feito do que ajudá-lo a fazer a coisa certa?

Q11- É recomendável se manter distante das autoridades fiscais de Vermonde?

Q12- É impossível satisfazer as autoridades fiscais completamente.

Q13- Caso você seja pego sonegando impostos as autoridades fiscais sempre the verão como sonegador. 
Q14- Como uma sociedade, nós precisamos de mais pessoas dispostas a enfrentar as autoridades fiscais. 


\title{
APÊNDICE D
}

\section{REPRODUÇÃO EM TEXTO DO EXPERIMENTO}

\author{
Instruções 1/4
}

A seguir você receberá informações acerca do país em que vive. Imagine fortemente que realmente vive neste país e faça seus apontamentos de acordo com esta premissa.

A cada nova etapa você poderá receber uma informação e, então, deverá apontar pelo valor a ser pago de imposto que optará durante o período. Ao final, responda o questionário e o experimento será encerrado.

\section{Instruções 2/4}

- Você é cidadão de Vermonde e está empregado. A legislação local determina que a cada ano declare e pague seu imposto de renda de acordo com exigido;

- Não há retenção de tributos na fonte em Vermonde. Vale dizer que a opção em cumprir integralmente a determinação da lei sobre o montante a ser recolhido compete exclusivamente a você, sujeitando-se as fiscalizações por parte do Governo;

- $\quad$ Antes de declarar e pagar seu imposto de renda você poderá receber informações sobre questões de naturezas diversas;

- Seu rendimento por período é de $\$ 5.200,00$ (em moeda corrente de Vermonde);

- $\quad$ A alíquota efetiva do imposto de renda prevista em lei é de $15 \%$;

- Você deverá decidir qual o montante de tributos irá pagar até o limite da carga tributária prevista em lei. Em outras palavras decidirá entre pagar em cada período de \$ 0 até $\$ 780,00 ;$ 
- Caso você seja autuado por sonegação fiscal, ou seja, quando não recolher o valor integral do tributo conforme previsto em lei, a multa será de $50 \%$ do valor da sonegação;

- $\quad$ o período de prescrição e decadência é de 03 (três anos). Isso significa que caso você seja fiscalizado o Governo irá avaliar os 03 (três) últimos períodos buscando eventual recolhimento inferior ao percentual determinado pela lei;

- $\quad$ O valor que lhe restará, portanto, é o valor de seu rendimento subtraído do valor dos tributos pagos e, se o caso, do valor da multa por sonegação fiscal.

\section{Instruções 3/4}

Vermonde é país onde nasceu e vive e que no último censo realizado em Janeiro de 2013 contatou-se uma população total de 16.336 .000 habitantes. A taxa de desemprego encontra-se na média mundial.

Desde sua independência em 1849 o país se caracteriza por possuir pouca estabilidade política e um governo oligárquico, onde o poder está concentrado na mão de poucos. Raramente são realizados referendos para que os cidadãos de Vermonde expressem sua opinião sobre o conjunto de leis que estão sendo debatidas no Congresso.

O Governo possui uma má reputação perante o povo. Segundo pesquisas $70 \%$ da população não está satisfeita com o atual Governo.

A carga tributária não é distribuída de forma igualitária entre a população, ou seja, não está de acordo com a sua ocupação e remuneração. O povo de Vermonde possui a opinião de que não é dever de todo cidadão contribuir para a arrecadação de tributos. 
A legislação do país não é transparente e não existem centros de informação que ofereçam aconselhamento gratuito à população sobre assuntos judiciais e questões tributárias. Além disso, as autoridades de Vermonde são pouco focadas na prestação de serviço ao povo e pouco interessadas em oferecer suporte aos cidadãos.

A população é mal informada sobre os gastos do Governo, na medida em que eles não são regularmente divulgados, o que impossibilita a todos saber onde está sendo aplicado o dinheiro de seus tributos. Uma pesquisa realizada em novembro de 2012 demonstrou que $78 \%$ da população entende que o dinheiro que gastam com tributos não é utilizado de forma adequada pelo Governo.

Além disso, uma grande parte da arrecadação tributária é desviada por políticos. De acordo com um índice de corrupção internacional Vermonde é um dos países com a maior taxa de corrupção do mundo.

Todos estes fatores acarretam pouca confiança da população no país e em seus governantes.

\section{Instruções 4/4}

A fiscalização sobre sonegação fiscal em Vermonde não é muito eficaz. Por causa da complexa legislação fiscal é difícil para o governo realizar fiscalizações em seus cidadãos e empresas e com isso autuar os sonegadores.

O governo atribui um baixo orçamento para a administração fiscal realizar fiscalizações e coibir a sonegação. Com os meios disponíveis é impossível para a administração empregar inspetores fiscais muito qualificados. Além disso, a população considera os auditores fiscais ausentes no cotidiano do país. 
A chance de ser fiscalizado em Vermonde é considerada baixa, em outras palavras, as pessoas e empresas não são fiscalizadas com frequência. Portanto, a maior parte das práticas de sonegação fiscal não é detectada. Além disso, as multas por sonegação de impostos são consideradas baixas em Vermonde. Quando os sonegadores de tributos são detectados, eles não precisam antecipar o pagamento de severas multas. A administração fiscal é benevolente com os sonegadores.

Todos esses fatores fazem com que os cidadãos de Vermonde avaliem o seu Governo como pouco capaz de controlar a sonegação fiscal.

\section{Períodos - Grupo Recompensas}

\begin{tabular}{|c|c|}
\hline PERÍODO & INFORMAÇÃO \\
\hline 10 Período & $\begin{array}{l}\text { onsidere as informações até aqui recebidas e informe o valor que pagará de } \\
\text { butos neste PERÍODO: }\end{array}$ \\
\hline 20 Período & $\begin{array}{l}\text { - O Governo promulgou uma lei que } 20 \% \text { do imposto de renda que recolher irá } \\
\text { compor um fundo de investimento em melhorias no bairro em que reside. } \\
\text { Pelas ruas do seu bairro você nota obras de melhorias financiadas por este } \\
\text { fundo. } \\
\text { - Considere as informações até aqui recebidas e informe o valor que pagará de } \\
\text { tributos neste PERÍODO: }\end{array}$ \\
\hline 30 $\mathrm{Pe}$ & $\begin{array}{l}\text { ções até aqui recebidas e informe o valor que pagará de } \\
\text { D: }\end{array}$ \\
\hline & $\begin{array}{l}\text { - O Governo lançou um programa de incentivo aos bons contribuintes. O } \\
\text { Programa consiste na restituição de } 10 \% \text { do valor do imposto de renda } \\
\text { recolhido pelo contribuinte caso ele não possua nenhuma infração fiscal ou } \\
\text { recolhimento com atraso nos últimos } 05 \text { anos. } \\
\text { - Considere as informações até aqui recebidas e informe o valor que pagará de } \\
\text { tributos neste PERÍODO: }\end{array}$ \\
\hline 5o Período & $\begin{array}{l}\text { onsidere as informações até aqui recebidas e informe o valor que pagará de } \\
\text { utos neste PERÍODO: }\end{array}$ \\
\hline 60 Período & $\begin{array}{l}\text { - Considere as informações até aqui recebidas e informe o valor que pagará de } \\
\text { tributos neste PERÍODO: }\end{array}$ \\
\hline $70 \mathrm{P}$ & $\begin{array}{l}\text { - O Governo lançou um programa de premiação aos contribuintes. O programa } \\
\text { consiste em um fundo com } 1 \% \text { de todo o imposto de renda recolhido pelos }\end{array}$ \\
\hline
\end{tabular}




\begin{tabular}{|c|c|}
\hline & $\begin{array}{l}\text { cidadãos e a realização de diversos sorteios entre os contribuintes que não } \\
\text { apresentem débitos perante a Receita Federal. No primeiro sorteio, dentre } \\
\text { outras pessoas, você foi contemplado, ganhando } R \$ 50,00 \text {. } \\
\text { - Considere as informações até aqui recebidas e informe o valor que pagará de } \\
\text { tributos neste PERÍODO: }\end{array}$ \\
\hline $80 \mathrm{Pe}$ & $\begin{array}{l}\text { - Considere as informações até aqui recebidas e informe o valor que pagará de } \\
\text { tributos neste PERÍODO: }\end{array}$ \\
\hline 90 $\mathrm{P}$ & $\begin{array}{l}\text { - Você está interessado na compra de um imóvel e os Bancos públicos } \\
\text { anunciaram que os contribuintes que não sonegarem tributos terão linha } \\
\text { especial de crédito imobiliário, com redução de até um ponto percentual ao } \\
\text { ano da taxa de financiamento (lembrando que as taxas giram em torno de } 10 \% \\
\text { ao ano mais encargos). } \\
\text { - Considere as informações até aqui recebidas e informe o valor que pagará de } \\
\text { tributos neste PERÍODO: }\end{array}$ \\
\hline 10 Período & $\begin{array}{l}\text { - Considere as informações até aqui recebidas e informe o valor que pagará de } \\
\text { tributos neste PERÍODO: }\end{array}$ \\
\hline
\end{tabular}

\section{Períodos - Grupo Punições}

\begin{tabular}{|c|c|c|}
\hline PERÍODO & $\begin{array}{l}\text { INFORMAÇÃO EM CASO DE } \\
\text { SONEGAÇÃO }\end{array}$ & $\begin{array}{l}\text { INFORMAÇÃO EM CASO DE } \\
\text { OBSERVÂNCIA TOTAL }\end{array}$ \\
\hline 10 Período & $\begin{array}{l}\text { - Considere as informações até aqui } \\
\text { recebidas e informe o valor que } \\
\text { pagará de tributos neste PERÍODO: }\end{array}$ & $\begin{array}{l}\text { - Considere as informações até aqui } \\
\text { recebidas e informe o valor que } \\
\text { pagará de tributos neste PERÍODO: }\end{array}$ \\
\hline $20 \mathrm{P}$ & $\begin{array}{l}\text { - Atenção você caiu na malha fina e } \\
\text { suas declarações anteriores foram } \\
\text { fiscalizadas. Em razão deste } \\
\text { procedimento fiscal você foi multado } \\
\text { em _- } \\
\text { - Considere as informações até aqui } \\
\text { recebidas e informe o valor que } \\
\text { pagará de tributos neste PERíODO: }\end{array}$ & $\begin{array}{l}\text { - Atenção você caiu na malha fina e } \\
\text { suas declarações anteriores foram } \\
\text { fiscalizadas. Todavia, uma vez que não } \\
\text { sonegou tributos você não foi } \\
\text { multado. } \\
\text { - Considere as informações até aqui } \\
\text { recebidas e informe o valor que } \\
\text { pagará de tributos neste PERíoDo: }\end{array}$ \\
\hline 3o Período & $\begin{array}{l}\text { - Considere as informações até aqui } \\
\text { recebidas e informe o valor que } \\
\text { pagará de tributos neste PERÍODO: }\end{array}$ & $\begin{array}{l}\text { - Considere as informações até aqui } \\
\text { recebidas e informe o valor que } \\
\text { pagará de tributos neste PERÍODO: }\end{array}$ \\
\hline
\end{tabular}




\begin{tabular}{|c|c|c|}
\hline 40 $\mathrm{Pe}$ & $\begin{array}{l}\text { - Atenção você caiu na malha fina e } \\
\text { suas declarações anteriores foram } \\
\text { fiscalizadas. Em razão deste } \\
\text { procedimento fiscal você foi multado } \\
\text { em_- } \\
\text { - Considere as informações até aqui } \\
\text { recebidas e informe o valor que } \\
\text { pagará de tributos neste PERíODo: }\end{array}$ & $\begin{array}{l}\text { - Atenção você caiu na malha fina e } \\
\text { suas declarações anteriores foram } \\
\text { fiscalizadas. Todavia, uma vez que não } \\
\text { sonegou tributos você não foi } \\
\text { multado. } \\
\text { - Considere as informações até aqui } \\
\text { recebidas e informe o valor que } \\
\text { pagará de tributos neste PERíODo: }\end{array}$ \\
\hline 5o Período & $\begin{array}{l}\text { - Considere as informações até aqui } \\
\text { recebidas e informe o valor que } \\
\text { pagará de tributos neste PERÍODO: }\end{array}$ & $\begin{array}{l}\text { - Considere as informações até aqui } \\
\text { recebidas e informe o valor que } \\
\text { pagará de tributos neste PERíODO: }\end{array}$ \\
\hline 601 & $\begin{array}{l}\text { - Considere as informações até aqui } \\
\text { recebidas e informe o valor que } \\
\text { pagará de tributos neste PERÍODO: }\end{array}$ & $\begin{array}{l}\text { - Considere as informações até aqui } \\
\text { recebidas e informe o valor que } \\
\text { pagará de tributos neste PERíODO: }\end{array}$ \\
\hline & $\begin{array}{l}\text { - Atenção você caiu na malha fina e } \\
\text { suas declarações anteriores foram } \\
\text { fiscalizadas. Em razão deste } \\
\text { procedimento fiscal você foi multado } \\
\text { em_- } \\
\text { - Considere as informações até aqui } \\
\text { recebidas e informe o valor que } \\
\text { pagará de tributos neste PERíODo: }\end{array}$ & $\begin{array}{l}\text { - Atenção você caiu na malha fina e } \\
\text { suas declarações anteriores foram } \\
\text { fiscalizadas. Todavia, uma vez que não } \\
\text { sonegou tributos você não foi } \\
\text { multado. } \\
\text { - Considere as informações até aqui } \\
\text { recebidas e informe o valor que } \\
\text { pagará de tributos neste PERíoDO: }\end{array}$ \\
\hline 8 & $\begin{array}{l}\text { - Considere as informaçõe } \\
\text { recebidas e informe o } \\
\text { pagará de tributos neste PE }\end{array}$ & $\begin{array}{l}\text { - Considere as informações até aqui } \\
\text { recebidas e informe o valor que } \\
\text { pagará de tributos neste PERÍODO: }\end{array}$ \\
\hline 9 & $\begin{array}{l}\text { - Atenção você caiu na malha fina e } \\
\text { suas declarações anteriores foram } \\
\text { fiscalizadas. Em razão deste } \\
\text { procedimento fiscal você foi multado } \\
\text { em_- } \\
\text { - Considere as informações até aqui } \\
\text { recebidas e informe o valor que } \\
\text { pagará de tributos neste PERíODo: }\end{array}$ & $\begin{array}{l}\text { - Atenção você caiu na malha fina e } \\
\text { suas declarações anteriores foram } \\
\text { fiscalizadas. Todavia, uma vez que não } \\
\text { sonegou tributos você não foi } \\
\text { multado. } \\
\text { - Considere as informações até aqui } \\
\text { recebidas e informe o valor que } \\
\text { pagará de tributos neste PERíODO: }\end{array}$ \\
\hline 10 Período & $\begin{array}{l}\text { - Considere as informações até aqui } \\
\text { recebidas e informe o valor que } \\
\text { pagará de tributos neste PERÍODO: }\end{array}$ & $\begin{array}{l}\text { - Considere as informações até aqui } \\
\text { recebidas e informe o valor que } \\
\text { pagará de tributos neste PERÍODO: }\end{array}$ \\
\hline
\end{tabular}




\section{Períodos - Grupo Controle}

\begin{tabular}{|c|c|}
\hline PERÍODO & INFORMAÇÃO \\
\hline 10 Período & $\begin{array}{l}\text { - Considere as informações até aqui recebidas e informe o valor que pagará de } \\
\text { tributos neste PERÍODO: }\end{array}$ \\
\hline 20 Período & $\begin{array}{l}\text { - Considere as informações até aqui recebidas e informe o valor que pagará de } \\
\text { tributos neste PERÍODO: }\end{array}$ \\
\hline 3o Período & $\begin{array}{l}\text { - Considere as informações até aqui recebidas e informe o valor que pagará de } \\
\text { tributos neste PERÍODO: }\end{array}$ \\
\hline 40 $\mathrm{Pe}$ & $\begin{array}{l}\text { - Considere as informações até aqui recebidas e informe o valor que pagará de } \\
\text { tributos neste PERÍODO: }\end{array}$ \\
\hline 5o Período & $\begin{array}{l}\text { s informações até aqui recebidas e informe o valor que pagará de } \\
\text { PERÍODO: }\end{array}$ \\
\hline 60 Período & $\begin{array}{l}\text { - Considere as informações até aqui recebidas e informe o valor que pagará de } \\
\text { tributos neste PERÍODO: }\end{array}$ \\
\hline 70 Período & $\begin{array}{l}\text { - Considere as informações até aqui recebidas e informe o valor que pagará de } \\
\text { tributos neste PERÍODO: }\end{array}$ \\
\hline 80 Período & $\begin{array}{l}\text { - Considere as informações até aqui recebidas e informe o valor que pagará de } \\
\text { tributos neste PERÍODO: }\end{array}$ \\
\hline 90 Período & $\begin{array}{l}\text { - Considere as informações até aqui recebidas e informe o valor que pagará de } \\
\text { tributos neste PERÍODO: }\end{array}$ \\
\hline 10 Período & $\begin{array}{l}\text { - Considere as informações até aqui recebidas e informe o valor que pagará de } \\
\text { tributos neste PERÍODO: }\end{array}$ \\
\hline
\end{tabular}

